\title{
POLLUTION HAVEN HYPOTHESIS OR FACTOR ENDOWMENT HYPOTHESIS: \\ THEORY AND EMPIRICAL EXAMINATION FOR THE US AND CHINA
}

\section{Umed Temurshoev}
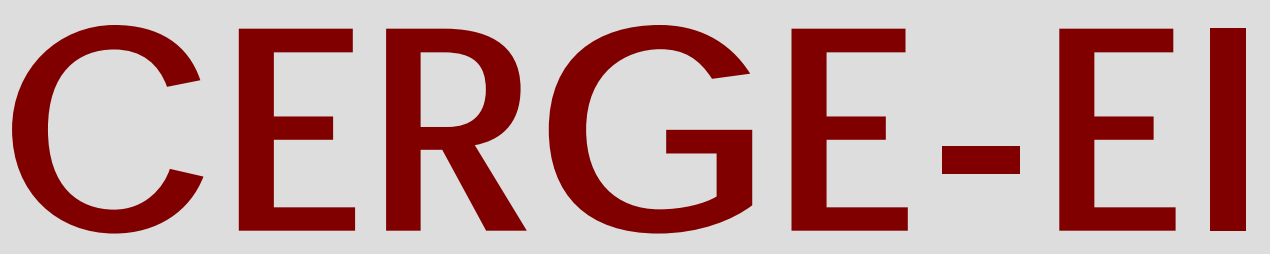

Charles University Centerfor Ec onomic Research and Graduate Educ ation Academy of Sciences of the Czech Republic Ec onomic Institute 


\title{
Working Paper Series 292 (ISSN 1211-3298)
}

\section{Pollution Haven Hypothesis or Factor Endowment Hypothesis: Theory and Empirical Examination for the US and China}

\author{
Umed Temurshoev
}

CERGE-EI

Prague, March 2006 
ISBN 80-7343-087-8 (Univerzita Karlova v Praze, CERGE)

ISBN 80-7344-076-8 (Národohospodářský ústav AV ČR, Praha) 


\title{
Pollution Haven Hypothesis or Factor Endowment Hypothesis: Theory and Empirical Examination for the US and China*
}

\author{
Umed Temurshoev $\dagger$
}

CERGE-EI**

\begin{abstract}
This paper examines how free international trade affects the environment in the developed and less developed worlds. Using input-output techniques, tests of the pollution haven hypothesis $(\mathrm{PHH})$ and the factor endowment hypothesis (FEH) for the US and China were empirically carried out. We found that China gains and the US lose in terms of $\mathrm{CO} 2, \mathrm{SO} 2$ and NOx emissions from increased trade, and the US is not exporting capital intensive goods. Thus both the PHH and the FEH are rejected, which implies that explaining the trade of pollutants remains an unresolved puzzle.
\end{abstract}

\begin{abstract}
Abstrakt
Tato studie zkoumá, jak volný mezinárodní obchod ovlivňuje životní prostředí v rozvinutých a méně rozvinutých zemích světa. Testy hypotéz znečišt'ovacího ráje $(\mathrm{PHH})$ a faktorového vybavení (FEH) byly provedeny empiricky pro USA a Č́nu pomocí inputoutput technik. Zjistili jsme, že z rostoucího obchodu získává Čína, kdežto USA ztrácí co se týče emisí CO2, SO2 a NOx. Kromě toho USA neexportuje kapitálově náročné statky. Tím pádem jsme obě hypotézy zamítli, což mimo jiné znamená, že mezinárodní obchod s emisemi zůstává nevyřešenou hádankou.
\end{abstract}

Keywords: International trade, Environment, Pollution haven, Factor endowment, Inputoutput analysis

JEL Classification Codes: F18, Q32, D57

\footnotetext{
* I am indebted to Prof. Erik Dietzenbacher for his very helpful comments and suggestions. I am grateful to Mingtai Fan, Michael Lahr and Kakali Mukhopadhyay for providing necessary data. I thank Lawrence Smith for editing the paper. The work was supported by the CERGE-EI / World Bank Fellowship. All errors are mine.

**A joint workplace of the Center for Economic Research and Graduate Education, Charles University, and the Economics Institute of the Academy of Sciences of the Czech Republic.

Address: CERGE-EI, P.O. Box 882, Politických vězňů 7, Prague 1, 11 21, Czech Republic.

Email: umed.temurshoev@cerge-ei.cz

$\dagger$ Faculty of Economics, University of Groningen, SOM Research School, PO Box 800, 9700 AV

Groningen, The Netherlands. E-mail: u.temurshoev@rug.nl
} 


\section{Introduction}

The world economy in the last decade has been characterized by liberalization of trade, which question consequences on the world environment. The debate on the effects of international trade on environmental quality began with the negotiations over the North American Free Trade Agreement (NAFTA), the Uruguay round of the General Agreement on Tariffs and Trade (GATT) negotiations, and the formation of the World Trade Organization (WTO). This debate gained much importance due to the Kyoto and Montreal Protocols and discussions on the impact of greenhouse gas emissions on global warming and climate change.

Recent economic literature on the relationship between international trade, economic growth and the environment is more positive, i.e. it seeks to empirically test hypotheses about how growth or trade effects the environment, which is crucial for resolving current policy debates. There are two competing hypotheses that predict how international trade affects the environment.

The pollution haven hypothesis $(\mathrm{PHH})$ predicts that, under free trade, multinational firms will relocate the production of their pollution-intensive goods to developing countries, taking advantage of the low environment monitoring in these countries. Over time, developing countries will develop a comparative advantage in pollution-intensive industries and become "havens" for the world's polluting industries. Thus developed countries are expected to benefit in terms of environmental quality from trade, while developing countries will lose.

The factor endowment hypothesis (FEH), on the contrary, asserts that it is not the differences in pollution policy, but the differences in endowments or technology that determine trade. In particular, it predicts that the capital abundant country exports the capital-intensive (dirty) goods, which stimulates its production, thus raising pollution in the capital abundant country. Conversely, pollution falls in the capital-scarce country as a result of contraction of the production of pollution-intensive goods, since there is no comparative advantage of producing polluting goods in the developing world. So overall, the effects of trade on the environment both locally and globally depend on the distribution of comparative advantages across countries. It is important to note that 
comparative advantage is determined jointly by differences in pollution policy and among other influences by differences in factor endowments. ${ }^{1}$

From the review of literature below, it will become clear that the existing empirical evidence on the PHH is quite ambiguous, while that on the FEH seems to be largely lacking. Thus it seems important to test the hypotheses in the case of developed and developing countries simultaneously; thus the analysis is carried out for the US and China. The reason for choosing these countries is twofold. First, the US and China are historically the largest emitters of the carbon dioxide $\left(\mathrm{CO}_{2}\right)$, which is the most prominent greenhouse gas $(76 \%)$ in the earth's atmosphere. According to International Energy Agency (IEA) data, in 1997 the US and China were responsible for $24 \%$ and $14 \%$ of the total world $\mathrm{CO}_{2}$ emissions from fuel combustion, respectively, while Russia, the third country in this ranking, emitted only $6 \%$ of the world total carbon emissions. Second, the chosen countries are good examples of developed and developing states. Since our concern are mainly the consequences on local environments of trade between rich and poor countries, the US and China are an appropriate choice for the empirical examination of the hypotheses mentioned above.

This study focuses on the following main issues. Do countries benefit from international trade in terms of pollution emissions? Who gains (loses) more: developed or developing countries? Here, especially, the consequences of US-China trade on their environments are of particular interest. What is the tendency of these benefits (losses) over time? Do capital-abundant countries export more pollution-intensive goods and do developing countries export less pollution-intensive goods? The answers to these questions then shed light on whether the PHH or the FEH is in line with the outcomes that are based on the real data.

Econometric tests of the $\mathrm{PHH}$ face problems of endogeneity of explanatory variables, tests run only for a single country, and inadequate and poor quality data for most developing countries. In particular, taking all this into consideration, Taylor (2004; p.22) states: "In fact, no study in the literature provides a compelling many-country test

\footnotetext{
${ }^{1}$ For other sources of comparative advantage, see, for example, Chichilnisky (1994) arguing that the illdefined property rights on the common pool resource result in the comparative advantage of poor countries in the polluting (resource-intensive) sector, or Di Maria and Smulders (2004) suggesting that the differences in investment-innovation opportunities and distortions between the innovating rich countries and imitating poorer countries gives a source of comparative advantage in pollution-intensive goods.
} 
of the PHH, and I know of no theory paper that details what such a test would look like". We think that one of the methods that can potentially fill this gap in the empirical literature is the use of input-output (IO) techniques. The advantage is that IO analysis does not rely on the availability of long time series of emissions and takes into full account the interdependencies of production sectors in the economy, which is crucial for energy analysis (see e.g. Wilting, 1996). Using IO techniques, testing the PHH and the $\mathrm{FEH}$ with respect to the gains and/or losses of countries from trade in terms of emissions and their developments over time are central in this paper.

The paper proceeds as follows. In Section 2 we review a sample of theoretical and empirical literature on the relationship between trade, growth and the environment. In particular, the literature review shows that empirical evidence on the $\mathrm{PHH}$ is controversial. Section 3 discusses briefly the theory behind the PHH and the FEH. The methodology, based on input-output techniques, is presented in Section 4. The PHH and the FEH in the model framework are discussed in Section 5. Section 6 describes the data sources and data preparation. The empirical tests for the US and China are carried out in Section 7, for major greenhouse gases of carbon, sulphur and nitrogen dioxides. Section 8 represents a summary of the findings and contains some concluding remarks.

\section{Review of a sample of literature}

Although there is a huge amount of theoretical and empirical work on the relationship between international trade, growth and the environment, we will discuss only a part of it in this section. ${ }^{2}$

Copeland and Taylor (2004) is an important contribution to this literature. Besides modeling the relationship between income and the environment (the so called Environmental Kuznets Curve) and shedding light on the debate over environmental and trade policies substitutability (i.e. the main concern is that trade agreements reduce trade policy instruments, thus governments seeking to protect local firms will weaken environmental policy), the authors provide a solid explanation of the $\mathrm{PHH}$ and the FEH

\footnotetext{
${ }^{2}$ For a comprehensive review of this literature see, for example, Copeland and Taylor (2004).
} 
in the two region, two goods model. Taking the endogeneity problem in previous empirical work into account, the first conclusion of Copeland and Taylor is that trade and investments are influenced by pollution regulations. Secondly, they conclude that incomes affect environmental quality in a positive way, which suggests that in analyzing the effects of growth and trade on the environment, one should not just associate growth with increased environmental damage, but also consider the beneficial effects on environmental policy. And lastly, the authors note that there is little convincing evidence to support the PHH. Is free trade good or bad for the environment, they claim, requires more empirical research that among other things should consider more pollutants. ${ }^{3}$

To highlight what has been done in the empirical examination of the relationship between trade, growth and the environment we review the empirical literature next, which we divide into three categories.

The first branch of literature on the empirical testing of these issues examined relatively simple statistical exercises on trends of "dirty goods" production, consumption, or trade, and largely lacked a sound theoretical background. Authors first classified industries into dirty and clean industries on the basis of their emission intensity (emission per US dollars (USD) of output), toxic intensity (physical releases per USD of output), or pollution abatement costs as a fraction of value-added. In some cases they employed regression analysis where income differences, measures of openness and income growth rate were used as explanatory variables. Among other papers, this literature includes Low and Yeats (1992), Lucas et al. (1992), Mani and Wheeler (1997), Xu (1999).

Low and Yeats (1992) find that the share of "dirty" industries in exports from developed countries fell from $20 \%$ to $16 \%$ over the $1965-1988$ period, while the share of dirty goods in exports from poor countries rose. The last numbers are different by regions: in West Asia the percent rises from 9\% to 13\%, in Eastern Europe from $21 \%$ to $28 \%$, in Latin America from $17 \%$ to $21 \%$, and in South-East Asia the share of dirty goods exports in total exports is flat at $11 \%$.

Lucas et al. (1992) empirically examine how the structure of manufacturing production varies, both across countries and over time, in relation to the toxic emissions

\footnotetext{
${ }^{3}$ See also Copeland and Taylor (1995) that deals with the effects of trade and environmental policy on trade flows, pollution levels, and welfare.
} 
of component industries. They find evidence for an inverse $\mathrm{U}$-shape relationship between industrial pollution intensity and income. It is also concluded that the poorest economies have the highest toxic intensity growth, and pollution intensity has grown most rapidly in relatively closed developing economies, while for more open countries the opposite is true. The result is opposite to the PHH prediction, since under the PHH relatively closed poor economies should have a cleaner mix of industries, and it is trade that makes them dirtier.

Mani and Wheeler (1997) examine the PHH using international data on industrial production, trade and environmental regulation for the period 1960-1995. Their crosscountry analysis gives a result that is consistent with the PHH. They find that pollutionintensive output as a percentage of manufacturing has fallen consistently in the OECD economies and risen steadily in the developing world. Besides, it is revealed that periods of rapid increase in net exports of pollution-intensive product coincide with periods of rapid increase in the costs of pollution abatement in the OECD countries.

$\mathrm{Xu}$ (1999) examines whether stringent environmental standards reduce the international competitiveness of environmentally sensitive goods (ESGs - goods with high levels of abatement expenditures per unit of output), using data for 34 countries for the period of 1965-95 that accounted for nearly 80\% of world exports of ESGs in 1995. The main empirical finding of the paper is that despite the introduction of stringent environmental standards in most of the developed countries in the 1970s and 1980s, export performance of ESGs ("dirty" goods) for most countries remained unchanged between the 1960s and 1990s.

We should note the following concerning the first group of empirical research. Firstly, the trend of dirty goods production is not necessarily a good measure of pollution levels. Over time the technology of production of dirty goods changes as well, thus an increase in dirty goods production is associated both with more and less pollution levels. And secondly, this literature lacks theoretical concern that resulted in not taking into account many other factors, which potentially affect pollution, limiting the analysis only to income levels as a major determinant of the change in trade patterns.

The second branch of empirical literature focus on the effect of stringency of environmental policy on trade flows, foreign direct investment flows, or plant location 
choices. These studies can be interpreted as a test of the PHH. And several of these studies attempt to estimate and then add up the so-called scale, composition and technique effects arising from trade liberalization (see below for details ) These studies can be divided into groups that are consistent with the time of research as well. The earlier studies concluded that there is little or no effect of differences in environmental policy on trade or investments flows. The second wave of these studies, accounting for endogeneity of pollution policy and unobservable industry- or country- specific variables, ended up with a complete reverse conclusion, i.e. differences in environmental regulation do affect trade and investments flows. In particular, we should note Tobey (1990), Grossman and Krueger (1993), Levinson and Taylor (2001), Antweiler et al. (2001), Dean (2002).

Grossman and Krueger (1993) is the first study that introduced the notion of scale, composition and technique effects. The authors argue that trade liberalization generally will affect the environment by expanding the scale of economic activity, by changing the composition of economic activity, and by bringing about a change in the technique of production. On the basis of their estimates, they conclude that any income gain created by NAFTA would lead to lower pollution in Mexico. And combining the evidence on scale, composition, and technique effects, the authors conclude that trade liberalization alone via NAFTA should be good for the Mexican environment, but if NAFTA led to increase capital accumulation, then the consequences are not quite clear.

Atweiler et al. (2001) develop a theoretical model, in which trade's impact is separated into scale, technique and composition effects, and then estimate and add up these effects using data on sulfur dioxide concentrations. Both the $\mathrm{PHH}$ and the FEH predict that openness of trade will change the composition of output in a way that depends on a nation's comparative advantage. In their estimation to account for this fact, the authors use the interaction of openness with relative income per capita (PHH) and relative capital to labor ratio $(\mathrm{FEH})$. Their estimated effect is quite small indicating that the PHH and the FEH tend to roughly offset each other. That is rich countries are capital abundant, which leads them to become dirtier with trade, but they also have stricter environmental policy which leads to a comparative advantage in clean goods. Thus a small net effect is equivalent to the offsetting motives discussed above. Their estimates of 
the scale and technique elasticities show that a $1 \%$ increase in both output and income due to free trade will decrease pollution concentrations by approximately $1 \%$. Summing up this with composition effects the authors conclude that free trade is good for the environment.

Dean (2002) comes up with a simultaneous equations system determining growth of income and growth of environmental damage, where the supply of clean environment is endogenous. The model describes the effect of trade liberalization on the growth of environmental damage through two mechanisms: direct effects via changes in relative prices and indirect effects via growth of income. The finding is then applied to Chinese provincial data on water pollution. The author finds that a fall in trade restriction (black market premium is a proxy) raises pollution directly, but since more free trade also raises income, via income growth the initial increase in pollution is mitigated. Overall the net effect of freer trade seems to be beneficial for the environment in China.

And finally, the third group of empirical literature on environmental damage of free trade includes research by specialists using input-output techniques as a main tool of study. Among others, these are Gay and Proops (1993), Wyckoff and Roop (1994), Hayami et al. (1997), Proops et al. (1999), Lenzen (2001), Machado et al. (2001), Dietzenbacher and Mukhopadhyay (2004), Mukhopadhyay and Forssell (2004).

Wyckoff and Roop (1994) argue that global warming policies based on reducing domestic greenhouse gas emissions ignore the importance of carbon embodied in international trade flows. The authors conclude that a significant amount (about 13\%) of total carbon emissions of the six largest OECD countries is embodied in manufacturing imports. For policy implications the paper suggests: expanding the accounting of carbon emissions to include the carbon embedded in imports of non-energy goods; taking care of technological change for certain industries that are the main source of the carbon embodied in imported manufactured products; and including as many countries as possible in the treatment of solving problems of trade and environmental quality.

Hayami et al. (1997) focus on environmental management issues, and suggest a systematic approach involving both technology choice and consumer preference for controlling the total emission of global warming gases. Carbon dioxide and other global warming gases are produced when fossil fuels are burnt, which takes place in both the 
production and consumption of goods and services. The authors discuss how IO analysis can be used to estimate the entire production and consumption of global warming gases conditional on production technology and consumer preferences.

Gay and Proops (1999) discuss carbon dioxide in the UK, and find that a huge amount of this emission (more than 60\%) is produced for the satisfaction of the indirect production demand for fossil fuels. This result justifies and strengthens the use of IO techniques, since the last method takes full account of indirect relationships among production sectors in the economy, thus is an ideal tool for the analysis of economic systems.

Machado et al. (2001) evaluate the effect of international trade on energy use and $\mathrm{CO}_{2}$ emissions in the Brazilian economy. They conclude that in 1995 total energy and total carbon emissions embodied in the export of non-energy goods are larger than the appropriate amounts embodied in the imports of non-energy goods, which confirms the PHH.

Dietzenbacher and Mukhopadhyay (2004) empirically examine the PHH for India as an example of a developing country. The authors calculate by how much pollution $\left(\mathrm{CO}_{2}, \mathrm{SO}_{2}\right.$ and $\left.\mathrm{NO}_{\mathrm{x}}\right)$ will increase if exports are raised by one billion rupees, using the actual share of each commodity in total exports. This is then compared with the reduction of pollution due to an increase of India's imports by one billion rupees, using the actual commodity shares in total imports in computation. Under different assumptions of pollution from fossil fuel combustion (production-generated pollution and consumptiongenerated pollution), the authors find that India gains considerably from extra trade, thus rejecting the PHH. The results show that over time this benefit only increased thus India has moved further away from being a pollution haven. This exercise is very similar to the test that was carried out by Leontief about fifty years ago in empirical examination of the Heckscher-Ohlin (HO) theory, where he compared the direct and indirect labor and capital requirements of one million US dollars of extra exports and imports (Leontief, 1953 1956). His surprising result was later to become known as the "Leontief paradox". In contrast to Leontief's work, the authors compare emissions of carbon, sulfur and nitrogen dioxides of extra imports and exports. The inconsistency of the empirical results and the theory (i.e. the PHH), led them to introduce the term "Green Leontief Paradox". 
Concluding the review of literature above, it is apparent that the empirical results are ambiguous for the PHH and largely lacking for the FEH, thus it seems important to test the hypotheses in the example of developed and developing countries simultaneously; our aim therefore is to empirically examine the PHH and the FEH in case of the US and China.

\section{Theoretical background for the PHH and the FEH}

It is clear that the effects of trade liberalization on environmental quality depend on, among other factors, jointly by differences in pollution policy and differences in factor endowments, which leads to two competing theories in question.

The PHH predicts that differences in stringency of pollution regulation are the main factor of comparative advantage of countries. Thus, with trade, less developed countries, having weaker environmental policy, become dirtier as they will specialize in dirty-goods production. The underlying reasons for developing countries to set lower standards are threefold. Firstly, the costs of monitoring and exerting pollution standards are relatively higher in developing countries. This is caused, for example, by a scarcity of trained personnel, the high costs of implementing new pollution standards, the difficulty of obtaining modern equipment, corruption (all in comparison to developed countries). Second, developed countries with high incomes generate a larger demand for clean water and air. Developing countries with low levels of income are more focused on extra earnings and jobs, rather than health and pollution. Third, growth in developing countries implies a shift from agriculture to manufacturing, resulting in rapid urbanization and large investments in urban infrastructure, which raises the pollution intensity. In developed countries, however, growth implies a shift from manufacturing to services, which leads to a decrease of pollution intensity.

It is important to distinguish between pollution haven effect and pollution haven hypothesis. The first is that differences in environmental regulation affect plant location decisions and trade flows, i.e. ceteris paribus, stricter environmental policy decreases net exports of dirty goods. The PHH, on the other hand, is a stronger version of the pollution 
haven effect, and it predicts that under free trade, relocation of pollution-intensive goods from stringent pollution regulation countries, usually developed countries, to lax regulation, usually developing, countries takes place. In other words, “...the pollutionhaven effect is so strong that it more than offsets other motives for trade in dirty goods" (Copeland and Taylor, 2004, p.35).

The FEH, on the contrary, asserts that it is differences in endowments and technology, not the differences in pollution regulation that determines trade. It states that the capital intensity is highly correlated with pollution intensity of production (see, e.g. Copeland and Taylor, 2003). Therefore, according to the Hecksher-Ohlin theory of international trade, under the FEH, the capital abundant country exports the capitalintensive (dirty) goods, which stimulates its production, thus raising pollution in the capital abundant country. Conversely, pollution falls in the capital-scarce country as a result of contraction of the production of pollution-intensive goods, because there is no comparative advantage in dirty goods production in the developing world.

We now present the above two theories by graphical illustrations. Denote $X, Y$ and $e$ as the dirty good, the clean good and the emission intensity in a country, respectively. Thus the total emission is $E=e X$, which assumes the fact that emissions are generated only in the production process. For the sake of simplicity, assume a fixed emission intensity, which is the same for two trading countries, rich and poor. The price of dirty good in the developing country is lower than that in the rich country, i.e. $P_{p}^{X}<P_{r}^{X}$, where $p$ and $r$ stand for poor and rich, respectively. This is because the rich country taxes pollution more heavily, so that relatively less dirty good is produced leading to higher price of $X$ in autarky in the developed country. Consequently, for a given price of clean good, the autarky price ratio in the less developed country, $p_{p}=P_{p}^{Y} / P_{p}^{X}$, is higher than that in the rich country, $p_{r}=P_{r}^{Y} / P_{r}^{X}$. Figure 1 shows production possibility lines that are flatter for the developed country and steeper for the poor country, and in autarky the rich country produces more clean good, $Y_{r 0}>Y_{p 0}$, and less dirty good. For the sake of simplicity, indifference curves are not drawn in Figure 1, but the reader should imagine appropriate indifference curves being tangent to the tangency points of price ratios and production possibility curves. Note that since we assume that only production generates pollution, in the figure we do not consider 
consumption points, which are taken into account later. Since the dirty good production is higher in the poor country, the autarky pollution level is higher in the poor country as well, $E_{p 0}>E_{r 0}$. With trade, the rich country will import $X$ from developing country, and the less developed country will import $Y$ from developed country. This results in a world price of $p_{w}$, which contracts further the dirty good production in the rich country and expands it further in the poor country. Hence, pollution increases in the less developed country and decreases in the rich country, i.e. $E_{p 1}>E_{p 0}$ and $E_{r 1}<E_{r 0}$. This is essentially the prediction of the $\mathrm{PHH}$ under the assumption that pollution is generated in the production process.

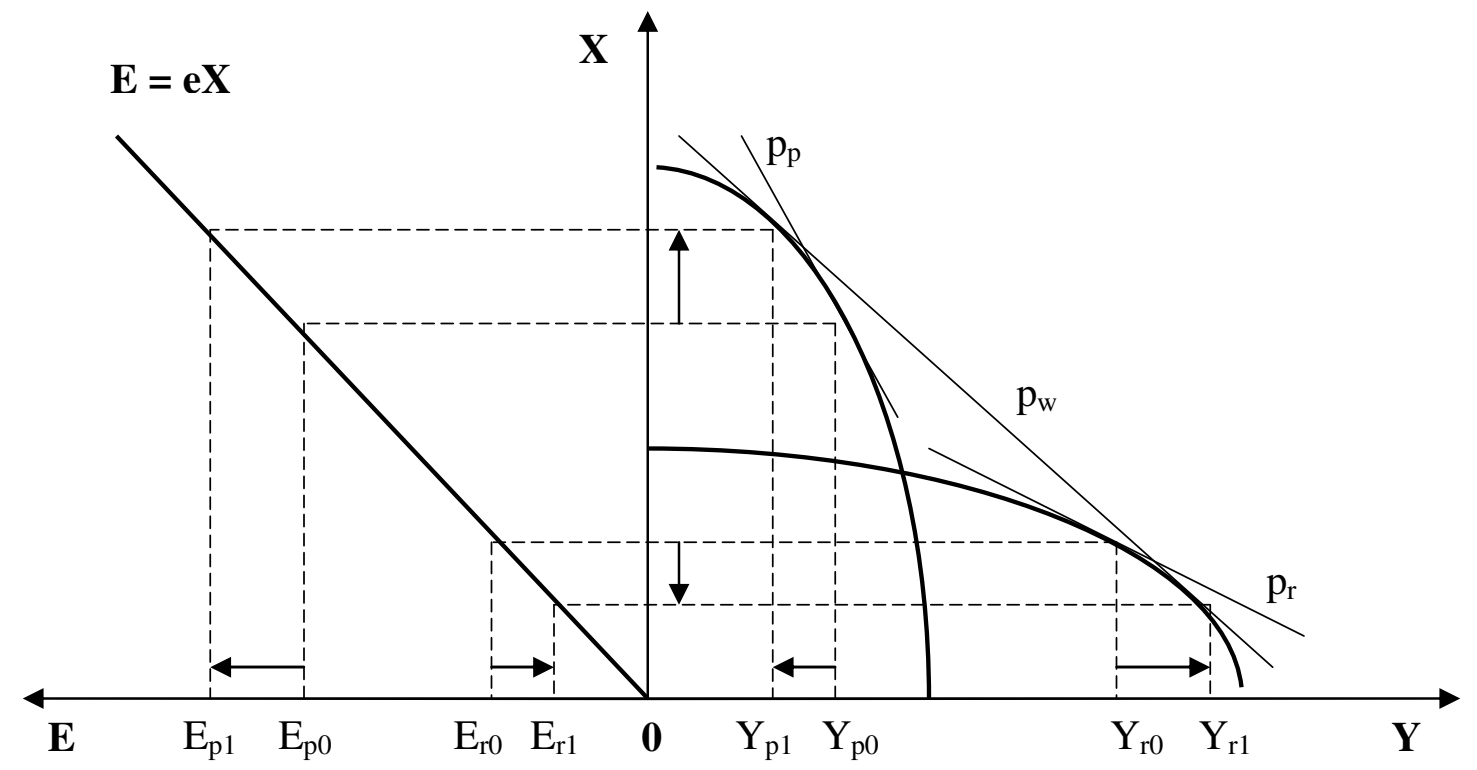

Figure 1. The PHH (and the FEH) under the assumption of production-generated pollution.

Note that Figure 1 is also consistent with the FEH if we consider differences in factor endowments as the main determinant of trade. In this case, $X$ is capital intensive good (see, e.g. Copeland and Taylor, 2003), thus rich country being a capital abundant country will specialize in its production. In Figure 1 we just change letters, namely $r$ for $p$, and vice versa, and the rich (poor) country's production possibility frontier will be the steeper (flatter) one. As a result we see that trade is good in terms of environmental pollution for the developing country, and bad for the developed country. 
Next, consider the case when pollution is generated in the consumption process. Recall that the consumption points were not needed for our analysis in Figure 1, since we were interested only in production-generated pollution. The autarky case is the same as in Figure 1, i.e. production $(X)$ is equal consumption $\left(X_{c}\right)$, and thus we have the same pollution levels in the two countries as in Figure 1. However, with trade the consumption differs from production, thus pollution will be different than in the first case. Figure 2 shows that, under the assumption of similar preferences of the two trading partners, with trade, an equilibrium point of $A$ is achieved. It is important to notice that we assume that the preferences do no depend on emissions; otherwise the equilibrium price with trade does not necessarily ends up on the world price ratio line in this simple graph. It is obvious from the figure that the rich country now consumes less clean good $Y$ and more dirty good $X$, compared to autarky case, which means that pollution increases in the rich country. The complete reversal is true for the poor country. Notice that if we consider only consumption generated pollution under the assumption of pollution stringency being the main determinant of trade, the effect of free trade on the environment is consistent with the FEH, not with the PHH. Consequently, different assumptions about pollution generation and the major factor of trade give predictions that are consistent with either the $\mathrm{PHH}$ or the FEH. This stresses further the importance of empirical tests of the hypotheses in question. In similar way, as we did in the previous case, changing the determinant of trade from environmental stringency policy to factor endowments, gives reverse prediction in Figure 2. But then we have to change price ratios and production possibility frontiers for rich and poor countries as in the previous case.

In Figure 2 we also show the pollution levels under production-generated pollution. Note that this representation will be correct only if the pollution intensities for consumption and production are the same, otherwise the illustration is somewhat complex with two lines of emissions, however the qualitative results will be unchanged. Since in real life part of pollution is generated in the production process and the other part in the consumption process, total pollution emissions would be somewhere in between the two points of these two extreme assumptions about pollution generation. The possible ranges of pollution levels with free trade for the two countries are shown in Figure 2. Consequently, from the figures discussed it seems that theoretically free trade may have 
negative, zero or positive effect on the environment. Which effect prevails is a matter of empirical research.

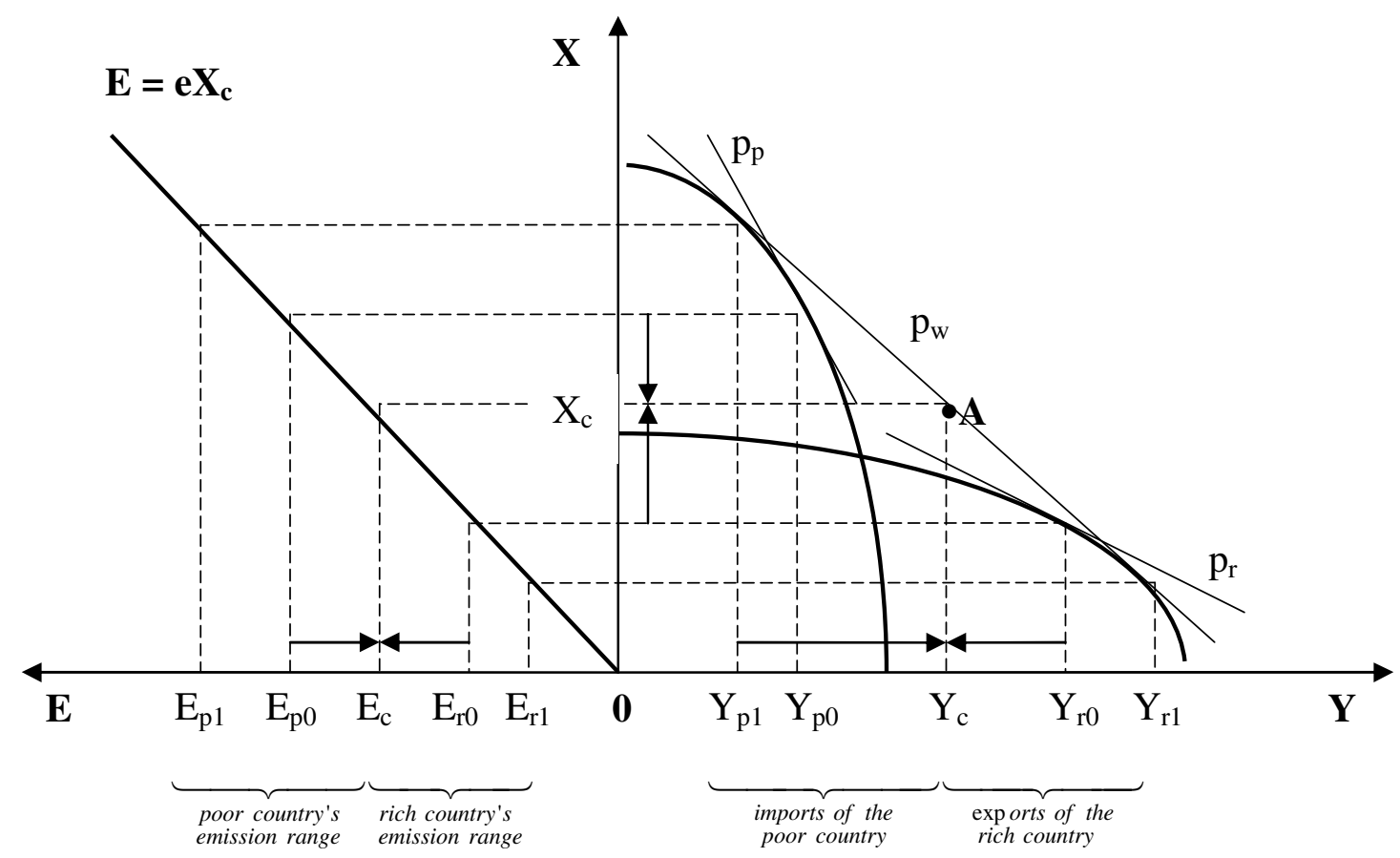

Figure 2. The PHH (and the FEH) under the assumption of consumption-generated pollution.

\section{Methodology}

The methodology used in this paper is based on Leontief's Input-Output framework (see e.g. Leontief, 1966; Miller and Blair, 1985), where the structure of an economy is analyzed in terms of interrelationships between production sectors. The open, static input-output model is characterized as follows.

Let $a_{i j}$ be the unit input coefficient denoting the amount of input $i$ needed to produce a unit of good $j$. Thus, to produce $x_{j}$ units of good $j$, one needs $x_{i j}=a_{i j} x_{j}$ units of input $i$. For each sector $i$ the value of total production $\left(x_{i}\right)$ is the sum of the intermediate demand $\left(x_{i j}\right)$ and final demand $\left(y_{i}\right)$ : 


$$
x_{i}=\sum_{j=1}^{n} x_{i j}+y_{i}, \quad i=1, \ldots, n
$$

where $x_{i j}$ symbolizes the value of domestic intermediate deliveries in currency unit (e.g. in USD) from sector $i$ to sector $j, y_{i}$ is the amount of sales from sector $i$ to final demand categories (consisting of private consumption, government spending, gross capital formation and exports), and $n$ is the number of production sectors. Using the definition of input coefficients, the accounting equation (1) can be rewritten as:

$$
x_{i}=\sum_{j=1}^{n} a_{i j} x_{j}+y_{i}, \quad i=1, \ldots, n
$$

Forming column vectors of total sectoral output and final demand, it is possible to utilize linear matrix algebra to arrive at a reduced form of input-output economy. The output column vector, $\mathbf{x}$, is endogenous and the column final demand vector, $\mathbf{y}$, is exogenous. Given the output vector $\mathbf{x}^{\prime}=\left(x_{1}, x_{2}, \ldots, x_{n}\right)$, the final demand vector $\mathbf{y}^{\prime}=\left(y_{1}\right.$, $\left.y_{2}, \ldots, y_{n}\right)$ and $n \times n$ matrix of input coefficients $\mathbf{A}=\left(a_{i j}\right)$, equation (2) can be expressed in the following matrix form ${ }^{4}$ :

$$
\mathbf{x}=\mathbf{A} \mathbf{x}+\mathbf{y}
$$

This equation is the fundamental equation of the open Leontief system, which states that the gross output, $\mathbf{x}$, is the sum of all intermediate demand, $\mathbf{A x}$, and final demand, $\mathbf{y}$. The solution of input-output model in (3) is given by $\mathbf{x}=(\mathbf{I}-\mathbf{A})^{-\mathbf{1}} \mathbf{y}=\mathbf{L y}$, where $\mathbf{L}=(\mathbf{I}-\mathbf{A})^{-\mathbf{1}}$ is known as the "Leontief inverse" and $\mathbf{I}$ is a $n \times n$ identity matrix. The typical element of Leontief inverse $l_{i j}$ denotes the output of commodity $i$ (in USD) required directly and indirectly per currency unit (one USD) of final demand for commodity $j$.

Under the assumption of fixed input coefficients, the amount of domestic outputs, $\widetilde{\mathbf{x}}$, necessary to satisfy any exogenously specified final demand vector, $\tilde{\mathbf{y}}$, are determined by $\widetilde{\mathbf{x}}=(\mathbf{I}-\mathbf{A})^{-1} \widetilde{\mathbf{y}}$. The production of required outputs, $\widetilde{\mathbf{x}}$, needs inputs of fossil fuels, namely solid (coal), liquid (oil) and gaseous (natural gas), that we have to compute next in our input-output framework. These fossil fuels in our empirical study

\footnotetext{
${ }^{4}$ Adopting usual convention, matrices are given in bold, capital letters; vectors in bold, lower case letters; and scalars in italicized, lower case letters. Vectors are columns by definition, thus row vectors are obtained by transposition, indicated by a prime.
} 
are given by two commodities: crude petroleum and natural gas (sector 5) and coal (sector 6). For the rest of the paper we call them simply oil and coal, respectively. ASSUMPTION 1. Fossil fuels are combusted somewhere in the production process when used as an intermediate input.

Combustion of oil and coal generates carbon, sulphur and nitrogen dioxides, i.e. $\mathrm{CO}_{2}, \quad \mathrm{SO}_{2}$ and $\mathrm{NO}_{\mathrm{x}}$ emissions, respectively. Following Dietzenbacher and Mukhopadhyay (2004), we first denote the rows corresponding to oil and coal sectors of the input coefficients matrix $\mathbf{A}$ by $\mathbf{a}_{5}^{\prime}$ and $\mathbf{a}_{6}^{\prime}$, respectively. The $j$ th element of the row vector $\mathbf{a}_{6}^{\prime}$ is the amount (in millions) in US dollars (USD) of domestically produced coal used as input for one million USD of output of commodity $j$. Production sectors besides domestically produced oil and coal, use imported fossil fuels as well, which we denote by $\mathbf{b}_{5}^{\prime}$ and $\mathbf{b}_{6}^{\prime}$ for imported oil and coal, respectively. Hence, the vector $\mathbf{a}_{6}^{\prime}+\mathbf{b}_{6}^{\prime}$ gives the total amount of coal in USD used as an input per million USD of output in the US. Consequently, the $j$ th element of the vector $\left(\mathbf{a}_{6}^{\prime}+\mathbf{b}_{6}^{\prime}\right) \mathbf{L}$ gives the input in millions USD of coal (both domestically produced and imported) necessary to satisfy one million USD of final demand for commodity $j$. Note that in the same way we compute inputs of fossil fuels for the Chinese economy.

To test empirically the PHH and the FEH we need the above three estimated pollutants emissions (which by assumption 1 are combusted in the production process) that are calculated from fossil fuels in currency units using the guidelines of the Intergovernmental Panel on Climate Change (IPCC). The amounts of oil and coal in currency units are transformed first into million tons of oil equivalent (mtoe), which are then converted into million tons $(\mathrm{mt})$ of emissions.

The conversion factors are estimated as follows. First from the IPCC guidelines we have that:

$$
\left(\begin{array}{l}
\text { Emissions per } \\
\text { mtoe of fuel }
\end{array}\right)=\left(\begin{array}{l}
\text { Fuel's emission } \\
\text { factor }
\end{array}\right) \times\left(\begin{array}{l}
\text { Fraction of } \\
\text { pollution oxidized }
\end{array}\right) \times\left(\begin{array}{l}
\text { Molecular weight } \\
\text { ratio of emission }
\end{array}\right)
$$

For example, in the case of crude petroleum and natural gas (oil), the carbon emission factor equals $0.77 \mathrm{mt}$ of carbon per mtoe of oil, and $99.25 \%$ of the carbon is oxidized. The molecular weight of $\mathrm{CO}_{2}$ is 44.01 and that of $\mathrm{C}$ is 12.011 , thus the molecular weight 
ratio equals 44.01/12.011 $=3.66 \mathrm{mt}$ of $\mathrm{CO}_{2}$ per $\mathrm{mt}$ of $\mathrm{C}$. Consequently, the combustion of one mtoe of oil results in generation of $0.77 \times 0.9925 \times(44.01 / 12.011)=2.800 \mathrm{mt}$ of $\mathrm{CO}_{2}$ emission. Multiplication of this number by mtoe/(million USD) ratio of oil industry gives $\mathrm{mt}$ of $\mathrm{CO}_{2}$ that is generated by the combustion of one million USD of oil. In China, for example, in 1997 oil production was 163139.4528 million Renmibi (RMB), and according to International Energy Agency (IEA) statistics 181.875 mtoe of oil was produced . Thus mtoe/(million RMB) ratio is 0.0011. Consequently, the combustion of one million RMB of oil generates $3.1218 \times 10^{-3}(2.800 \times 0.0011) \mathrm{mt}$ of $\mathrm{CO}_{2}$. The obtained conversion factor we denote by $c_{5}$, where 5 stands for combustion of oil. Accordingly, subscript 6 indicates combustion of coal, and we denote conversion factors generation of $\mathrm{SO}_{2}$ and $\mathrm{NO}_{\mathrm{x}}$ emissions (in $\mathrm{mt}$ ) by $s$ and $n$, respectively.

Table 1. Conversion factors

\begin{tabular}{|c|c|c|c|c|c|c|}
\hline & \multicolumn{6}{|c|}{ Emissions in million tons } \\
\hline & $\begin{array}{c}c_{r, U S} \\
\left(\mathbf{C O}_{\mathbf{2}}\right)\end{array}$ & $\begin{array}{c}S_{r, U S} \\
\left(\mathbf{S O}_{\mathbf{2}}\right)\end{array}$ & $\begin{array}{c}n_{r, U S} \\
\left(\mathbf{N O}_{\mathbf{x}}\right)\end{array}$ & $\begin{array}{l}c_{r, C H} \\
\left(\mathbf{C O}_{2}\right) \\
\end{array}$ & $\begin{array}{c}s_{r, C H} \\
\left(\mathbf{S O}_{\mathbf{2}}\right)\end{array}$ & $\begin{array}{l}n_{r, C H} \\
\left(\mathbf{N O}_{\mathbf{x}}\right)\end{array}$ \\
\hline \multicolumn{7}{|l|}{ Year 1992} \\
\hline $\begin{array}{l}\text { Combustion of one million USD / } \\
\text { RMB of: }\end{array}$ & & $\times 10^{-3}$ & & & $\times 10^{-3}$ & \\
\hline crude oil \& natural gas $(r=5)$ & 22.4236 & 0.2382 & 0.0261 & 7.2493 & 0.0770 & 0.0084 \\
\hline $\operatorname{coal}(r=6$ & 38.0158 & 0.1131 & 1.1152 & 14.8868 & 0.0443 & 0.4367 \\
\hline \multicolumn{7}{|l|}{ Year 1997} \\
\hline $\begin{array}{l}\text { Combustion of one million USD / } \\
\text { RMB of: }\end{array}$ & & $\times 10^{-3}$ & & & $\times 10^{-3}$ & \\
\hline crude oil \& natural gas $(r=5)$ & 25.7160 & 0.2732 & 0.0299 & 3.1218 & 0.0332 & 0.0036 \\
\hline $\operatorname{coal}(r=6)$ & 47.5345 & 0.1414 & 1.3945 & 6.0860 & 0.0181 & 0.1785 \\
\hline
\end{tabular}

For carbon dioxide we have used the emission factor of coal being 0.55 ( $\mathrm{mt}$ of $\left.\mathrm{CO}_{2}\right) /$ mtoe. The sulphur emission factors of $0.003\left(\mathrm{mt}\right.$ of $\left.\mathrm{SO}_{2}\right) / \mathrm{mtoe}$ for coal, and 0.015 $\left(\mathrm{mt}\right.$ of $\left.\mathrm{SO}_{2}\right) /$ mtoe for oil have been used. Nitrogen emission factors are 0.018 ( $\mathrm{mt}$ of $\left.\mathrm{NO}_{\mathrm{x}}\right)$ /mtoe for coal and $0.001\left(\mathrm{mt}\right.$ of $\left.\mathrm{NO}_{\mathrm{x}}\right) /$ mtoe for oil. Finally, the molecular weight ratios of carbon, sulphur and nitrogen emissions are 3.66, 2 and 3.28, respectively. Table 1 presents the estimated conversion factors. Note that while the US conversion factors are 
close to each other in size, those of China differ largely between 1992 and 1997. This is caused primarily because of large emissions and rather small outputs of oil and coal in 1992, which resulted in high mtoe/(million RMB) ratios of the two fossil fuels.

Using conversion factors, now the $j$ th element of the vector $c_{5}\left(\mathbf{a}_{5}^{\prime}+\mathbf{b}_{5}^{\prime}\right) \mathbf{L}$ indicates carbon emission (in $\mathrm{mt}$ ) that is required for the production of one million USD of final demand of commodity $j$, as a result of the combustion of coal. The total $\mathrm{CO}_{2}$ emission per one million USD of final demand, due to the combustion of both oil and coal, is thus equal to the elements of the vector $\left[c_{5}\left(\mathbf{a}_{5}^{\prime}+\mathbf{b}_{5}^{\prime}\right)+c_{6}\left(\mathbf{a}_{6}^{\prime}+\mathbf{b}_{6}^{\prime}\right)\right] \mathbf{L}$. Similarly, for any exogenous vector of final demand $\widetilde{\mathbf{y}}$, the total emission of $\mathrm{CO}_{2}$ is obtained as a scalar from $\left[c_{5}\left(\mathbf{a}_{5}^{\prime}+\mathbf{b}_{5}^{\prime}\right)+c_{6}\left(\mathbf{a}_{6}^{\prime}+\mathbf{b}_{6}^{\prime}\right)\right] \mathbf{L} \tilde{\mathbf{y}}$. By the same token, the sectoral total emissions of $\mathrm{CO}_{2}$ are given by the row vector $\left[c_{5}\left(\mathbf{a}_{5}^{\prime}+\mathbf{b}_{5}^{\prime}\right)+c_{6}\left(\mathbf{a}_{6}^{\prime}+\mathbf{b}_{6}^{\prime}\right)\right] \mathbf{L} \hat{\tilde{\mathbf{y}}} .^{5}$ The $j$ th element of this vector gives the emissions that are directly and indirectly required to satisfy the final demand for commodity $j, \tilde{y}_{j}$. In general for any exogenously specified final demand in country, $\tilde{\mathbf{y}}$, the total carbon, sulphur and nitrogen emissions (in $\mathrm{mt}$ ), due to the combustion of oil and coal, are given by:

$$
\left(\begin{array}{l}
\mathbf{c}^{\prime} \\
\mathbf{s}^{\prime} \\
\mathbf{n}^{\prime}
\end{array}\right)=\left(\begin{array}{ll}
c_{5} & c_{6} \\
s_{5} & s_{6} \\
n_{5} & n_{6}
\end{array}\right)\left(\begin{array}{l}
\left(\mathbf{a}_{5}^{\prime}+\mathbf{b}_{5}^{\prime}\right) \\
\left(\mathbf{a}_{6}^{\prime}+\mathbf{b}_{6}^{\prime}\right)
\end{array}\right) \mathbf{L} \hat{\tilde{\mathbf{y}}} \equiv\left(\begin{array}{l}
\mathbf{d}^{\prime} \\
\mathbf{f}^{\prime} \\
\mathbf{g}^{\prime}
\end{array}\right) \mathbf{L} \hat{\tilde{\mathbf{y}}},
$$

where $\mathbf{c}^{\prime}, \mathbf{s}^{\prime}$ and $\mathbf{n}^{\prime}$ denote the row vectors of total emissions of $\mathrm{CO}_{2}, \mathrm{SO}_{2}$ and $\mathrm{NO}_{\mathrm{x}}$ at the sectoral level, respectively, and we simplify the expressions, e.g. $c_{5}\left(\mathbf{a}_{5}^{\prime}+\mathbf{b}_{5}^{\prime}\right)+c_{6}\left(\mathbf{a}_{6}^{\prime}+\mathbf{b}_{6}^{\prime}\right)=\mathbf{d}^{\prime}$.

\section{Testing the PHH and the FEH}

For the sake of simplicity, assume that the world is made up of two regions (or countries), which we call the North and the South. By the usual convention in the literature on international trade, North represents the rich, developed region and South is a poorer,

\footnotetext{
${ }^{5} \hat{\mathbf{y}}$ denotes the $n \times n$ diagonal matrix with the elements of the vector $\tilde{\mathbf{y}}$ on its main diagonal.
} 
developing region. In the empirical application we distinguish three cases: (i) we use the US for North and the rest of the world (ROW) as South; (ii) China represents South and the ROW North; (iii) bilateral trade only, when the US is used as North and China is South.

In our empirical study of the PHH, we imagine a situation in which the US (China), simultaneously increase both its exports and imports by the same amount of money, say one million USD (RMB), so that the current account balance remains unchanged. The central issue then is how this increase in trade would effect the generation of $\mathrm{CO}_{2}, \mathrm{SO}_{2}$ and $\mathrm{NO}_{\mathrm{x}}$ emissions. Following Dietzenbacher and Mukhopadhyay (2004), we denote the changes in the exports and imports by the vectors $\Delta \mathbf{e}$ and $\Delta \mathbf{m}$, respectively, and use indexes of $N$ and $S$ for North and South, respectively. Thus we always have that $\Delta \mathbf{e}_{N}=\Delta \mathbf{m}_{S}$, i.e. the changes in the exports of North is equal to the changes in the imports of South. Note that this is true for case (iii) in an empirical application as well, since we consider bilateral trade setting only. Likewise, we have $\Delta \mathbf{e}_{S}=\Delta \mathbf{m}_{N}$. By our assumption, the total value of changes in exports and imports is the same, i.e. $\sum_{i}\left(\Delta \mathbf{e}_{k}\right)_{i}=\sum_{i}\left(\Delta \mathbf{m}_{k}\right)_{i}$ for $k=N, S$.

From equation (4) we know that the extra one million USD worth of final demands for all commodities, end up with the emissions of $\mathrm{CO}_{2}$ (in mt) equal to the elements of the vector $\mathbf{d}^{\prime} \mathbf{L}$ that are required to satisfy those demands, due to the combustion of oil and coal. So let denote this by $\mathbf{d}_{N}^{\prime} \mathbf{L}_{N}$ for North and $\mathbf{d}_{S}^{\prime} \mathbf{L}_{S}$ for South. When the exports of North (South) are increased, those commodities are produced at home, which yields more $\mathrm{CO}_{2}$ emissions amounted to $\mathbf{d}_{N}^{\prime} \mathbf{L}_{N}\left[\Delta \mathbf{e}_{N}\right]\left(\mathbf{d}_{S}^{\prime} \mathbf{L}_{S}\left[\Delta \mathbf{e}_{S}\right]\right)$. Accordingly, the increase in imports of North (South) results in less carbon emissions to the amount of $\mathbf{d}_{N}^{\prime} \mathbf{L}_{N}\left[\Delta \mathbf{m}_{N}\right]\left(\mathbf{d}_{S}^{\prime} \mathbf{L}_{S}\left[\Delta \mathbf{m}_{S}\right]\right)$, since these products are no longer produced at home. Let the scalar $\Delta \pi_{N}^{c}\left(\Delta \pi_{S}^{c}\right)$ be the extra $\mathrm{CO}_{2}$ emissions in North (South) induced by increased trade, hence we have $\Delta \pi_{N}^{c}=\mathbf{d}_{N}^{\prime} \mathbf{L}_{N}\left[\Delta \mathbf{e}_{N}-\Delta \mathbf{m}_{N}\right]$ ( $\left.\Delta \pi_{S}^{c}=\mathbf{d}_{S}^{\prime} \mathbf{L}_{S}\left[\Delta \mathbf{e}_{S}-\Delta \mathbf{m}_{S}\right]\right)$. In general, the benefits (losses) in terms of pollution due to increased trade can be written as: 


$$
\left(\begin{array}{c}
\Delta \pi_{k}^{c} \\
\Delta \pi_{k}^{s} \\
\Delta \pi_{k}^{n}
\end{array}\right)=\left(\begin{array}{l}
\mathbf{d}_{k}^{\prime} \\
\mathbf{f}_{k}^{\prime} \\
\mathbf{g}_{k}^{\prime}
\end{array}\right) \mathbf{L}_{k}\left[\Delta \mathbf{e}_{k}-\Delta \mathbf{m}_{k}\right], \quad \text { for } k=N, S
$$

where $\Delta \pi_{k}^{s}$ and $\Delta \pi_{k}^{n}$ stand for the extra emissions of $\mathrm{SO}_{2}$ and $\mathrm{NO}_{\mathrm{x}}$, respectively, caused by increased trade in the region $k$.

The PHH states that an increase in trade would allow rich region (country) North to clean up its environment at the expense of environmental quality in the poorer region of the South. In terms of our model, the PHH will predict $\Delta \pi_{N}^{j}<0$ and $\Delta \pi_{S}^{j}>0$ for $j=$ $c, s, n$. Thus in terms of all three emissions North gains, while South becomes a pollution haven. Because the exports of one region are the imports of the other, the conditions for the $\mathrm{PHH}$ to hold may be rewritten as ${ }^{6}$ :

$$
\left(\begin{array}{l}
\Delta \pi_{N}^{c} \\
\Delta \pi_{N}^{s} \\
\Delta \pi_{N}^{n}
\end{array}\right)=\left(\begin{array}{l}
\mathbf{d}_{N}^{\prime} \\
\mathbf{f}_{N}^{\prime} \\
\mathbf{g}_{N}^{\prime}
\end{array}\right) \mathbf{L}_{N}\left[\Delta \mathbf{e}_{N}-\Delta \mathbf{m}_{N}\right]<\mathbf{0} \text {, and }\left(\begin{array}{c}
\Delta \pi_{S}^{c} \\
\Delta \pi_{S}^{s} \\
\Delta \pi_{S}^{n}
\end{array}\right)=-\left(\begin{array}{l}
\mathbf{d}_{S}^{\prime} \\
\mathbf{f}_{S}^{\prime} \\
\mathbf{g}_{S}^{\prime}
\end{array}\right) \mathbf{L}_{S}\left[\Delta \mathbf{e}_{N}-\Delta \mathbf{m}_{N}\right]>\mathbf{0},
$$

where $\mathbf{0}$ is a 3-dimensional vector of zeros. At the global level, increased trade is beneficial in terms of pollution if the total amount of extra emissions decreases, i.e.

$$
\left(\begin{array}{c}
\Delta \pi_{N}^{c}+\Delta \pi_{S}^{c} \\
\Delta \pi_{N}^{s}+\Delta \pi_{S}^{s} \\
\Delta \pi_{N}^{n}+\Delta \pi_{S}^{n}
\end{array}\right)=\left[\left(\begin{array}{l}
\mathbf{d}_{N}^{\prime} \\
\mathbf{f}_{N}^{\prime} \\
\mathbf{g}_{N}^{\prime}
\end{array}\right) \mathbf{L}_{N}-r\left(\begin{array}{l}
\mathbf{d}_{S}^{\prime} \\
\mathbf{f}_{S}^{\prime} \\
\mathbf{g}_{S}^{\prime}
\end{array}\right) \mathbf{L}_{S}\right]\left[\Delta \mathbf{e}_{N}-\Delta \mathbf{m}_{N}\right]<\mathbf{0},
$$

where $r$ denote the average yearly exchange rate of South currency (in this case, RMB) per national currency of North (USD).

Notice that if the corresponding conversion factors of North and South expressed in the same unit measument, and the technologies of the two regions were the same, then $\mathbf{d}_{N}^{\prime}=r \mathbf{d}_{S}^{\prime}, \mathbf{f}_{N}^{\prime}=r \mathbf{f}_{S}^{\prime}, \mathbf{g}_{N}^{\prime}=r \mathbf{g}_{S}^{\prime}$ and $\mathbf{L}_{N}=\mathbf{L}_{S}$. From equation (7) it is now clear that in this case the change in the world level of pollution is zero, which implies that the gain in terms of extra emissions of one region are the losses of the other. This result is not surprising, since at the world level it does not matter where the production due to increased trade takes place, and losses of one side are exactly offset by gains of the other.

\footnotetext{
${ }^{6}$ The definitions of changes in exports and imports are presented in Section 7.
} 
In the rest of the paper we refer to gains (losses) as gains (losses) in terms of environmental quality when extra emissions decrease (increase).

As a matter of fact, technologies and conversion factors are different, thus we will have four possible outcomes for any $j=c, s, n$ (i.e. $j=\mathrm{CO}_{2}, \mathrm{SO}_{2}$ and $\mathrm{NO}_{\mathrm{x}}$ emissions). First, $\Delta \pi_{N}^{j}<0$ and $\Delta \pi_{S}^{j}<0$, meaning that both regions gains from extra trade. This case is in line with the Ricardian theory, when a country's specialization occurs according to the comparative advantage principle. Second, $\Delta \pi_{N}^{j}>0$ and $\Delta \pi_{S}^{j}>0$. Both regions lose from increased trade, they export goods, the production of which is polluting at home, however, it is relatively clean abroad. This case is theoretically unlikely to occur, because both countries have an incentive to switch their production to other commodities and gain by a complete trade reversal. Third, $\Delta \pi_{N}^{j}>0$ and $\Delta \pi_{S}^{j}<0$. This is the case when North is worse off from extra trade, whereas South is better off, which corresponds to the prediction of the FEH under the strict assumption that North is relatively capital abundant (which is not trivial, see e.g. Leontief paradox). And lastly, the forth case is consistent with what the PHH states, that is $\Delta \pi_{N}^{j}<0$ and $\Delta \pi_{S}^{j}>0$. South becomes the pollution haven from increased trade, while North gains. At the world level, the effect of increased trade is beneficial (harmful) if the expression in equation (7) is negative (positive).

The empirical examination of the FEH is quite similar to that of the $\mathrm{PHH}$, but now we need the direct capital requirements (per million USD or RMB of output) coefficients that are denoted by $\mathbf{k}_{k}^{\prime}$ for the region $k$. Then the vector $\mathbf{k}_{k}^{\prime} \mathbf{L}_{k}$ indicates the total (direct and indirect) capital requirements per unit (in value terms) of final demands in region $k$. Obviously, the total capital requirements of North due to increased trade for the satisfaction of extra exports and imports are $\mathbf{k}_{N}^{\prime} \mathbf{L}_{N}\left[\Delta \mathbf{e}_{N}\right]$ and $\mathbf{k}_{S}^{\prime} \mathbf{L}_{S}\left[\Delta \mathbf{m}_{N}\right]$, respectively. Note that in examining the FEH the foreign capital content of North imports should be estimated on the basis of South input matrix (see later for explanation). However, we did not need to do this for testing the PHH since we were interested in emissions content of domestically produced goods, thus the foreign emissions content of imports is not involved in the analysis of the PHH examination. The FEH states that pollution intensities of production and capital intensities are highly correlated (see e.g. Copeland 
and Taylor, 2003). In our model this prediction for North, for instance, is equivalent to the high positive correlation between $\mathrm{CO}_{2}, \mathrm{SO}_{2}, \mathrm{NO}_{\mathrm{x}}$ emissions intensities, $\mathbf{d}_{N}^{\prime} \mathbf{L}_{N}$, $\mathbf{f}_{N}^{\prime} \mathbf{L}_{N}, \mathbf{g}_{N}^{\prime} \mathbf{L}_{N}$, and capital intensities, $\mathbf{k}_{N}^{\prime} \mathbf{L}_{N}$ and $\mathbf{k}_{S}^{\prime} \mathbf{L}_{S}$. Or alternatively, the FEH is true when the following inequalities hold:

$$
\mathbf{k}_{N}^{\prime} \mathbf{L}_{N}\left[\Delta \mathbf{e}_{N}\right]-\mathbf{k}_{S}^{\prime} \mathbf{L}_{S}\left[\Delta \mathbf{m}_{N}\right]>0 \text {, and } \mathbf{k}_{S}^{\prime} \mathbf{L}_{S}\left[\Delta \mathbf{e}_{S}\right]-\mathbf{k}_{N}^{\prime} \mathbf{L}_{N}\left[\Delta \mathbf{m}_{S}\right]<0 \text {. }
$$

The first part of condition (8) says that in North the total capital required for the production of the set of exports is greater than that for the production of the set of imports, which is exactly what the Heckscher-Ohlin (HO) theory states. That is, North being a rich, capital-abundant and labor-scarce region (country) will export relatively capital intensive goods and will import relatively labor intensive goods with trade. The complete reverse prediction is made for the poorer, labor-abundant and capital-scarce South that is reflected in the second inequality of condition (8). We do not consider the labor requirements for exports and imports in this paper, which is the second part of the HO theory. Note that the foreign (southern) capital content of North's imports is calculated on the basis of the technology of South (i.e. using input matrix of South). And the same is true for the South's imports capital content. The underlying reason is that, although the HO theory assumes identical technologies, it is more reasonable to take into account technological differences of the trading partners. This is justifiable since in the real world the factor price equalization does not hold, which is the basic assumption of the HO theory (see, e.g. Trefler, 1993, 1995; Harrigan, 1997; Duchin, 2004). However, in our empirical analysis because of the lack of capital data for China we examine the FEH only for the US, and instead of capital coefficients of China we use those of the US.

\section{Data sources and data preparation}

To continue with the approach given in previous sections we need input-output (IO) tables, bilateral trade data between the US and China, pollution emissions data of the two countries in question, and direct capital requirements data. We choose 1992 and 1997 as the years of analysis mainly because for the US we have benchmark tables available for these years. 
Input-Output Tables. The US IO tables were obtained from the Bureau of Economic Analysis (BEA), US Department of Commerce. The 1992 IO tables (two-digit data) consisted of 97 industries, and the 1997 summary tables included 134 industries. Values in both tables are expressed in millions of USD at current producers' prices. The corresponding China's IO data were adopted from the Department of National Economic Accounting, National Bureau of Statistics (1996 and 1999, respectively). They are available at the 118 and 124 industry level, respectively, at current producers' prices, RMB ten thousands. To make the tables comparable they have been aggregated to 45 and 46 sectors for 1992 and 1997, respectively, on the basis of the nature of commodities and pollution intensity. Data for US Food Manufacturing and Beverage Manufacturing are available separately for 1997 , but as one sector for 1992, thus we have one sector less for 1992 aggregated tables (see Table A1 and Table A2 for the commodity classifications).

For the present analysis, however, further adjustments were made to the IO tables of both countries. In all available tables, intermediate inputs include the sum of imported and domestically produced goods, but as was mentioned in Section 4 we need domestic value of intermediate goods, on the basis of which corresponding input coefficient matrices and Leontief inverses will be calculated. The fallacy of using this type of IO tables is thoroughly analyzed in Dietzenbacher et al. (2005), which shows that, in particular, multipliers based on these tables are interpreted only under the highly unrealistic assumption of zero imports (changes) leading to biased results. To avoid these problems we have used the technique known as "domestication" in the IO literature. The idea is that domestic deliveries are estimated on the basis of the same share of domestic intermediate use, consumption and investment to each industry (see e.g. Lahr, 2001).

Trade data. Bilateral trade data between the US and China for 1992 and 1997 are available from the national trade data of the Office of Trade and Industry Information (OTII), Manufacturing and Services, International Trade Administration, US Department of Commerce. The data is expressed in current prices, and released according to North American Industry Classification System (NAICS) that made the comparability of IO data and trade data easy. To have exact industrial trade data, the following three items were excluded: Goods returned to Canada, US goods returned and reimported items (NAICS 9800); Special classification provisions (NAICS 9900); and Traded items 
(NAICS ZZZ). Further since exports and imports in IO tables are adjusted for transportation costs, trade margins, vessel and air charges, and custom duty, their direct use would not be indicative of comparative advantage. Therefore the US trade data with the world is taken from the OTII (with the same adjustments) as well. ${ }^{7}$ Finally China's trade data with the world was taken from corresponding IO tables.

Pollution emissions data. The data for carbon, sulphur and nitrogen dioxides from fossil fuel combustion are estimated according to the guidelines of the Intergovernmental Panel on Climate Change (IPCC). Data on two energy sectors (oil and coal) in millions tons of oil equivalent considered in this paper are available from the International Energy Agency (IEA) publications of Energy Balances of OECD countries, 1997-1998 and Energy Balances of Non-OECD countries, 1997-1998. The methodology of estimating corresponding conversion factors is explained in detail in Section 4.

Direct capital input data. The US fixed assets data for 1992 and 1997 were obtained from the BEA estimates of the Current-Cost Net Stock of Private Fixed Assets by Industry (billions of USD, yearend estimates). They include data on equipment such as computers, software, communications, medical equipment, metalworking machinery, autos, engines, aircrafts, ships and boats, railroad equipment, furniture, construction machinery, etc. and structures such as structures of offices, commercial, manufacturing, mining, petroleum and natural gas structures, railroads, farms, etc. That is we used data of nonresidential fixed assets as a proxy of capital, and the first were divided by the industry output to obtain direct capital coefficients. For China we were not able to get capital requirements data so that only a one-sided test of the FEH could be performed.

\section{Empirical examination of the PHH and the FEH}

Test of the PHH. To test empirically the $\mathrm{PHH}$, we start with the assumption of how an extra one billion USD (RMB) increase in exports and imports of the US (China) will effect the generation of pollutant emissions. In particular, this increase in exports

\footnotetext{
${ }^{7}$ We should note that the results of the empirical findings did not change when we used data from the US IO tables as data for trade of the US with the ROW.
} 
(imports) is accompanied by the constant compositional change of industrial exports (imports), i.e. by an equal proportional increase in each export (import) commodity. The results for the US and China for 1997 are given in Table 2 and Table 3, respectively.

The calculations were made without changing the current account balance, which is important since the position of the US and China in their bilateral trade and in the trade with the ROW is kept invariant. ${ }^{8}$ Denoting the US actual exports (in millions USD) to the ROW and to China in 1997 by vectors $\mathbf{e}_{U S / R O W}^{1997}$ and $\mathbf{e}_{U S / C H}^{1997}$, respectively, the sectoral extra exports (in millions USD) due to one billion USD increase in the US exports to both ROW and China are given by the elements of $\Delta \mathbf{e}_{U S / R O W}=(1,000 / 663,197) \mathbf{e}_{U S / R O W}^{1997}$ and $\Delta \mathbf{e}_{U S / C H}=(1000 / 12,638) \mathbf{e}_{U S / C H}^{1997}$, where 663,197 and 12,638 are the total amount of US exports (in million USD) to the ROW and China in 1997, respectively. The same procedure is implemented with respect to imports, so the percentage composition of sectoral exports and imports is invariant. Comparing the two tables, note that in the case of bilateral trade, the change in the US exports (US imports) is equal to the change in China's imports (China's exports), as mentioned in Section 5.

The multipliers in (6), (11) and (16) in Tables 2 and 3 are the elements of the row vectors $\mathbf{d}_{k}^{\prime} \mathbf{L}_{k}, \mathbf{f}_{k}^{\prime} \mathbf{L}_{k}$ and $\mathbf{g}_{k}^{\prime} \mathbf{L}_{k}$ for $k=\mathrm{US}$, China, accordingly. They show the extra emission of $\mathrm{CO}_{2}$ (in thousands tons), $\mathrm{SO}_{2}$ and $\mathrm{NO}_{\mathrm{x}}$ (in tons), respectively, that is required to satisfy one million USD (RMB) worth of final demand for all commodities. Multiplication of these multipliers with the extra exports and imports gives the extra pollutant emissions due to one billion USD (RMB) increase in trade (columns (7)-(10), (12)-(15) and (17)-(20)).

Recall that for the PHH to be a valid hypothesis, we should have that the US gains in terms of pollution, while China loses in terms of emissions from extra trade, i.e. the export related pollution is lower (higher) than the import related pollution for the US (China). Consider first the bilateral trade between the US and China. From Table 2 and Table 3 we clearly see that the export related emissions of all three pollutants are larger than the import related emissions for the US, while the complete reverse is true for China.

\footnotetext{
${ }^{8}$ Throughout the paper when we talk about the trade of China with the ROW, we do not exclude the US from the ROW. Similarly, trade of the US with the ROW includes China as a trading partner as well.
} 
In other words, in 1997 an increase in trade made the environment of the US dirtier, since its exports is more pollution intensive than its imports, whereas China become cleaner in terms of environmental pollution, as the Chinese exports are cleaner than the goods that are replaced by its imports. Therefore the prediction of the PHH is rejected in case of USChina trade in 1997.

Considering the case of the world trade of the US and China, the PHH is rejected only from one side. That is both countries gain from trade when we consider their individual trade with all countries of the world. The US now is also in the position of the winner. However, the fact that China is not a pollution haven is sufficient to reject the $\mathrm{PHH}$ in this case as well.

The same calculations were done for 1992 for both countries (see Table A3 and Table A4 in the Appendix) and, for the purpose of simplicity, we computed the ratios of the export pollution to the import pollution. Thus for the PHH to be true this ratio should be larger than one for China (developing country) and smaller than one for the US (developed country). The overall results are given in Table 4.

\section{Table 4. Ratios of export to import pollution for the US and China}

\begin{tabular}{lcccccc}
\hline \multirow{2}{*}{$\begin{array}{l}\text { Export to import pollution } \\
\text { ratios as a result of trade of }\end{array}$} & \multicolumn{7}{c}{1992} \\
& $\mathrm{CO}_{2}$ & $\mathrm{SO}_{2}$ & $\mathrm{NO}_{\mathrm{x}}$ & $\mathrm{CO}_{2}$ & $\mathrm{SO}_{2}$ & $\mathrm{NO}_{\mathrm{x}}$ \\
\cline { 2 - 7 } the US & 0.65 & 0.59 & 1.12 & 0.72 & 0.68 & 0.98 \\
China & 0.81 & 0.80 & 0.83 & 0.73 & 0.68 & 0.79 \\
& \multicolumn{7}{c}{ with the ROW } \\
\cline { 2 - 7 } the US & 2.04 & 2.22 & 1.37 & 1.84 & 2.01 & 1.23 \\
& 0.61 & 0.55 & 0.68 & 0.68 & 0.64 & 0.72 \\
\hline
\end{tabular}

Note: Ratios for the US and China in the bilateral trade case are not reciprocal of each other.

From this table it is obvious that the PHH is not supported in its empirical test. Special interest of this paper is bilateral trade effect on the environment. All ratios for China are less than one, and those of the US are much greater than one in the bilateral case, indicating that China gained in terms of pollution while the US lost in terms of emissions due to their increased trade. Thus it turns out that the US is the pollution haven rather than China. Notice that ratios of export to import pollution of the US are smaller in 
1997 for all gases than in 1992. On the other hand, China is not characterized as a pollution haven, however, these ratios are increasing over time. Thus there is a convergence of ratios of the US and China.

Considering the environmental effect of trade of the US and China with the ROW, we observe that the situation changes for the US but remains the same for China. China is still not characterized as a pollution haven and moving away from being a pollution haven over time, whereas the US is also gaining from trade in terms of pollution, except for nitrogen dioxide pollution in 1992. At the same time the tendency of gains is decreasing over time for carbon and sulphur dioxides, and increasing for nitrogen emissions. The question arises why the position of the US in terms of environmental gains and/or losses changes when we consider its world trade rather than the US-China bilateral trade only. One possible explanation might be the fact that the main trading partners of the US are developed countries and not developing ones. Looking at the world trade data of the US by countries and taking into account $99 \%$ of its exports and imports for 1992 and 1997, we found that the proportion of the US trade with the developed world is much larger than that with poor countries. Figure 3 below illustrates this point, indicating that US exports to and imports from developed countries amounted to at least 70 percent in 1992, and 64 percent in 1997. On the other hand, the trade with China

Figure 3. The US world trade structure by countries, 1992 and 1997

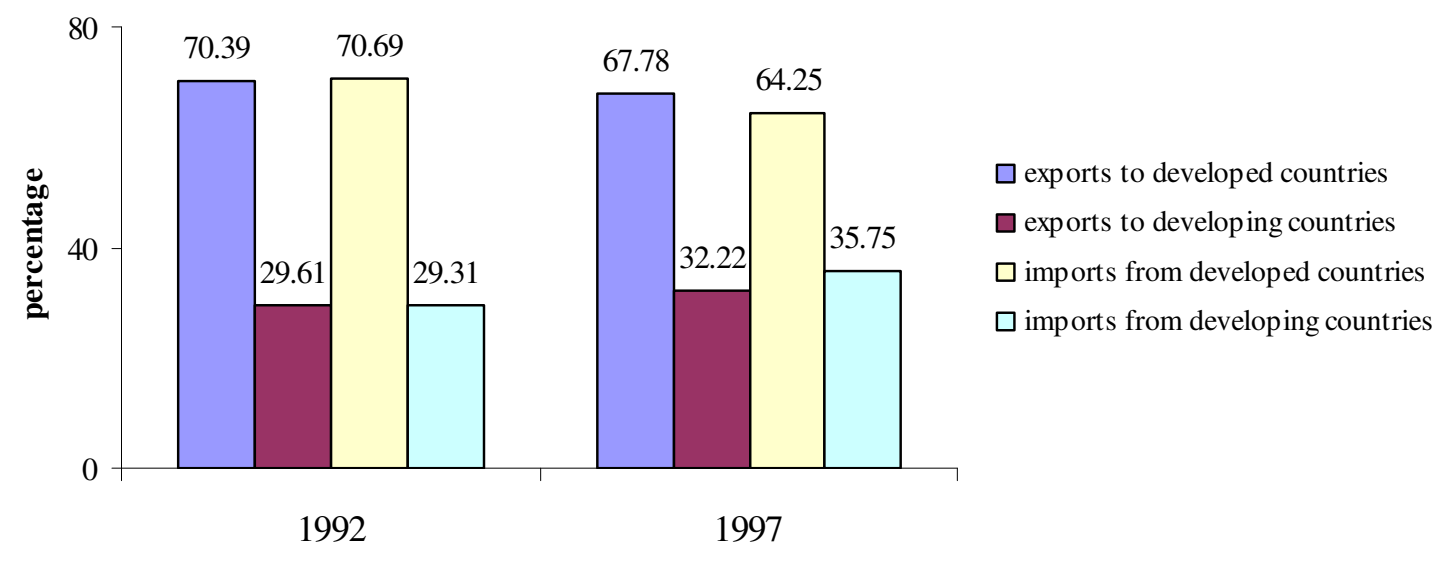

Exports and imports

Source: Office of Trade and Industry Information (OTII), Manufacturing and Services, International Trade Administration, US Department of Commerce. 
comprised only at most 7.25 percent in 1992 and reduced to at least 1.87 percent in 1997 . Thus the data are suggestive of the fact that trade between developed countries is, on average, beneficial for their environment. We are not sure about the pollution effect of trade between the developing countries since the world trade data of China by countries is not available .

Certainly, the volume of pollution calculated by the methodology of this paper depends on both export and import shares, and the size of multipliers. Tables 2 and A2 show that three important export sectors of the US in both 1992 and 1997 (Aircraft and Other Transport Equipment, commodity 33 ${ }^{9}$; Electronic and Communication Equipment, 31; Agricultural and Other Non-electrical Machinery, 30) cover from $47 \%$ to $53 \%$ of all exports depending on its trade with the world or with China only. Similarly, from $45 \%$ to $48 \%$ of all imports are combined in above mentioned commodities 31, 33 and Apparel and Leather Manufacturing, 15. On the other hand, from Tables 3 and 3A we see that the four most important export sectors of China in 1992 and 1997 (Apparel and Leather Manufacturing, 15; Other Manufacturing, 34; Electronic and Communication Equipment, 31; Textiles and Textile Product Mills, 14) include from $45 \%$ to $78 \%$ of all China's exports in its trade with the world and the US, accordingly. Similarly, we observe that from $35 \%$ to $55 \%$ of all China's imports consists of four main import commodities (commodities 30, 31, 33 and 14 all mentioned above).

In the US economy the three largest multipliers are found for Petroleum and Coal Product Manufacturing (commodity 18), Other Utilities (9) and Crude Petroleum and Natural Gas (5) in both 1992 and 1997 in case of $\mathrm{CO}_{2}$ and $\mathrm{SO}_{2}$, except for $\mathrm{CO}_{2}$ multiplier in 1997, where the third largest multiplier has Electricity (8). In the case of $\mathrm{NO}_{\mathrm{x}}$ these are Coal (6), Electricity (8) for both considered years, and the third largest multipliers are found for Petroleum and Coal Product Manufacturing (18) in 1992, and Iron and Steel (25) in 1997. In a similar way, we found that in China the two largest $\mathrm{CO}_{2}$ and $\mathrm{SO}_{2}$ multipliers have Petroleum and Coal Product Manufacturing (18) and Electricity (8) in both considered years, and the third largest multipliers are found for Fertilizers and Pesticide (21) in 1992, and Other Utilities (9) in 1997. The first and third largest multipliers in case of $\mathrm{NO}_{\mathrm{x}}$ are found for Electricity (8), and Fertilizers and Pesticide (21)

\footnotetext{
${ }^{9}$ The number of commodity is consistent with the industry classification given in Table A1.
} 
in both years, and the second largest $\mathrm{NO}_{\mathrm{x}}$ multiplier is observed for Petroleum and Coal Product Manufacturing (18) in 1992 and Other Utilities (9) in 1997.

Closer inspection of these findings suggests giving special attention to Petroleum and Coal Product Manufacturing (18), which has the largest multiplier in the case of $\mathrm{CO}_{2}$ and $\mathrm{SO}_{2}$ for the US and China in both 1992 and 1997. For these two pollutions its multipliers are, on average, 1.95 times larger than the second largest multipliers, and 3.34 times bigger than the third largest multipliers, while having outstanding difference with the rest of all other multipliers. Its trade shares ranking, on average for the US and China both in their trade with the ROW and mutual trade in 1992 and 1997, is 26-th for export shares and 24-th for import shares. On the other hand, commodities with the largest export and/or import shares have very negligible multipliers relative to those of Petroleum and Coal Product Manufacturing (18). Furthermore, Electricity (8) and Other Utilities (9) that generally are found to be in the list of the three largest multipliers in case of all considered pollutants have zero shares in exports and imports in all cases, except for China in its trade with the ROW, where the trade share of Electricity (8) is negligible, being on average 36-th in the ranking of export and import shares. Therefore in our analysis of environmental effect of trade the last two mentioned commodities do not contribute a lot, if at all, to pollution generation caused by trade.

The results found up to now are based of the assumption that fossil fuels (oil and coal) are combusted in the production process, generating pollution. Thus to calculate pollution based on this assumption, we computed how much the exogenous increase in exports and imports generates emissions in the production process in order to satisfy those increases in trade. However, one can notice that this assumption is not a reasonable assumption for Petroleum and Coal Product Manufacturing (18), which we found to have a significant contribution in our computation of pollutions. The point is that for these products combustion takes place in the process of their consumption not production. Thus it is reasonable to estimate pollution generation under the alternative assumption of consumption - generated pollution.

ASSUMPTION 2. Fossil fuels are combusted in the consumption process of oil, coal and petroleum when they are actually consumed as a final product. 
Based on assumption 2, the emissions of $\mathrm{CO}_{2}, \mathrm{SO}_{2}$ and $\mathrm{NO}_{\mathrm{x}}$ are now generated in the consumption process only. We use this assumption for the following three commodities: Crude Petroleum and Natural Gas (5), Coal (6), and Petroleum and Coal Product Manufacturing (18). Recall that based on assumption 1, pollution was generated when an increase in exports takes place and reduced when an increase in imports takes place, and we computed sectoral emissions that were directly and indirectly required to satisfy those increases in exports and imports, due to combustion of oil and coal. Now by assumption 2, any increase in exports and imports of the above three commodities $(5,6$ and 18) does not change the pollution, as it arises only when the last are actually consumed. Exports are consumed abroad, thus pollute the environment of trading partners when products are combusted in the consumption process. In a similar way, an increase of imports leaves the pollution unchanged. That is, import products replace domestically produced goods that are "consumed" at home (consumption includes also use of intermediate inputs). Assuming that imports are not re-exported, pollution due to consumption in the import case is the same as in the no-import case. Combustion of fuels and thus pollution happen at home, no matter whether the goods are imported or produced domestically. Now in generation of emissions only consumption, not production, of the three commodities matters. Thus we can implement the second assumption by setting zero the export and the import related pollution for each of the three commodities in question in Tables 2, 3, 2A and 3A. The results of this estimation are given in Table 5 .

The results clearly are indicative of the fact that under the alternative assumption, the $\mathrm{PHH}$ is rejected as well, since all export pollution to import pollution ratios for China are less than one, and those for the US are greater than one, except for $\mathrm{NO}_{\mathrm{x}}$ in its trade with the ROW in 1997, no matter which trade we consider, bilateral trade only or trade with the ROW. Recall that under the original assumption these ratios were less than one for the US in the case of trade with the ROW.

Let first consider the bilateral trade setting. Under the alternative assumption for China the export related pollution decreases less than import related pollution, resulting in higher ratios of export to import related pollution, which is, on average, 0.72 and is roughly stable over time. On the other hand, for the US the reverse is true, i.e. under the 
assumption of consumption-generated pollution, the export related pollution decreases much more than the import related pollution compared to the original results. As a consequence, the ratios decrease, however they are still much higher than one, and one can also notice their tendency to decline over time as under the original assumption.

Table 5. Emissions and their export to import ratios under the alternative assumption for the US and China

\begin{tabular}{|c|c|c|c|c|c|c|c|c|c|}
\hline \multirow{5}{*}{$\begin{array}{l}\text { Emissions } \\
\text { and their } \\
\text { ratios as a } \\
\text { result of } \\
\text { trade of } \\
\text { the US }\end{array}$} & \multicolumn{9}{|c|}{1992} \\
\hline & \multicolumn{2}{|c|}{$\mathrm{CO}_{2}$} & \multicolumn{2}{|c|}{$\mathrm{SO}_{2}$} & \multicolumn{2}{|c|}{$\mathrm{NO}_{\mathrm{x}}$} & \multirow{2}{*}{$\begin{array}{l}\mathrm{CO}_{2} \\
\text { Ratio }\end{array}$} & \multirow{2}{*}{$\begin{array}{l}\mathrm{SO}_{2} \\
\text { Ratio }\end{array}$} & \multirow{2}{*}{$\begin{array}{l}\mathrm{NO}_{\mathrm{x}} \\
\text { Ratio }\end{array}$} \\
\hline & $\begin{array}{l}\text { Export } \\
\text { pollution }\end{array}$ & $\begin{array}{l}\text { Import } \\
\text { pollution }\end{array}$ & $\begin{array}{l}\text { Export } \\
\text { pollution }\end{array}$ & $\begin{array}{l}\text { Import } \\
\text { pollution }\end{array}$ & $\begin{array}{l}\text { Export } \\
\text { pollution }\end{array}$ & $\begin{array}{l}\text { Import } \\
\text { pollution }\end{array}$ & & & \\
\hline & \multicolumn{9}{|c|}{ with the ROW } \\
\hline & 542.51 & 453.57 & 4599.47 & 3692.05 & 4917.83 & 4676.43 & 1.20 & 1.25 & 1.05 \\
\hline China & \multicolumn{9}{|c|}{ with China } \\
\hline the US & \multicolumn{9}{|c|}{ with the US } \\
\hline China & 382.10 & 529.18 & 2057.66 & 2874.45 & 7816.50 & 10734.21 & 0.72 & 0.72 & 0.73 \\
\hline & \multicolumn{9}{|c|}{1997} \\
\hline & \multicolumn{9}{|c|}{ with the ROW } \\
\hline the US & 483.48 & 414.57 & 4165.43 & 3402.84 & 4137.22 & 4169.64 & 1.17 & 1.22 & 0.99 \\
\hline China & \multicolumn{9}{|c|}{ with China } \\
\hline the US & \multicolumn{9}{|c|}{ with the US } \\
\hline China & 199.44 & 277.64 & 1033.67 & 1475.82 & 4227.58 & 5750.99 & 0.72 & 0.70 & 0.74 \\
\hline
\end{tabular}

Note: $\mathrm{CO}_{2}$ emissions are in thousands tons, $\mathrm{SO}_{2}$ and $\mathrm{NO}_{\mathrm{x}}$ emissions are in tons. The increase in total exports and imports is one billion USD for the US and one billion of RMB for China.

In terms of our graph in Figure 2, the effect of bilateral trade on China's environment can be represented by any point in between points $E_{p 0}$ and $E_{c}$, while the US pollution situation is reflected somewhere in the interval of $E_{c}$ and $E_{r 0}$, under both assumptions of pollution generation. Thus compared to autarky points of $E_{p 0}$ and $E_{r 0}$, China is evidently gaining in terms of pollution from extra trade with the US, whereas the US are losing. This is a complete reverse of the $\mathrm{PHH}$ prediction.

Qualitative results of the world trade setting are very similar to that of the bilateral trade setting. Considering the case of trade of China with the ROW, we find that as in the case of the bilateral trade setting the ratios of export to import related pollution under the alternative assumption are larger than those under the original assumption, except $\mathrm{NO}_{\mathrm{x}}$ in 1992. Notice that the ratio of 0.83 for all gases in both periods does not mean that these 
ratios are exactly equal, and is the result of rounding only. In the case of the US, ratios under the alternative assumption are larger than those under the original assumption (except for $\mathrm{NO}_{\mathrm{x}}$ in 1992), which is the reverse of the bilateral setting results for the US. Note also that all ratios are smaller in the case of bilateral trade than ratios in the case of trade with the ROW for China, and the reverse is true for the US. This means that for China an extra increase in trade with the ROW is less beneficial in terms of emissions than the same increase in bilateral trade with the US. Similarly, the US gets dirtier in its trade with China rather than in its trade with the ROW.

In reality none of the two assumptions concerning pollution generation are true, instead pollution is generated partly because of production and partly due to consumption. To estimate this in our paper we would need the percentage of pollution caused by production and the percentage of pollution due to actual consumption of the three commodities. Then the actual ratios of export to import related pollution would be somewhere in-between the corresponding ratios shown in Table 4 and Table 5. However, it does not matter for our result that the PHH is not supported in the data. Since the USChina trade is of particular interest, then the actual ratios for China (the US) would be smaller (larger) than those under the assumption of consumption-generated pollution given in Table 5, and larger (smaller) than those under the original assumption given in Table 4. Therefore, the US, and not China, is a pollution haven, i.e. the US is a loser while China is a winner in terms of pollution caused by increased trade between them. If we look at ratios in the case of trade of China with the ROW, still our conclusion holds, i.e. China is still gaining. However, the situation changes in case of the US in its trade with the ROW. For $\mathrm{CO}_{2}$ and $\mathrm{SO}_{2}$ emissions we have ratios smaller than one under the original assumption and larger than one under the alternative assumption, thus actual ratios might be either less or greater than one. Thus the effect of increased trade with the ROW on the US environment is not clear in case of $\mathrm{CO}_{2}$ and $\mathrm{SO}_{2}$ emissions. In case of $\mathrm{NO}_{\mathrm{x}}$ emissions, the US actual ratio would be in the interval $(1.05 ; 1.12)$ in 1992 , and it will decrease to a number in the interval of $(0.98 ; 0.99)$. As a result, in terms of $\mathrm{NO}_{\mathrm{x}}$ pollution, the US was losing in 1992 and changed its position to a winner in 1997 in its trade with the ROW. 
Furthermore, comparing the lower and upper bounds (and their changes) of actual ratios, we can conclude that over time in the bilateral trade setting the ratios are decreasing for the US and increasing for China, meaning that losses of the US and benefits of China in terms of pollution have both tendency to decrease over time. ${ }^{10}$ In the setting of trade with the ROW, China's benefits are increasing over time in terms of all emissions. The US actual ratios of export to import related pollution in case of $\mathrm{CO}_{2}$ and $\mathrm{SO}_{2}$ emissions would increase over time if we would give a percentage of larger than $30 \%$ to production-generated pollution. In real life one can expect that the percentage of pollution generated by production is much higher than $30 \%$, thus the US has a tendency of getting dirtier over time in case of the two pollutions in its trade with the ROW.

Finally, let consider the effect of increased trade between the US and China on the environment on the global level. For this purpose we use equation (7) given in Section 5. Obviously we cannot do this in the case of trade of the US and China with the ROW, as the technology of the ROW, which consists of many countries, is missing, and it is impractical to gather and adjust accordingly all the input matrices even if they were available for most developing countries. Therefore we assume that the world consists only of the US and China, and compute how trade effected the global environment on the base of equation (7). The results are given in Table 6.

\section{Table 6. Global pollution in the US-China world}

\begin{tabular}{ccccccc}
\hline \multirow{2}{*}{ Year } & \multicolumn{5}{c}{ Pollution from increased trade under the } \\
\cline { 2 - 7 } & $\mathrm{CO}_{2}$ & $\mathrm{SO}_{2}$ & $\mathrm{NO}_{\mathrm{x}}$ & $\mathrm{CO}_{2}$ & $\mathrm{SO}_{2}$ & $\mathrm{NO}_{\mathrm{x}}$ \\
\cline { 2 - 7 } & -832.75 & -3928.63 & -19080.54 & -544.50 & -1901.69 & -14932.39 \\
1992 & -421.42 & -1176.67 & -12653.75 & -425.03 & -1390.98 & -12009.70 \\
\hline 1997 & -49.39 & -70.05 & -33.68 & -21.94 & -26.86 & -19.57 \\
\hline Change $(\%)$ & Notes: $\mathrm{CO}_{2}$ emissions are in thousands tons, $\mathrm{SO}_{2}$ and $\mathrm{NO}_{\mathrm{x}}$ emissions are in tons. The increase in total exports and \\
imports is one billion USD. We used exchange rates given in the note to Table 1.
\end{tabular}

The major conclusion drawn from Table 6 is that trade at the world level in this two-country setting is beneficial in terms of all emissions. It is clear from the table that

\footnotetext{
${ }^{10}$ We should mention that in the bilateral trade setting the ratio in case of $\mathrm{SO}_{2}$ increases over time in China if we give a percentage of more (or equal to) than $20 \%$ to production generated pollution, which should be the case in reality. Our results on benefits or losses over time are based on the assumption that the percentage of production-generated pollution is fixed for the period of our analysis.
} 
over time these benefits are decreasing for all emissions, and the percentage change in absolute value is higher under the assumption of production-generated pollution. As mentioned above types of pollution found under both assumptions are extreme cases and in real life some percentage of pollution is generated in production and the rest in the consumption processes. Since the signs of pollutions in Table 6 are all negative under both assumptions, then US-China trade is globally beneficial, and the real benefits are somewhere in-between the corresponding emissions under the two assumptions. For any percentage of production-generated pollution, the decrease of real benefits is largest for $\mathrm{SO}_{2}$ emissions and smallest for $\mathrm{NO}_{\mathrm{x}}$ emissions.

Test of the FEH. Our results from the previous analysis are more in line with the FEH and we found that the PHH predictions are not supported in the empirical analysis. However, to be sure that the FEH predictions are valid, we need to test it. As discussed in Section 5, we may go about it in two ways. First, we examine the correlations between pollution intensities and capital intensities of trade that might give some indication on the relationships between the two. Since we do not have capital data for China, the test of the FEH is done only for the US. The simple correlations between pollution multipliers $\left(\mathbf{d}_{U S}^{\prime} \mathbf{L}_{U S}, \mathbf{f}_{U S}^{\prime} \mathbf{L}_{U S}\right.$ and $\left.\mathbf{g}_{U S}^{\prime} \mathbf{L}_{U S}\right)$ and capital multipliers estimated both by domestic and foreign (China's) technologies $\left(\mathbf{k}_{U S}^{\prime} \mathbf{L}_{U S}\right.$ and $\left.\mathbf{k}_{U S}^{\prime} \mathbf{L}_{C H}\right)$ for 1992 and 1997 are given in Table 7.

Table 7. Simple correlation between pollution and capital multipliers for the US

\begin{tabular}{|c|c|c|c|c|}
\hline \multirow[b]{2}{*}{$\begin{array}{l}\text { Pollution } \\
\text { multipliers }\end{array}$} & \multicolumn{2}{|c|}{1992 US capital multipliers based on } & \multicolumn{2}{|c|}{1997 US capital multipliers based on } \\
\hline & $\begin{array}{c}\text { the US Leontief } \\
\text { inverse }\end{array}$ & $\begin{array}{c}\text { China's Leontief } \\
\text { inverse }\end{array}$ & $\begin{array}{c}\text { the US Leontief } \\
\text { inverse }\end{array}$ & $\begin{array}{c}\text { China's Leontief } \\
\text { inverse }\end{array}$ \\
\hline $\mathrm{CO}_{2}$ & $\begin{array}{c}0.4824 * * * \\
(.0008)\end{array}$ & $\begin{array}{c}0.3697 * * \\
(.0124)\end{array}$ & $\begin{array}{l}0.5120 * * * \\
(.0003)\end{array}$ & $0.5382 * * *$ \\
\hline $\mathrm{SO}_{2}$ & $\begin{array}{c}0.4661 * * * \\
(.0013)\end{array}$ & $\begin{array}{c}0.3320 * * \\
(.0259)\end{array}$ & $\begin{array}{l}0.4809 * * * \\
(.0007)\end{array}$ & $\begin{array}{l}0.4995 * * * \\
\quad(.0004)\end{array}$ \\
\hline $\mathrm{NO}_{\mathrm{x}}$ & $\begin{array}{l}0.1978 \\
(.1927)\end{array}$ & $\begin{array}{l}0.2523^{*} \\
(.0945)\end{array}$ & $\begin{array}{c}0.3051 * * \\
(.0392)\end{array}$ & $\begin{array}{c}0.3470 * * \\
(0.0181)\end{array}$ \\
\hline Obs. & 45 & 45 & 46 & 46 \\
\hline
\end{tabular}


Correlation coefficients are indeed all positive, and mostly significant. This confirms the fact stressed in Copeland and Taylor (2003) that the pollution intensities of production are correlated with capital intensities. However, the correlation is not high, and only in two cases we have correlation coefficients more than 0.5 . So one might notice that according to the Heckscher-Ohlin theory the US as a capital-abundant country (assume it is true, recall Leontief paradox questions this assumption), having a comparative advantage in pollution intensive goods, should specialize in pollutionintensive goods production and thus will export them abroad. This conclusion of the FEH is equivalent to the first expression in equation (8), saying that capital content of the US exports is greater than that of its imports. Here recall that because of the lack of data we use $\mathbf{k}_{U S}^{\prime}$ instead of $\mathbf{k}_{C H}^{\prime}$.

The empirical results of US total (direct and indirect) capital requirements in its trade with China are given in Table 8. The major conclusion derived from Table 8 is that the US in its trade with China in 1992 exported less capital-intensive goods than it imported, and in 1997 the US exported more capital-intensive goods relative to capital content of its imports. That is, in 1992 the US needed the total capital requirements of $1,611,245,036$ USD and 1,650,374,613 USD in order to satisfy one billion USD of extra exports and imports, respectively. The same figures for 1997 are 1,651,522,372 and 1,510,707,311, respectively. The ratios of export capital contents to import capital contents are 0.98 and 1.09 for 1992 and 1997, respectively. This means that the FEH prediction fails for 1992, but is true for 1997 for the US in the bilateral trade setting. However, one can notice that the difference between capital contents of exports and imports are small for both years.

Closer inspection of Table 8 reveals that the two most important importing commodities (Apparel and Leather Manufacturing, 15; Other Manufacturing, 34 ${ }^{11}$ ) contribute most to capital contents of the US imports in both years. Furthermore, in 1992 total capital coefficients based on China's technology for these commodities are much higher than those based on US technology. On the other hand, the capital contents of exports of the two commodities are very small compared to their import capital contents.

\footnotetext{
${ }^{11}$ Recall that commodity number is in correspondence with Table A1, thus in Table 8 for 1992 these commodities would be 14 and 33, respectively.
} 
This essentially caused the FEH to fail in 1992 for the US in its trade with China. Note also that four commodities of Other Utilities (9), Real Estate and Resident Services (39), Crude Petroleum and Natural Gas (5), and Coal (6) are the most capital-intensive commodities.

We also calculated the total capital requirements necessary to satisfy one billion USD of extra exports and imports in the US in its trade with the ROW. For estimating the capital contents of imports we used total capital coefficients based on both US and China technologies. The findings are given in Table 9.

Table 9. The US capital requirements in its trade with the rest of the world

\begin{tabular}{|c|c|c|c|c|c|}
\hline \multirow[b]{2}{*}{ Year } & \multicolumn{3}{|c|}{ Total capital requirements to satisfy one millions USD of } & \multirow{2}{*}{$\begin{array}{c}\text { Ratio } \\
(4)= \\
(1) /(2)\end{array}$} & \multirow{2}{*}{$\begin{array}{c}\text { Ratio } \\
(5)= \\
(1) /(3)\end{array}$} \\
\hline & $\begin{array}{c}\text { exports } \\
\text { (1) }\end{array}$ & $\begin{array}{l}\text { imports } \\
\text { (2) }\end{array}$ & $\begin{array}{l}\text { imports } \\
\text { (3) }\end{array}$ & & \\
\hline 1992 & 1484.3623 & 1715.6852 & 1882.2935 & 0.87 & 0.79 \\
\hline 1997 & 1496.0496 & 1826.7729 & 1874.0289 & 0.82 & 0.80 \\
\hline
\end{tabular}

Note: Total capital requirements are in millions USD necessary to satisfy extra one billion USD of exports and imports. Imports in (2) are derived by multiplication of total capital coefficients based on US technology by extra imports. Similarly, in calculation of imports capital contents in (3) we have used total capital requirements based on China's technology matrix.

The main conclusion derived from Table 9 is that in its trade with the ROW the US is importing more capital-intensive goods and exporting less capital-intensive goods. This is certainly not what the FEH states. Note again that the majority trading partners of the US are developed countries (see Figure 3), thus the results in Table 9 are more representative of trade between the developed world, rather than that of trade between developed and developing countries.

All in all our results seems to reject the FEH as well, since the prediction of the FEH is not supported by the data for US-China trade in 1992. Our empirical examination thus questions the FEH itself. We already found that the correlation between capital intensity and pollution intensity of production is rather small, which would raise a reasonable doubt about the existence of the FEH. Or if the theory is correct, then we again encounter the famous Leontief Paradox (for 1992) that questions the credibility of the assumption that the US is a capital-abundant country.

As a last exercise we integrated the results of the test of the $\mathrm{PHH}$ and that of the FEH together. First, we computed real export and import related emissions for different 
percentages of production - (hence consumption -) generated pollution. Then we divide these pollutions by corresponding export and import related total capital requirements expressed in millions USD. We should mention that we have used the total capital contents of US imports in its trade with the ROW that was estimated by own technology, i.e. using the US Leontief inverse. Finally, the ratios of export related pollution per million USD export capital requirements to import related pollution per million USD

\section{Figure 4. The ratios of export related pollution per export capital requirements to import related pollution per import capital requirements}

(a) 1992

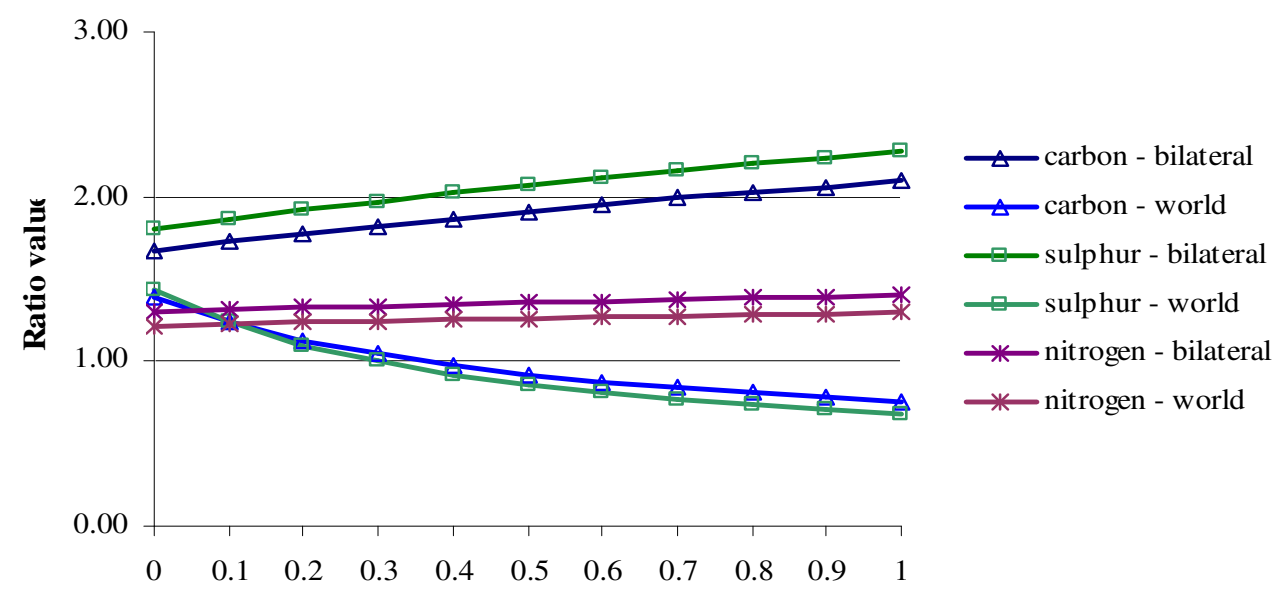

Share of production-generated pollution

(b) 1997

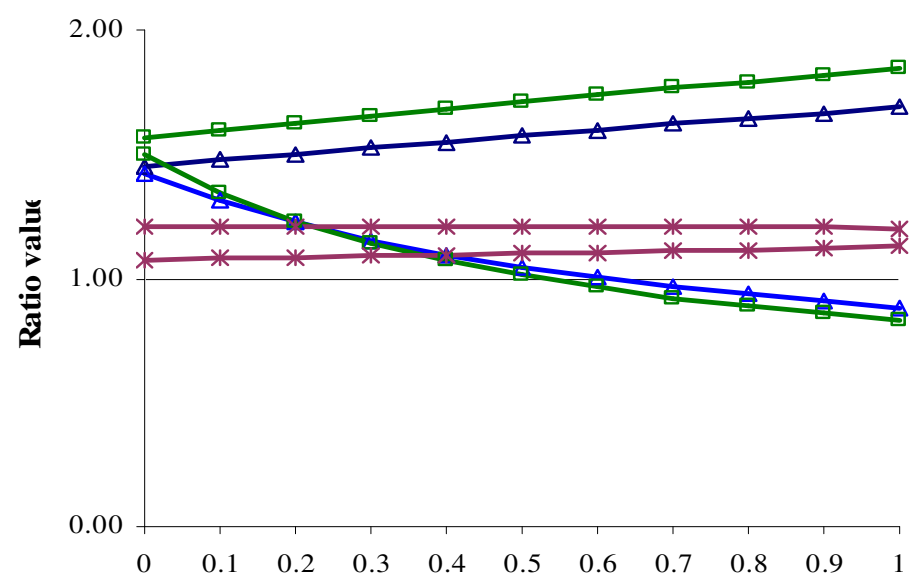

Share of production-generated pollution

Note: Ratios representing trade of the US with the ROW are sloping downwards for all pollutions except for nitrogen, and are represented by lower lines, except for nitrogen pollution in 1997. Capital requirements are in millions USD. 
import capital requirements were obtained. These ratios are given in Figure 4. In the USChina trade setting, these ratios are greater than one for any percentage of production generated pollution. Consequently, export related pollution per million USD capital requirements is higher than import related pollution per million USD capital requirements. Thus taking the capital endowment "effect" into account, it turns out that an extra increase in the trade of the US with China will make the US environment dirtier. The same conclusion is true in trade of the US with the ROW in case of nitrogen. However, for $\mathrm{CO}_{2}$ and $\mathrm{SO}_{2}$ emissions the ratios are less than one for production generated pollution percentage of larger or equal to 30\% and 60\% in 1992 and 1997, respectively. For these values (and higher) the US is benefiting in terms of $\mathrm{CO}_{2}$ and $\mathrm{SO}_{2}$ pollution when we take capital endowment "effect" into account. Over time these ratios in both the bilateral and world trade setting are decreasing, meaning that losses (benefits) are decreasing.

\section{Summary and conclusions}

In this paper we have addressed the problem of the effect of free trade on the environment. In this concern the two competing theories of the pollution haven hypothesis and the factor endowment hypothesis were examined empirically for the US and China. The $\mathrm{PHH}$ predicts that differences in stringency of pollution regulation is the main factor of comparative advantage of countries, thus with trade less developed countries, having weaker environmental policy, become dirtier as they will specialize in dirty-goods production. The FEH, on the contrary, asserts that it is not the differences in pollution policy, but differences in endowments or technology that determine trade, and predicts that the capital abundant country exports the capital-intensive (dirty) goods, which stimulates its production, thus raising pollution in the capital abundant country, and the reverse in true for developing nations.

Using input-output analysis as our main study instrument, we have calculated by how much the pollution of $\mathrm{CO}_{2}, \mathrm{SO}_{2}$ and $\mathrm{NO}_{\mathrm{x}}$ emissions will increase in the US and China if exports and imports of the two countries in question increase by the same 
amount. In the empirical application we distinguish three cases: (i) US trade with the rest of the world (ROW); (ii) China's trade with the ROW; (iii) bilateral US-China trade only. For the PHH to be true the export related pollution of China (the US) (less) should be larger than the import related pollution due to increased trade. The point is that exports make the home environment dirtier, since these products are produced domestically, thus generate pollution. In a similar way, imports decrease pollution as these commodities are no longer produced at home, thus generate pollution in the country of origin. The effects of one million USD (RMB) increase in US (China) trade on emissions were obtained from computing fossil fuels (oil, coal and petroleum) embodied in each commodity under the assumptions of production- and consumption-generated pollution. Then the actual pollutions were computed for different shares of production-generated pollution.

The results showed that the PHH is not supported by data, i.e. China is not a pollution haven and the US is not a winner in terms of emissions. In the bilateral trade setting, China is gaining in terms of emissions, while the US is losing. In their trade with the ROW, China is still a winner, but the environmental effect of trade in the US is not clear in the case of $\mathrm{CO}_{2}$ and $\mathrm{SO}_{2}$ emissions, while in the case of $\mathrm{NO}_{\mathrm{x}}$ emissions the US was a loser in 1992 and became a winner in 1997. Over time, in US-China trade, benefits of China and losses of the US were decreasing, whereas in the world trade setting, China's benefits in terms of all pollutants were increasing and the US had a tendency to become a pollution haven.

We should also mention that for China an extra increase in trade with the ROW is less beneficial in terms of emissions than the same increase in bilateral trade with the US. In contrast, the US get dirtier in their trade with China rather than in their trade with the ROW, the overwhelming majority of which are rich countries.

The global affect of extra trade on the environment was computed in a world consisting of the US and China only. We found that trade in this two-country setting is beneficial in terms of all emissions. Taking into account the fact that carbon dioxide is the most prominent greenhouse gas (76\%) in the atmosphere that leads to the problem of global warming and world climate change (the so called "greenhouse effect"), we conclude that trade between the US and China as historically the world leading emitters 
of carbon dioxide is clearly beneficial for their environment at the global level, although these benefits are decreasing over time.

Because of the lack of data, the FEH was examined for the US only. We found positive and significant, but small, correlations between pollution intensities of production and capital intensities of US commodities. The empirical examination of the FEH in case of bilateral trade showed that the capital requirements of extra exports are less than those of extra imports in 1992, with the reverse true in 1997. That is the FEH prediction failed for 1992, but is supported by 1997 US trade data with China. Still the differences between the exports and imports capital requirements are relatively small. The FEH is not supported in case of trade of the US with the ROW.

Finally we integrated the results of the two tests for the US, and found that in the bilateral trade setting, export related pollution per million USD capital requirements is higher than import related pollution per million USD capital requirements. Thus taking the capital endowment effect into account, an extra increase in trade will make the US dirtier in their trade with China. The same conclusion is true in trade of the US with the ROW in the case of nitrogen. However, for $\mathrm{CO}_{2}$ and $\mathrm{SO}_{2}$ emissions for production generated pollution percentages of larger or equal to 30\% in 1992 and 60\% in 1997 the US is benefiting in terms of $\mathrm{CO}_{2}$ and $\mathrm{SO}_{2}$ pollution when we take capital endowment effect into account. Over time losses (benefits) in both bilateral and world trade settings are decreasing.

Both the PHH and the FEH can be viewed as the result of the Heckscher-Ohlin (HO) theory in international trade, and the empirical examination of both in this paper is very similar to Leontief's test of the HO theory (see Leontief, 1953, 1956). From this perspective, if we consider "emissions permits" as the third factor besides labor and capital, then one can notice that poor countries are relatively abundant in this third factor (see for detail discussion, e.g. Dietzenbacher and Mukhopadhyay, 2004). Therefore, according to the HO theory, the developing world, having comparative advantage in pollution-intensive goods, will specialize in dirty goods production that results in the PHH prediction. On the other hand, accepting the view that capital intensive goods are relatively pollution-intensive and developed nations are abundant in capital, again according to the HO theory rich countries will specialize in dirty goods production and 
become a pollution haven, instead of poor countries, which is consistent with the FEH prediction. However, our empirical work in this paper rejects both theories, which implies that explaining the trade of pollutants remains an unresolved puzzle. The PHH is not entirely consistent with data for the US and China, confirming the results of Dietzenbacher and Mukhopadhyay (2004) for India that led them to introduce the term "Green Leontief Paradox". Possible explanations for this might be the high transportation costs for multinationals in reallocating their dirty goods production to less developed countries, different impediments for home production enhancement in poor countries (e.g. high domestic taxes, unfavorable investment conditions, social and political instability, corruption, unfavorable geographic conditions for production and trade, etc.), high demand for fossil fuels embodied commodities in developed countries rather than in the developing world, etc. On the other hand, the FEH is rejected for the US in its trade with China in 1992 and with the ROW, confirming the famous Leontief paradox, although it holds in US-China trade in 1997. But the first results are sufficient to reject the FEH as well. Thus our empirical examination questions the FEH itself. We found that the correlation between capital intensity and pollution intensity of production is rather small, which would raise a reasonable doubt about the existence of the FEH. Or if the theory is correct, then we again encounter the famous Leontief Paradox that questions the credibility of the assumption that the US are indeed capital-abundant country. Of course, the availability of sectoral capital-stock data for China would have shed more light on this issue. 


\section{References}

Antweiler, Werner; Brian R. Copeland and M. Scott Taylor (2001), "Is Free Trade Good for the Environment?” American Economic Review, Vol. 91, No.4, pp. 877-908.

Chichilnisky G. (1994), "North-South Trade and the Global Environment," American Economic Review, Vol. 84, No.4, pp. 851-874.

Copeland, Brian R. and M. Scott Taylor (1995), "Trade and Transboundary Pollution," American Economic Review, Vol. 85, No.4, pp. 716-737.

Copeland, Brian R. and M. Scott Taylor (2003), Trade and the Environment: Theory and Evidence, Princeton, Princeton University Press.

Copeland, Brian R. and M. Scott Taylor (2004), "Trade, Growth and the Environment," Journal of Economic Literature, Vol. XLII, pp. 7-71.

Dean, Judith M. (2002), “Testing the Impact of Trade Liberalization on the Environment: Theory and Evidence," Canadian Journal of Economics, Vol. 35, No.4, pp. 819-42.

Department of National Economic Accounting, National Bureau of Statistics (1996), China's 1992 Input-Output Table (Zhongguo Touru Chanchu Biao 1992 Niandu), Beijing: China Statistical Publishing House.

Department of National Economic Accounting, National Bureau of Statistics (1999), China's 1997 Input-Output Table (Zhongguo Touru Chanchu Biao 1997 Niandu), Beijing: China Statistical Publishing House.

Di Maria, C., and S.A. Smulders (2004), “Trade Pessimists vs Technology Optimists: Induced Technical Change and Pollution Havens," Advances in Economic Analysis and Policy, Vol. 4, No. 2, Article 7.

Dietzenbacher, Erik and Kakali Mukhopadhyay (2004), “An Empirical Examination of the Pollution Haven Hypothesis for India: Towards a Green Leontief Paradox?" Presented in Input-Output and General Equilibrium: Data, Modeling and Policy Analysis, Brussels, Belgium.

Dietzenbacher, Erik; Albino, Vito and Silvana Kuhtz (2005), "The Fallacy of Using USType Input-Output Tables," Presented in Fifteenth International Input-Output Conference, Beijing, China. 
Duchin, Faye (2004), "International Trade: Evolution in the Thought and Analysis of Wassily Leontief," in M.L. Lahr and E. Dietzenbacher (eds.), Wassily Leontief and Input-Output Economics (Cambridge University Press, Cambridge), pp. 47-64.

Gay, W. Philip and John L.R. Proops (1993), "Carbon-dioxide Production by the UK Economy: An Input-Output Assessment," Applied Energy, Vol. 44, pp. 113-130.

Grossman, Gene M. and Alan B. Krueger (1993), "Environmental Impacts of a North American Free Trade Agreement," in Peter M. Garber (ed.), The US-Mexico Free Trade Agreement, Cambridge: MIT Press, pp. 13-56.

Harrigan, James (1997), “Technology, Factor Supplies, and International Specialization: Estimating the Neoclassical Model," American Economic Review, Vol. 87, No. 4, pp. $475-494$.

Hayami H.; M. Nakamura, M. Suga and K. Yoshioka (1997), "Environmental Management in Japan: Application of Input-Output Analysis to the Emission of Global Warming Gases," Managerial and Decision Economics, Vol. 18, No. 2, pp. 195-208.

International Energy Agency (2000), Energy Balances of Non-OECD countries, 19971998, France, OECD/IEA.

International Energy Agency (2000), Energy Balances of OECD countries, 1997-1998, France, OECD/IEA.

Lahr, Michael (2001), "Reconciling Domestication Techniques, the Notion of Re-exports and Some Comments on Regional Accounting," Economic Systems Research, Vol. 13, No. 2, pp. 165-179.

Lenzen, M. (2001), "A Generalized Input-Output Multiplier Calculus for Australia," Economic Systems Research, Vol.13, No.1, pp. 65-92.

Leontief, Wassily (1953), "Domestic Production and Foreign Trade: The American Capital Position Re-examined," Proceedings of the American Philosophical Society, Vol. 97, No. 4, pp. 332-349.

Leontief, Wassily (1956), "Factor Proportions and the Structure of American Trade: Furhter Theoretical and Empirical Analysis," Review of Economics and Statistics, Vol. 38, pp. 386-407. 
Leontief, Wassily (1966), Input - Output Economics, Second ed., New York, Oxford University Press.

Levinson, Arik and M. Scott Taylor (2002), "Trade and the Environment: Unmasking the Pollution Haven Effect," mimeo, Georgetown U.

Low, Patrick and Alexander Yeats (1992), “Do 'Dirty' Industries Migrate?" in International Trade and the Environment, Patrick Low, ed. Washington, DC: World Bank. pp. 89-104. Discuss. paper 159.

Lucas, Robert E.B.; David Wheeler and Hermamala Hettige (1992), "Economic Development, Environmental Regulation and the International Migration of Toxic Industrial Pollution: 1960-1988," in Patrick Low (ed.), International Trade and the Environment, Washington, DC, pp. 67-86. World Bank Discussion paper 159.

Machado, Giovani, Roberto Schaeffer \& Ernst Worrell (2001), "Energy and Carbon Embodied in the International Trade of Brazil: An Input-Output Approach," Ecological Economics, Vol. 39, Issue 3, pp. 409-424.

Mani, Muthikumara and David Wheeler (1997), "In Search of Pollution Havens? Dirty Industry Migration in the World Economy," World Bank working paper 16.

Miller, R.E. and P.D. Blair (1985), Input-Output Analysis: Foundations and Extensions, Englewood Cliffs, NJ, Prentice Hall.

Mukhopadhyay, Kakali and Osmo Forssell (2004), “An Empirical Investigation of Air Pollution from Fossil Fuel Combustion and its Impact on Health in India during 1973-1974 to 1996-1997," Ecological Economics, Vol. 55, Issue 2, pp. 235-250.

Proops, J.L.R., G. Atkinson, B. Frhr v. Schlotheim and S. Simon (1999), "International Trade and the Sustainability Footprint: A Practical Criterion for its Assessment," Ecological Economics, Vol. 28, pp. 75-97.

Taylor M. Scott (2004), "Unbundling the Pollution Haven Hypothesis," Advances in Economic Analysis and Policy, Vol. 4, No. 2, Article 8.

Tobey, James A. (1990), “The Effects of Domestic Environmental Policies on Patterns of World Trade: An Empirical Test,” Kyklos, Vol.43, No.2, pp. 191-209.

Trefler, Daniel (1993), “International Factor Price Differences: Leontief was Right!” Journal of Political Economy, Vol. 101, No. 6, pp. 961-987. 
Trefler, Daniel (1995), "The Case of Missing Trade and Other Misteries," American Economic Review, Vol. 85, No. 5, pp. 1029-1046.

Wilting, H.C. (1996), An Energy Perspective on Economic Activities, University of Groningen.

Wyckoff, W. Andrew and Joseph M. Roop (1994), "The Embodiment of Carbon in Imports of Manufactured Products: Implications for International Agreements on Greenhouse Gas Emissions," Energy Policy, Vol. 22, No. 3, pp 187-194.

Xu, Xinpeng (1999), "Do Stringent Environmental Regulations Reduce the International Competitiveness of Environmentally Sensitive Goods? A Global Perspective," World Development, Vol. 27, No.7, pp. 1215-1226. 
Table 2. The US emissions from one billions of USD of extra exports and imports, 1997

\begin{tabular}{|c|c|c|c|c|c|c|c|c|c|c|c|c|c|c|c|c|c|c|c|}
\hline \multirow{3}{*}{$\begin{array}{l}\text { Com- } \\
\text { modity } \\
\text { (1) }\end{array}$} & \multicolumn{4}{|c|}{ Trade of the US } & \multicolumn{5}{|c|}{$\mathrm{CO}_{2}$ emissions from the US trade } & \multicolumn{5}{|c|}{$\mathrm{SO}_{2}$ emissions from the US trade } & \multicolumn{5}{|c|}{$\mathrm{NO}_{\mathrm{x}}$ emissions from the US trade } \\
\hline & \multicolumn{2}{|c|}{ with the ROW } & \multicolumn{2}{|c|}{ with China } & \multirow[b]{2}{*}{$\begin{array}{l}\text { Mult. } \\
\text { (6) }\end{array}$} & \multicolumn{2}{|c|}{ with the ROW } & \multicolumn{2}{|c|}{ with China } & \multirow[b]{2}{*}{ Mult. } & \multicolumn{2}{|c|}{ with the ROW } & \multicolumn{2}{|c|}{ with China } & \multirow[b]{2}{*}{$\begin{array}{l}\text { Mult. } \\
\text { (16) }\end{array}$} & with th & ROW & with & China \\
\hline & $\begin{array}{l}\text { Export } \\
\text { (2) }\end{array}$ & $\begin{array}{c}\text { Import } \\
\text { (3) } \\
\end{array}$ & $\begin{array}{c}\text { Export } \\
\text { (4) } \\
\end{array}$ & $\begin{array}{c}\text { Import } \\
(5) \\
\end{array}$ & & $\begin{array}{c}\text { EP } \\
(7)= \\
(6) \times(2)\end{array}$ & $\begin{array}{c}\text { IP } \\
(8)= \\
(6) \times(3)\end{array}$ & $\begin{array}{c}\text { EP } \\
(9)= \\
(6) \times(4)\end{array}$ & $\begin{array}{c}\text { IP } \\
(10)= \\
(6) \times(5)\end{array}$ & & $\begin{array}{c}\mathrm{EP} \\
(12)= \\
(11) \times(2)\end{array}$ & $\begin{array}{c}\text { IP } \\
(13)= \\
(11) \times(3)\end{array}$ & $\begin{array}{c}\text { EP } \\
(14)= \\
(11) \times(4)\end{array}$ & $\begin{array}{c}\text { IP } \\
(15)= \\
(11) \times(5)\end{array}$ & & $\begin{array}{c}\text { EP } \\
(17)= \\
(16) \times(2)\end{array}$ & $\begin{array}{c}\text { IP } \\
(18)= \\
(16) \times(3)\end{array}$ & $\begin{array}{c}\text { EP } \\
(19)= \\
(16) \times(4)\end{array}$ & $\begin{array}{c}\text { IP } \\
(20)= \\
(16) \times(5)\end{array}$ \\
\hline 1 & 44.05 & 14.78 & 83.51 & 1.63 & 0.86 & 37.91 & 12.72 & 71.87 & 1.40 & 8.56 & 377.29 & 126.55 & 715.21 & 13.93 & 3.13 & 137.96 & 46.27 & 261.52 & 5.09 \\
\hline 2 & 1.73 & 2.79 & 0.98 & 0.66 & 0.91 & 1.58 & 2.54 & 0.90 & 0.60 & 8.39 & 14.56 & 23.42 & 8.26 & 5.57 & 5.76 & 9.98 & 16.06 & 5.66 & 3.82 \\
\hline 3 & 3.05 & 2.00 & 1.25 & 0.89 & 0.32 & 0.99 & 0.65 & 0.40 & 0.29 & 3.29 & 10.05 & 6.57 & 4.11 & 2.92 & 0.95 & 2.89 & 1.89 & 1.18 & 0.84 \\
\hline 4 & 3.87 & 7.95 & 9.99 & 4.97 & 0.65 & 2.50 & 5.15 & 6.47 & 3.22 & 6.49 & 25.10 & 51.63 & 64.87 & 32.28 & 2.19 & 8.47 & 17.41 & 21.88 & 10.89 \\
\hline 5 & 2.52 & 75.59 & 10.27 & 6.96 & 3.93 & 9.93 & 297.41 & 40.40 & 27.39 & 40.89 & 103.19 & 3090.50 & 419.83 & 284.61 & 7.94 & 20.03 & 599.80 & 81.48 & 55.24 \\
\hline 6 & 5.14 & 0.31 & 0.34 & 0.00 & 5.09 & 26.16 & 1.56 & 1.73 & 0.02 & 19.98 & 102.65 & 6.11 & 6.77 & 0.07 & 131.53 & 675.86 & 40.26 & 44.60 & 0.46 \\
\hline 7 & 3.99 & 3.09 & 2.26 & 3.10 & 1.05 & 4.19 & 3.25 & 2.38 & 3.26 & 9.61 & 38.32 & 29.70 & 21.74 & 29.84 & 6.94 & 27.67 & 21.45 & 15.70 & 21.55 \\
\hline 8 & 0.00 & 0.00 & 0.00 & 0.00 & 5.88 & 0.00 & 0.00 & 0.00 & 0.00 & 34.45 & 0.00 & 0.00 & 0.00 & 0.00 & 109.96 & 0.00 & 0.00 & 0.00 & 0.00 \\
\hline 9 & 0.00 & 0.00 & 0.00 & 0.00 & 10.50 & 0.00 & 0.00 & 0.00 & 0.00 & 110.87 & 0.00 & 0.00 & 0.00 & 0.00 & 14.81 & 0.00 & 0.00 & 0.00 & 0.00 \\
\hline 10 & $\begin{array}{l}0.00 \\
0.00\end{array}$ & 0.00 & 0.00 & 0.00 & $\begin{array}{l}1.50 \\
0.55\end{array}$ & $\begin{array}{l}0.00 \\
0.00\end{array}$ & $\begin{array}{l}0.00 \\
0.00\end{array}$ & $\begin{array}{l}0.00 \\
0.00\end{array}$ & 0.00 & $\begin{array}{c}110.28 \\
5.28\end{array}$ & 0.00 & 0.00 & 0.00 & $\begin{array}{l}0.00 \\
0.00\end{array}$ & $\begin{array}{l}1.81 \\
2.70\end{array}$ & $\begin{array}{l}0.00 \\
0.00\end{array}$ & $\begin{array}{l}0.00 \\
0.00\end{array}$ & 0.00 & 0.00 \\
\hline $\begin{array}{l}10 \\
11\end{array}$ & $\begin{array}{l}0.00 \\
39.68\end{array}$ & $\begin{array}{l}.0 .00 \\
19.92\end{array}$ & 41.55 & $\begin{array}{l}.00 \\
6.83\end{array}$ & 0.57 & 22.81 & $\begin{array}{l}0.00 \\
11.45\end{array}$ & $\begin{array}{l}0.00 \\
23.88\end{array}$ & $\begin{array}{l}.000 \\
3.93\end{array}$ & $\begin{array}{l}5.28 \\
5.23\end{array}$ & $\begin{array}{l}0.07 .74 \\
207.7\end{array}$ & $\begin{array}{c}0.00 \\
104.29\end{array}$ & $\begin{array}{r}0.00 \\
217.48\end{array}$ & $\begin{array}{l}0.00 \\
35.77\end{array}$ & 3.88 & $\begin{array}{l}0.00 \\
154.15\end{array}$ & $\begin{array}{l}.0 .00 \\
77.39\end{array}$ & $\begin{array}{l}0.00 \\
161.39\end{array}$ & $\begin{array}{l}0.00 \\
26.54\end{array}$ \\
\hline $\begin{array}{l}11 \\
12\end{array}$ & $\begin{array}{l}39.68 \\
2.61\end{array}$ & $\begin{array}{l}79.92 \\
7.11\end{array}$ & $\begin{array}{l}41.53 \\
0.28\end{array}$ & $\begin{array}{l}0.83 \\
0.15\end{array}$ & 0.35 & $\begin{array}{l}22.81 \\
0.92\end{array}$ & $\begin{array}{l}11.45 \\
2.50\end{array}$ & $\begin{array}{c}23.88 \\
0.10\end{array}$ & $\begin{array}{l}3.93 \\
0.05\end{array}$ & $\begin{array}{l}5.23 \\
3.04\end{array}$ & 7.92 & $\begin{array}{l}204.29 \\
21.59\end{array}$ & $\begin{array}{c}117.48 \\
0.85\end{array}$ & 0.46 & $\begin{array}{l}3.88 \\
2.97\end{array}$ & $\begin{array}{l}154.15 \\
7.75\end{array}$ & $\begin{array}{r}21.1 .14 \\
214\end{array}$ & $\begin{array}{c}101.39 \\
0.83\end{array}$ & $\begin{array}{l}26.54 \\
0.45\end{array}$ \\
\hline $\begin{array}{l}12 \\
13 \\
13\end{array}$ & $\begin{array}{l}2.61 \\
7.55\end{array}$ & $\begin{array}{l}.111 \\
0.59\end{array}$ & $\begin{array}{l}0.28 \\
0.22\end{array}$ & $\begin{array}{l}0.13 \\
0.01\end{array}$ & $\begin{array}{l}0.35 \\
0.25\end{array}$ & $\begin{array}{l}0.92 \\
1.91\end{array}$ & $\begin{array}{l}2.50 \\
0.15\end{array}$ & $\begin{array}{l}0.10 \\
0.06\end{array}$ & $\begin{array}{l}.03 \\
0.00\end{array}$ & $\begin{array}{l}3.04 \\
2.30\end{array}$ & $\begin{array}{l}1.92 \\
17.38\end{array}$ & $\begin{array}{l}21.59 \\
1.36\end{array}$ & $\begin{array}{l}0.85 \\
0.52\end{array}$ & $\begin{array}{l}0.46 \\
0.01\end{array}$ & $\begin{array}{l}2.91 \\
1.69\end{array}$ & 12.76 & $\begin{array}{l}21.14 \\
1.00\end{array}$ & $\begin{array}{l}0.83 \\
0.38\end{array}$ & $\begin{array}{l}0.43 \\
0.01\end{array}$ \\
\hline 14 & 11.74 & 13.34 & $\begin{array}{l}.22 \\
4.90\end{array}$ & $\begin{array}{l}0.01 \\
25.10\end{array}$ & 0.57 & 6.68 & $\begin{array}{l}.1 .13 \\
7.59\end{array}$ & 2.79 & 14.28 & 4.98 & 58.41 & $\begin{array}{l}1.50 \\
66.37\end{array}$ & 24.40 & 124.91 & 4.60 & 53.96 & 61.32 & 22.55 & $\begin{array}{l}0.01 \\
115.40\end{array}$ \\
\hline $\begin{array}{l}14 \\
15\end{array}$ & $\begin{array}{l}11.14 \\
16.85\end{array}$ & $\begin{array}{l}15 . .54 \\
79.35\end{array}$ & $\begin{array}{l}4.90 \\
4.85\end{array}$ & 268.71 & 0.32 & $\begin{array}{l}\text {.0.08 } \\
5.40\end{array}$ & 25.41 & 1.55 & $\begin{array}{l}14.28 \\
86.04\end{array}$ & 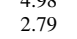 & $\begin{array}{l}58.41 \\
47.07\end{array}$ & 221.68 & $\begin{array}{l}24.40 \\
13.55\end{array}$ & $\begin{array}{l}124.91 \\
750.70\end{array}$ & 2.61 & 43.98 & 207.12 & 12.66 & 701.40 \\
\hline 16 & 8.33 & 15.38 & 2.90 & 7.30 & 0.39 & $\begin{array}{l}3.40 \\
3.24\end{array}$ & 5.99 & 1.13 & 2.84 & 3.47 & 28.86 & 53.31 & 10.06 & 25.31 & 2.93 & 24.36 & 44.99 & 8.49 & 21.36 \\
\hline 17 & 29.34 & 21.31 & 31.98 & 10.73 & 0.61 & 17.85 & 12.97 & 19.46 & 6.53 & 5.17 & 151.77 & 110.24 & 165.46 & 55.52 & 5.46 & 160.24 & 116.40 & 174.70 & 58.62 \\
\hline 18 & 10.86 & 15.51 & 7.65 & 0.60 & 16.35 & 177.49 & 253.51 & 125.07 & 9.87 & 172.85 & 1876.96 & 2680.91 & 1322.64 & 104.42 & 21.91 & 237.90 & 339.79 & 167.64 & 13.24 \\
\hline 19 & 38.93 & 22.59 & 29.50 & 10.49 & 1.90 & 74.10 & 43.01 & 56.16 & 19.97 & 18.82 & 732.45 & 425.12 & 555.15 & 197.37 & 7.39 & 287.61 & 166.93 & 217.99 & 77.50 \\
\hline 20 & 43.49 & 23.43 & 38.88 & 27.16 & 0.82 & 35.58 & 19.17 & 31.81 & 22.22 & 7.68 & 334.19 & 180.08 & 298.80 & 208.72 & 4.66 & 202.71 & 109.23 & 181.24 & 126.61 \\
\hline 21 & 7.41 & 3.01 & 84.60 & 0.11 & 1.90 & 14.08 & 5.71 & 160.62 & 0.22 & 19.23 & 142.60 & 57.79 & 1627.02 & 2.19 & 5.66 & 41.98 & 17.01 & 478.98 & 0.64 \\
\hline 22 & 16.12 & 16.71 & 3.68 & 3.64 & 0.26 & 4.16 & 4.31 & 0.95 & 0.94 & 2.33 & 37.54 & 38.92 & 8.58 & 8.47 & 1.82 & 29.37 & 30.45 & 6.72 & 6.63 \\
\hline 23 & 19.45 & 8.72 & 7.79 & 3.06 & 0.69 & 13.41 & 6.02 & 5.37 & 2.11 & 6.69 & 130.08 & 58.36 & 52.08 & 20.45 & 3.14 & 61.10 & 27.41 & 24.46 & 9.61 \\
\hline 24 & 9.68 & 12.48 & 13.01 & 22.73 & 0.83 & $\begin{array}{l}8.01 \\
\end{array}$ & 10.32 & 10.76 & 18.80 & 6.60 & 63.90 & 82.34 & 85.90 & 150.02 & 9.02 & 87.31 & 112.51 & 117.37 & 204.98 \\
\hline 25 & 8.50 & 19.30 & 3.95 & 6.39 & 2.20 & 18.69 & 42.47 & 8.69 & 14.07 & 11.22 & 95.33 & 216.62 & 44.33 & 71.76 & 47.32 & 401.96 & 913.41 & 186.93 & 302.57 \\
\hline 26 & 23.34 & 23.64 & 18.40 & 4.14 & 0.67 & 15.52 & 15.72 & $\begin{array}{l}0.093 \\
12.23\end{array}$ & 2.76 & 4.92 & 114.87 & 116.34 & 90.52 & 20.39 & 8.67 & 202.36 & 204.94 & 159.46 & 35.93 \\
\hline 27 & 25.18 & 23.59 & 13.15 & 29.40 & 0.45 & 11.29 & 10.58 & 5.90 & 13.18 & 3.22 & 81.00 & 75.92 & 42.33 & 94.58 & 6.22 & 156.52 & 146.69 & 81.79 & 182.76 \\
\hline 28 & 21.60 & 9.54 & 30.67 & 1.94 & 0.46 & 9.84 & 4.34 & 13.97 & 0.88 & 3.26 & 70. & 31. & 99.84 & 6.31 & 6.36 & 137.41 & 60.68 & 195.08 & 12.32 \\
\hline 29 & 8.59 & $\begin{array}{l}9.34 \\
10.29\end{array}$ & $\begin{array}{l}11.76 \\
11.76\end{array}$ & $\begin{array}{l}1.94 \\
1.70\end{array}$ & 0.33 & $\begin{array}{l}.04 \\
2.85\end{array}$ & $\begin{array}{l}4.54 \\
3.41\end{array}$ & 3.89 & 0.56 & $\begin{array}{l}3.20 \\
2.46\end{array}$ & 21. & 25. & 28.95 & $\begin{array}{l}.0 .31 \\
4.20\end{array}$ & $\begin{array}{l}4.3 \\
4.2\end{array}$ & 36.70 & $\begin{array}{l}0.00 \\
43.93\end{array}$ & 50.20 & 7.27 \\
\hline 30 & 98.11 & 59.48 & 123.29 & 42.25 & 0.38 & 37.22 & $\begin{array}{r}22.41 \\
22.57\end{array}$ & $\begin{array}{r}3.078 \\
46.78\end{array}$ & $\begin{array}{l}0.00 \\
16.03\end{array}$ & 2.89 & 283.75 & 172.03 & 356.60 & 122.20 & $\begin{array}{l}4.21 \\
4.63\end{array}$ & 454.42 & 275.49 & $\begin{array}{l}57.20 \\
571.08\end{array}$ & $\begin{array}{l}1.27 \\
195.71\end{array}$ \\
\hline $\begin{array}{l}30 \\
31\end{array}$ & $\begin{array}{l}98.11 \\
230.54\end{array}$ & $\begin{array}{r}59.48 \\
208.49\end{array}$ & 156.86 & $\begin{array}{l}42.25 \\
191.06\end{array}$ & $\begin{array}{l}0.38 \\
0.19\end{array}$ & $\begin{array}{r}71.22 \\
44.93\end{array}$ & 40.63 & $\begin{array}{l}40.18 \\
30.57\end{array}$ & $\begin{array}{l}10.03 \\
37.24\end{array}$ & $\begin{array}{l}1.89 \\
1.62\end{array}$ & 373.21 & $\begin{array}{l}112.03 \\
337.50\end{array}$ & $\begin{array}{r}530.00 \\
253.92\end{array}$ & $\begin{array}{l}309.20 \\
309.20\end{array}$ & 1. & $\begin{array}{r}\text { 554.42 } \\
435.52\end{array}$ & $\begin{array}{l}393.85 \\
\end{array}$ & 296.32 & 360.93 \\
\hline 32 & 34.56 & 32.61 & 27.39 & 80 & 0. & 14 & 13.56 & 11. & 33 & 3. & 115 & 108 & 91.48 & 268 & 4. & 15 & 145.16 & 12 & 357.35 \\
\hline 33 & 178.11 & $\begin{array}{c}5.01 \\
177.93\end{array}$ & 200.01 & 11 & 0. & 6 & 6 & 70. & 4. & & 492 & 49 & 552.94 & 32 & 3 & $\begin{array}{l}69 \\
69\end{array}$ & 6 & 78 & 45.89 \\
\hline 34 & 34.27 & 61.95 & 14 & 223 & 0. & $\begin{array}{l}02 \\
11\end{array}$ & 20 . & 4. & 72 & & $\begin{array}{l}992.40 \\
92.72\end{array}$ & 167 & 38.84 & $\begin{array}{l}52 \\
60\end{array}$ & & 106 & 191.78 & 44.44 & 693.06 \\
\hline 35 & 0.0 & 0.0 & 0. & 0. & 0. & & 0. & & 0. & & 0 & 0. & 0. & 0. & & 0 & 0 & & 0.00 \\
\hline 36 & 0.00 & 0.0 & 0.0 & 0. & 1.0 & 0. & 0. & 0. & 0. & 10.51 & 0 & 0 & 0. & & 2. & 0 & & & 0.00 \\
\hline 37 & 0.0 & 0. & & & 0. & & 0. & & & 1.18 & & 0. & & 0. & 1. & & & & 0.02 \\
\hline 38 & 0.0 & & & & 0. & & 0. & & & & & & & & & & & & 0.00 \\
\hline 39 & 0.6 & 0. & 0. & & 0. & & 0. & & & & 0 & & 0 & 0. & 1. & 0 & 0 & 0.00 & 0.00 \\
\hline 40 & 0.00 & 0. & 0. & 0. & 0. & 0. & 0. & 0. & & & 0. & 0 & 0. & 0. & 1.5 & 0. & 0. & 0.00 & 0.00 \\
\hline 41 & 0.00 & 0.0 & 0.0 & 0. & 0.35 & 0. & 0.0 & 0.0 & 0. & 3. & 0. & 0. & 0. & 0. & 3.11 & 0.0 & 0. & 0.00 & 0.00 \\
\hline 42 & 0.00 & 0.00 & 0.00 & 0. & 0.22 & 0.00 & 0.00 & 0.00 & 0.00 & 1.79 & 0.00 & 0.0 & 0. & 0.00 & 2.08 & 0.0 & 0.00 & 0.00 & 0.00 \\
\hline 43 & 0.00 & 0.00 & 0.00 & 0.00 & 0.13 & 0.00 & 0.00 & 0.00 & 0.00 & 1.10 & 0.00 & 0.00 & 0.00 & 0.00 & 1.05 & 0.00 & 0.00 & 0.00 & 0.00 \\
\hline 44 & 0.00 & 0.00 & 0.00 & 0.00 & 0.24 & 0.00 & 0.00 & 0.00 & 0.00 & 2.01 & 0.00 & 0.00 & 0.0 & 0.00 & 2.29 & 0.00 & 0.00 & 0.00 & 0.00 \\
\hline 45 & 0.00 & 0.00 & 0.00 & 0.00 & 0.23 & 0.00 & 0.00 & 0.00 & 0.00 & 2.04 & 0.00 & 0.00 & 0.00 & 0.00 & 1.67 & 0.00 & 0.00 & 0.00 & 0.00 \\
\hline 46 & 10.83 & 6.99 & 19.76 & 2.40 & 0.00 & 0.00 & 0.00 & 0.00 & 0.00 & 0.00 & 0.00 & 0.00 & 0.00 & 0.00 & 0.00 & 0.00 & 0.00 & 0.00 & 0.00 \\
\hline Total & 1000.00 & 1000.00 & 1000.00 & 1000.00 & & 697.05 & 967.05 & 771.96 & 418.77 & & 6248.22 & 9180.38 & 7223.03 & 3588.53 & & 5071.00 & 5149.50 & 4498.61 & 3654.66 \\
\hline
\end{tabular}

Notes: Exports $(2,4)$ and imports $(3,5)$ are in millions of USD with their total of one billions of USD. Multipliers (denoted Mult.) in (6) are in thousands tons of $\mathrm{CO}_{2}$ per millions of USD of final demand for commodity $j$. Multipliers in (11) and (16) are in tons of $\mathrm{SO}_{2}$ and $\mathrm{NO}_{\mathrm{x}}$ per millions of USD of final demand. EP and IP stand for export pollution and import pollution, respectively. The pollution in (7)-(10) is expressed in thousands tons, the pollution in (12)-(15) and (17)-(20) is in tons. 
Table 3. China's emissions from one billions of RMB of extra exports and imports, 1997

\begin{tabular}{|c|c|c|c|c|c|c|c|c|c|c|c|c|c|c|c|c|c|c|c|}
\hline \multirow{3}{*}{$\begin{array}{l}\begin{array}{c}\text { Com- } \\
\text { modity }\end{array} \\
\text { (1) }\end{array}$} & \multicolumn{4}{|c|}{ Trade of China } & \multicolumn{5}{|c|}{$\mathrm{CO}_{2}$ emissions from China's trade } & \multicolumn{5}{|c|}{$\mathrm{SO}_{2}$ emissions from China's trade } & \multicolumn{5}{|c|}{$\mathrm{NO}_{\mathrm{x}}$ emissions from China's trade } \\
\hline & \multicolumn{2}{|c|}{ with the ROW } & \multicolumn{2}{|c|}{ with the US } & \multirow[b]{2}{*}{$\begin{array}{c}\text { Mult. } \\
\text { (6) }\end{array}$} & \multicolumn{2}{|c|}{ with the ROW } & \multicolumn{2}{|c|}{ with the US } & \multirow[b]{2}{*}{ Mult. } & \multicolumn{2}{|c|}{ with the ROW } & \multicolumn{2}{|c|}{ with the US } & \multirow[b]{2}{*}{ Mult. } & with th & ROW & with & e US \\
\hline & $\begin{array}{c}\text { Export } \\
\text { (2) } \\
\end{array}$ & $\begin{array}{c}\text { Import } \\
(3) \\
\end{array}$ & $\begin{array}{c}\text { Export } \\
(4) \\
\end{array}$ & $\begin{array}{c}\text { Import } \\
(5) \\
\end{array}$ & & $\begin{array}{c}\text { EP } \\
(7)= \\
(6) \times(2)\end{array}$ & $\begin{array}{c}\text { IP } \\
(8)= \\
(6) \times(3)\end{array}$ & $\begin{array}{c}\text { EP } \\
(9)= \\
(6) \times(4)\end{array}$ & $\begin{array}{c}\text { IP } \\
(10)= \\
(6) \times(5)\end{array}$ & & $\begin{array}{c}\mathrm{EP} \\
(12)= \\
(11) \times(2)\end{array}$ & $\begin{array}{c}\text { IP } \\
(13)= \\
(11) \times(3)\end{array}$ & $\begin{array}{c}\text { EP } \\
(14)= \\
(11) \times(4)\end{array}$ & $\begin{array}{c}\text { IP } \\
(15)= \\
(11) \times(5)\end{array}$ & & $\begin{array}{c}\text { EP } \\
(17)= \\
(16) \times(2)\end{array}$ & $\begin{array}{c}\mathrm{IP} \\
(18)= \\
(16) \times(3)\end{array}$ & $\begin{array}{c}E P \\
(19)= \\
(16) \times(4)\end{array}$ & $\begin{array}{c}\text { IP } \\
(20)= \\
(16) \times(5)\end{array}$ \\
\hline 1 & 16.09 & 22.30 & 1.63 & 83.51 & 0.16 & 2.51 & 3.48 & 0.25 & 13.02 & 0.88 & 14.11 & 19.57 & 1.43 & 73.27 & 3.05 & 49.08 & 68.04 & 4.96 & 254.76 \\
\hline 2 & 4.27 & 3.87 & 0.66 & 0.98 & 0.10 & 0.41 & 0.37 & 0.06 & 0.10 & 0.53 & 2.28 & 2.07 & 0.36 & 0.53 & 1.93 & 8.26 & 7.47 & 1.28 & 1.90 \\
\hline 3 & 2.03 & 9.31 & 0.89 & 1.25 & 0.11 & 0.21 & 0.98 & 0.09 & 0.13 & 0.60 & 1.23 & 5.62 & 0.54 & 0.75 & 2.01 & 4.08 & 18.71 & 1.78 & 2.51 \\
\hline 4 & 2.54 & 0.41 & 4.97 & 9.99 & 0.13 & 0.33 & 0.05 & 0.65 & 1.30 & 0.82 & 2.08 & 0.33 & 4.07 & 8.18 & 2.22 & 5.64 & 0.91 & 11.05 & 22.20 \\
\hline 5 & 14.23 & 35.81 & 6.96 & 10.27 & 0.19 & 2.65 & 6.66 & 1.29 & 1.91 & 1.10 & $\begin{array}{l}15.59 \\
159\end{array}$ & 39.25 & 7.63 & $\begin{array}{l}0.10 \\
11.25\end{array}$ & 3.46 & 49.20 & 123.87 & 24.08 & 35.52 \\
\hline 6 & 4.18 & 0.63 & 0.00 & 0.34 & 0.38 & 1.57 & 0.24 & 0.00 & 0.13 & $\begin{array}{l}1.60 \\
1.60\end{array}$ & 6.67 & 1.00 & 0.01 & 0.54 & 9.23 & 38.59 & 5.80 & 0.03 & 3.13 \\
\hline 7 & $\begin{array}{l}4.10 \\
4.90\end{array}$ & $\begin{array}{l}.035 \\
19.25\end{array}$ & 3.10 & 2.26 & 0.31 & 1.54 & 6.06 & 0.98 & 0.71 & $\begin{array}{l}1.80 \\
1.81\end{array}$ & $\begin{array}{l}8.078 \\
8.88\end{array}$ & 34.86 & 5.62 & 4.09 & 6.01 & 29.46 & 115.68 & 18.65 & 13.59 \\
\hline 8 & 2.31 & 0.01 & 0.00 & 0.00 & 1.40 & 3.23 & 0.02 & 0.00 & 0.00 & 5.53 & 12.77 & 0.08 & 0.00 & 0.00 & 35.93 & 82.95 & 0.54 & 0.00 & 0.00 \\
\hline 9 & 0.00 & 0.00 & 0.00 & 0.00 & 1.09 & 0.00 & 0.00 & 0.00 & 0.00 & 4.41 & 0.00 & 0.00 & 0.00 & 0.00 & 27.49 & 0.00 & 0.00 & 0.00 & 0.00 \\
\hline 10 & 1.48 & 3.93 & 0.00 & 0.00 & 0.33 & 0.49 & 1.30 & 0.00 & 0.00 & 1.81 & 2.68 & 7.12 & 0.00 & 0.00 & 6.63 & 9.80 & 26.04 & 0.00 & 0.00 \\
\hline 11 & 36.75 & 34.12 & 6.83 & 41.55 & 0.15 & 5.60 & 5.20 & 1.04 & 6.33 & 0.79 & 29.21 & 27.12 & 5.43 & 33.02 & 3.21 & 118.11 & 109.65 & 21.96 & 133.52 \\
\hline 12 & 4.68 & 1.08 & 0.15 & 0.28 & 0.19 & 0.90 & 0.21 & 0.03 & 0.05 & 0.92 & 4.31 & 1.00 & 0.14 & 0.26 & 4.34 & 20.32 & 4.71 & 0.66 & 1.22 \\
\hline 13 & 2.89 & 1.68 & 0.01 & 0.22 & 0.08 & 0.24 & 0.14 & 0.00 & 0.02 & 0.42 & 1.22 & 0.71 & 0.00 & 0.09 & 1.77 & 5.10 & 2.97 & 0.01 & 0.40 \\
\hline 14 & 103.46 & 68.50 & 25.10 & 4.90 & 0.15 & 15.66 & 10.37 & 3.80 & 0.74 & 0.75 & 77.66 & 51.41 & 18.84 & 3.68 & 3.34 & 345.16 & 228.52 & 83.75 & 16.36 \\
\hline 15 & 130.33 & 25.95 & 268.71 & 4.85 & 0.12 & 15.03 & 2.99 & 30.98 & 0.56 & 0.60 & 78.26 & 15.59 & 161.36 & 2.91 & 2.43 & 316.96 & 63.12 & 653.51 & 11.80 \\
\hline 16 & 17.80 & 9.29 & 7.30 & 2.90 & 0.21 & 3.73 & 1.95 & 1.53 & 0.61 & 1.04 & 18.44 & 9.63 & 7.57 & 3.01 & 4.63 & 82.45 & 43.03 & 33.83 & 13.45 \\
\hline 17 & 4.13 & 28.23 & 10.73 & 31.98 & 0.23 & 0.96 & 6.54 & 2.49 & 7.41 & 1.09 & 4.52 & 30.90 & 11.75 & 35.02 & 5.30 & 21.90 & 149.62 & 56.89 & 169.54 \\
\hline 18 & 10.76 & 30.92 & 0.60 & 7.65 & 2.06 & 22.12 & 63.60 & 1.24 & 15.74 & 19.02 & 204.62 & 588.20 & 11.49 & 145.55 & 12.81 & 137.78 & 396.06 & 7.74 & 98.01 \\
\hline 19 & 16.46 & 29.88 & 10.49 & 29.50 & 0.59 & 9.64 & 17.51 & 6.15 & 17.29 & 3.80 & 62.46 & 113.42 & $\begin{array}{l}39.82 \\
39.4\end{array}$ & 111.99 & 9.63 & 158.47 & 287.76 & 101.02 & 284.13 \\
\hline 20 & 44.98 & 44.18 & 27.16 & 38.88 & 0.28 & 12.60 & 12.37 & 7.61 & 10.89 & 1.55 & 69.53 & 68.29 & 41.99 & 60.11 & 5.59 & $\begin{array}{l}251.33 \\
253\end{array}$ & 246.85 & 151.76 & 217.25 \\
\hline 21 & 2.41 & 20.71 & 0.11 & 84.60 & 0.83 & 1.99 & 17.09 & 0.09 & 69.81 & 4.32 & 10.41 & 89.51 & 0.49 & 365.66 & 17.33 & 41.74 & 358.88 & 1.97 & 1466.01 \\
\hline 22 & 6.16 & 2.30 & 3.64 & 3.68 & 0.18 & 1.08 & 0.40 & 0.64 & 0.65 & 0.90 & 5.56 & 2.08 & 3.28 & 3.33 & 3.73 & 23.00 & 8.59 & 13.57 & 13.75 \\
\hline 23 & $\begin{array}{l}0.10 \\
21.53\end{array}$ & 68.54 & 3.06 & $\begin{array}{l}7.06 \\
7.79\end{array}$ & 0.48 & $\begin{array}{l}10.35 \\
10.35\end{array}$ & 32.95 & $\begin{array}{l}1.04 \\
1.47\end{array}$ & 3.74 & 2.74 & 58.90 & 187.46 & $\begin{array}{l}.2 .20 \\
8.36\end{array}$ & 21.30 & 9.30 & 200.16 & 637.08 & 28.42 & 72.38 \\
\hline 24 & $\begin{array}{l}18.11 \\
18.11\end{array}$ & $\begin{array}{l}08.54 \\
8.33\end{array}$ & $\begin{array}{l}32.00 \\
22.73\end{array}$ & 13.01 & $\begin{array}{l}0.48 \\
0.57\end{array}$ & $\begin{array}{l}10.035 \\
10.35\end{array}$ & 4.76 & $\begin{array}{l}1.47 \\
13.00\end{array}$ & $\begin{array}{l}3.14 \\
7.44\end{array}$ & 2.54 & $\begin{array}{l}58.90 \\
45.93\end{array}$ & 21.12 & $\begin{array}{l}8.00 \\
57.66\end{array}$ & $\begin{array}{l}21.30 \\
33.02\end{array}$ & $\begin{array}{l}9.30 \\
13.69\end{array}$ & $\begin{array}{l}240.10 \\
247.92\end{array}$ & $\begin{array}{l}114.00 \\
114.00\end{array}$ & $\begin{array}{l}28.42 \\
311.23\end{array}$ & $\begin{array}{l}17.38 \\
178.20\end{array}$ \\
\hline 25 & $\begin{array}{l}10.11 \\
17.83\end{array}$ & $\begin{array}{l}0.53 \\
38.48\end{array}$ & 6.39 & 3.95 & 0.61 & 10.81 & $\begin{array}{l}.4 .10 \\
23.33\end{array}$ & 3.88 & $\begin{array}{l}1.44 \\
2.40\end{array}$ & 3.14 & 56.03 & 120.95 & 20.10 & 12.42 & 12.85 & $\begin{array}{l}229.09 \\
229\end{array}$ & $\begin{array}{l}494.53 \\
494\end{array}$ & 82.18 & 50.77 \\
\hline 26 & 11.49 & 25.91 & 4.14 & 18.40 & 0.39 & 4.44 & 10.01 & 1.60 & 7.10 & 1.90 & 21.78 & 49.11 & 7.85 & 34.86 & 8.58 & 98.60 & 222.36 & 35.56 & 157.85 \\
\hline 27 & 39.32 & 26.26 & 29.40 & 13.15 & 0.34 & 13.45 & 8.98 & 10.06 & 4.50 & 1.75 & 68.61 & 45.82 & 51.30 & 22.96 & 7.36 & 289.22 & 193.15 & 216.23 & 96.77 \\
\hline 28 & 2.25 & 13.42 & 1.94 & 30.67 & 0.24 & 0.53 & 3.16 & 0.46 & 7.22 & 1.26 & 2.84 & 16.94 & 2.45 & 38.71 & 4.84 & 10.90 & 64.98 & 9.38 & 148.47 \\
\hline 29 & 1.92 & 14.37 & 1.70 & 11.76 & 0.26 & 0.49 & 3.69 & 0.44 & 3.02 & 1.37 & 2.63 & 19.65 & 2.33 & 16.08 & 5.31 & 10.20 & 76.26 & 9.04 & 62.39 \\
\hline 30 & 25.02 & 110.05 & 42.25 & 123.29 & 0.26 & 6.46 & 28.43 & 10.91 & 31.85 & 1.33 & 33.28 & 146.39 & 56.20 & 164.00 & 5.51 & 137.73 & $\begin{array}{l}10.20 \\
605.92\end{array}$ & 232.64 & 678.84 \\
\hline 31 & 107.74 & 133.03 & 191.06 & 156.86 & 0.15 & 16.67 & 20.58 & 29.56 & 24.27 & 0.82 & 88.40 & 109.15 & 156.76 & 128.70 & 3.21 & 345.97 & 427.17 & 613.51 & 503.68 \\
\hline 32 & 53.64 & 40.38 & 80.27 & 27.39 & 0.26 & 13.71 & 10.32 & 20.52 & 7.00 & 1.35 & 72.58 & 54.64 & 108.62 & 37.06 & 5.32 & 285.22 & 214.71 & 426.85 & 145.64 \\
\hline 33 & 18.79 & 37.38 & 11.71 & 200.01 & 0.23 & 4.36 & 8.67 & 2.71 & 46.38 & 1.23 & 23.02 & 45.81 & 14.35 & 245.11 & 4.83 & 90.77 & 180.60 & 56.56 & 966.33 \\
\hline 34 & 86.41 & 43.41 & 223.87 & 14.36 & 0.22 & 18.70 & 9.39 & 48.45 & 3.11 & 1.09 & 94.57 & 47.51 & 245.00 & 15.71 & 4.69 & 405.00 & 203.46 & 1049.28 & 67.28 \\
\hline 35 & 71.15 & 0.00 & 0.00 & 0.00 & 0.14 & 9.63 & 0.00 & 0.00 & 0.00 & 0.80 & 57.00 & 0.00 & 0.00 & 0.00 & 2.50 & 177.99 & 0.00 & 0.00 & 0.00 \\
\hline 36 & 28.69 & 6.69 & 0.00 & 0.00 & 0.32 & 9.28 & 2.16 & 0.00 & 0.00 & 2.43 & 69.60 & 16.22 & 0.00 & 0.00 & 4.10 & 117.66 & 27.42 & 0.00 & 0.00 \\
\hline 37 & 6.70 & 1.90 & 0.01 & 0.00 & 0.13 & 0.89 & 0.25 & 0.00 & 0.00 & 0.70 & 4.69 & 1.33 & 0.01 & 0.00 & 2.76 & 18.50 & 5.23 & 0.04 & 0.00 \\
\hline 38 & 1.02 & 3.45 & 0.00 & 0.00 & 0.08 & 0.09 & 0.29 & 0.00 & 0.00 & 0.46 & 0.47 & 1.58 & 0.00 & 0.00 & 1.70 & 1.73 & 5.86 & 0.00 & 0.00 \\
\hline 39 & 4.96 & 0.00 & 0.00 & 0.00 & 0.15 & 0.75 & 0.00 & 0.00 & 0.00 & 0.71 & 3.52 & 0.00 & 0.00 & 0.00 & 3.44 & 17.06 & 0.00 & 0.00 & 0.00 \\
\hline 40 & 11.85 & 11.13 & 0.00 & 0.00 & 0.24 & 2.84 & 2.67 & 0.00 & 0.00 & 1.27 & 15.00 & 14.09 & 0.00 & 0.00 & 4.99 & 59.08 & 55.50 & 0.00 & 0.00 \\
\hline 41 & 14.38 & 10.73 & 0.00 & 0.00 & 0.14 & 1.99 & 1.49 & 0.00 & 0.00 & $\begin{array}{l}1.67 \\
0.69\end{array}$ & 9.92 & 7.40 & 0.00 & 0.00 & 3.04 & 43.71 & 32.61 & 0.00 & 0.00 \\
\hline 42 & 9.23 & 1.39 & 0.00 & 0.00 & 0.13 & 1.16 & 0.17 & 0.00 & 0.00 & 0.62 & 5.74 & 0.86 & 0.00 & 0.00 & 2.77 & 25.61 & 3.86 & 0.00 & 0.00 \\
\hline 43 & 0.00 & 0.00 & 0.00 & 0.00 & 0.14 & 0.00 & 0.00 & 0.00 & 0.00 & 0.73 & 0.00 & $\begin{array}{l}0.00 \\
0.00\end{array}$ & 0.00 & 0.00 & 3.11 & 0.00 & $\begin{array}{l}.00 \\
0.00\end{array}$ & 0.00 & 0.00 \\
\hline 44 & 0.33 & $\begin{array}{l}.00 \\
1.59\end{array}$ & 0.00 & 0.00 & 0.18 & 0.06 & 0.28 & 0.00 & 0.00 & 0.99 & 0.32 & 1.57 & 0.00 & 0.00 & 3.52 & 1.15 & 5.59 & 0.00 & 0.00 \\
\hline 45 & 14.83 & $\begin{array}{r}11.59 \\
11.21\end{array}$ & 0.00 & $\begin{array}{l}0.00 \\
0.00\end{array}$ & $\begin{array}{l}0.18 \\
0.17\end{array}$ & $\begin{array}{l}2.00 \\
2.45\end{array}$ & $\begin{array}{l}.28 \\
1.86\end{array}$ & $\begin{array}{l}0.00 \\
0.00\end{array}$ & $\begin{array}{l}0.00 \\
0.00\end{array}$ & 1.00 & $\begin{array}{l}.3 .52 \\
14.85\end{array}$ & $\begin{array}{l}11.23 \\
11.23\end{array}$ & 0.00 & $\begin{array}{l}0.00 \\
0.00\end{array}$ & $\begin{array}{l}5.52 \\
2.98\end{array}$ & $\begin{array}{l}1.13 \\
44.20\end{array}$ & 33.42 & 0.00 & $\begin{array}{l}0.00 \\
0.00\end{array}$ \\
\hline 46 & 0.00 & 0.00 & 2.40 & 19.76 & 0.00 & 0.00 & 0.00 & 0.00 & 0.00 & 0.00 & 0.00 & 0.00 & 0.00 & 0.00 & 0.00 & 0.00 & 0.00 & 0.00 & 0.00 \\
\hline Total & 1000.00 & 1000.00 & 1000.00 & 1000.00 & & 241.94 & 330.96 & 201.98 & 295.42 & & 1382.18 & 2026.59 & 1052.80 & 1633.17 & & 4656.84 & 5870.53 & 4259.42 & 5887.65 \\
\hline
\end{tabular}


Table 8. The US capital requirements for satisfaction of one billion of USD of extra exports and imports in their trade with China

\begin{tabular}{|c|c|c|c|c|c|c|c|c|c|c|c|}
\hline \multicolumn{6}{|c|}{1992} & \multicolumn{6}{|c|}{1997} \\
\hline \multirow{2}{*}{$\begin{array}{c}\text { Com- } \\
\text { modity } \\
(1) \\
\end{array}$} & \multirow{2}{*}{$\begin{array}{c}\text { Direct } \\
\text { capital } \\
\text { coefficients } \\
(2)\end{array}$} & \multicolumn{2}{|c|}{$\begin{array}{l}\text { Direct and indirect capital } \\
\text { requirements based on the technology }\end{array}$} & \multicolumn{2}{|c|}{$\begin{array}{l}\text { Capital requirements } \\
\text { for satisfaction of extra }\end{array}$} & \multirow{2}{*}{$\begin{array}{l}\text { Com- } \\
\text { modity } \\
(7)\end{array}$} & \multirow{2}{*}{$\begin{array}{c}\text { Direct } \\
\text { capital } \\
\text { coefficients } \\
(8)\end{array}$} & \multicolumn{2}{|c|}{$\begin{array}{l}\text { Direct and indirect capital } \\
\text { requirements based on the technology }\end{array}$} & \multicolumn{2}{|c|}{$\begin{array}{l}\text { Capital requirements } \\
\text { for satisfaction of extra }\end{array}$} \\
\hline & & $\begin{array}{c}\text { of the US } \\
\text { (3) }\end{array}$ & $\begin{array}{c}\text { of China } \\
(4)\end{array}$ & $\begin{array}{c}\text { exports } \\
(5)\end{array}$ & $\begin{array}{c}\text { imports } \\
(6)\end{array}$ & & & $\begin{array}{c}\text { of the US } \\
\text { (9) }\end{array}$ & $\begin{array}{c}\text { of China } \\
(10)\end{array}$ & $\begin{array}{c}\text { exports } \\
(11)\end{array}$ & $\begin{array}{c}\text { imports } \\
(12)\end{array}$ \\
\hline 1 & 1.3803 & 2.7601 & 2.0136 & 185.724 & 5.189 & 1 & 1.2737 & 2.7826 & 2.0443 & 232.375 & 3.326 \\
\hline 2 & 1.6145 & 3.7359 & 2.5194 & 5.545 & 2.974 & 2 & 1.6292 & 3.9384 & 2.5733 & 3.873 & 1.709 \\
\hline 3 & 0.9819 & 1.8832 & 1.4224 & 33.125 & 0.751 & 3 & 0.4757 & 1.1487 & 0.9774 & 1.433 & 0.867 \\
\hline 4 & 0.3909 & 1.3342 & 0.9488 & 3.835 & 15.751 & 4 & 0.6257 & 1.6366 & 1.3174 & 16.351 & 6.550 \\
\hline 5 & 3.0433 & 5.3397 & 3.7449 & 0.049 & 62.154 & 5 & 4.6401 & 6.9681 & 5.1703 & 71.550 & 35.990 \\
\hline 6 & 2.6563 & 3.6969 & 3.7895 & 2.446 & 0.005 & 6 & 3.8039 & 5.1837 & 4.8017 & 1.758 & 0.017 \\
\hline 7 & 1.5594 & 2.6063 & 2.7591 & 11.115 & 4.948 & 7 & 0.8071 & 1.8057 & 2.0033 & 4.083 & 6.218 \\
\hline 8 & 1.3814 & 2.1819 & 2.7026 & 0.000 & 0.000 & 8 & 1.4028 & 2.3400 & 3.0698 & 0.000 & 0.000 \\
\hline 9 & 3.6926 & 5.7409 & 4.8840 & 0.000 & 0.000 & 9 & 5.6878 & 6.9929 & 7.6294 & 0.000 & 0.000 \\
\hline 10 & 0.1206 & 0.8536 & 1.4698 & 0.000 & 0.000 & 10 & 0.1729 & 1.0400 & 1.5415 & 0.000 & 0.000 \\
\hline 11 & 0.2357 & 1.7914 & 1.7906 & 8.792 & 15.171 & 11 & 0.1362 & 1.9487 & 1.6407 & 80.961 & 11.211 \\
\hline 12 & 1.1998 & 1.7934 & 2.0168 & 2.646 & 0.523 & 12 & 0.8567 & 1.9388 & 2.1705 & 0.544 & 0.332 \\
\hline 13 & 0.4756 & 1.4580 & 1.8723 & 10.601 & 80.949 & 13 & 1.3601 & 2.3065 & 2.1959 & 0.517 & 0.012 \\
\hline 14 & 0.1509 & 0.9466 & 1.5324 & 1.972 & 585.177 & 14 & 0.4947 & 1.6337 & 1.7236 & 8.012 & 43.267 \\
\hline 15 & 0.1770 & 0.9919 & 1.4234 & 1.052 & 12.921 & 15 & 0.1958 & 1.1009 & 1.2698 & 5.341 & 341.212 \\
\hline 16 & 0.5157 & 1.3823 & 1.7537 & 29.855 & 15.571 & 16 & 0.3260 & 1.2678 & 1.4868 & 3.681 & 10.858 \\
\hline 17 & 0.5266 & 3.4357 & 2.6110 & 91.240 & 4.432 & 17 & 0.6229 & 1.6824 & 1.7704 & 53.811 & 19.001 \\
\hline 18 & 0.6726 & 2.0224 & 2.2369 & 86.086 & 21.986 & 18 & 0.5236 & 3.3655 & 3.1860 & 25.752 & 1.925 \\
\hline 19 & 0.2593 & 1.2428 & 1.4223 & 46.406 & 36.950 & 19 & 0.7950 & 2.3774 & 2.4354 & 70.143 & 25.546 \\
\hline 20 & $\begin{array}{l}1.4239 \\
\text { n }\end{array}$ & 2.8500 & 2.9379 & 248.077 & 0.344 & 20 & 0.2606 & 1.3444 & $\begin{array}{l}1.4463 \\
\end{array}$ & 52.274 & 39.283 \\
\hline 21 & 0.4078 & $\begin{array}{l}1.0058 \\
1.000\end{array}$ & 1.6662 & 4.341 & 6.043 & 21 & $\begin{array}{l}1.3416 \\
\text { a }\end{array}$ & $\begin{array}{l}2.7315 \\
\end{array}$ & 3.1426 & 231.089 & 0.358 \\
\hline 22 & 0.4627 & $\begin{array}{l}1.3275 \\
1.02\end{array}$ & $\begin{array}{l}1.7596 \\
\text { n }\end{array}$ & 7.019 & $\begin{array}{l}0.0730 \\
.890\end{array}$ & 22 & 0.3857 & 1.3560 & $\begin{array}{l}1.5123 \\
1.5120\end{array}$ & 4.997 & 5.499 \\
\hline 23 & 0.7151 & 1.7879 & 2.0430 & 9.357 & 31.211 & 23 & 0.2891 & 1.3306 & 1.6502 & 10.360 & 5.045 \\
\hline 24 & 1.0146 & 2.2427 & 2.5545 & 21.331 & 5.083 & 24 & 0.5788 & 1.6052 & 2.0186 & 20.889 & 45.879 \\
\hline 25 & 0.5786 & 1.7634 & 2.1635 & 47.252 & 9.564 & 25 & 1.0106 & 2.2952 & 2.7886 & 9.067 & 17.832 \\
\hline 26 & 0.6442 & 1.5184 & 2.2117 & 13.633 & 61.443 & 26 & 0.3569 & 1.3626 & 1.8019 & 25.065 & 7.468 \\
\hline 27 & 0.2605 & 1.3412 & 1.5098 & 20.754 & 2.957 & 27 & 0.4853 & 1.3319 & 2.1132 & 17.521 & 62.119 \\
\hline 28 & 1.4549 & 2.2086 & 2.6377 & 34.631 & 3.456 & 28 & 0.1921 & 1.0814 & 1.3198 & 33.161 & 2.557 \\
\hline 29 & 0.2083 & 1.0473 & 1.4715 & 100.375 & 29.129 & 29 & 1.7556 & 2.6042 & 2.9995 & 30.615 & 5.109 \\
\hline 30 & 0.6595 & 1.3547 & 1.8050 & 170.456 & 191.342 & 30 & 0.2813 & 1.1790 & 1.4705 & 145.361 & 62.131 \\
\hline 31 & 0.3985 & 1.1969 & 1.7008 & 17.840 & 113.925 & 31 & 0.4626 & 1.2768 & 1.4260 & 200.275 & 272.450 \\
\hline 32 & 0.2983 & 1.2207 & 1.4357 & 386.435 & 12.773 & 32 & 0.3887 & 1.2646 & 1.6947 & 34.635 & 136.031 \\
\hline 33 & 0.2493 & 0.8756 & 1.4865 & 9.256 & 306.894 & 33 & 0.2741 & 1.1980 & 1.4586 & 239.608 & 17.076 \\
\hline 34 & 0.5512 & 1.2774 & 1.8722 & 0.000 & 0.000 & 34 & 0.3212 & 1.1437 & 1.4464 & 16.418 & 323.807 \\
\hline 35 & 1.4676 & 2.5196 & 2.3341 & 0.000 & 0.000 & 35 & 0.5508 & 1.3180 & 1.5096 & 0.000 & 0.000 \\
\hline 36 & 2.3642 & 3.2224 & 2.8975 & 0.000 & 0.000 & 36 & 1.3153 & 2.3768 & 2.2226 & 0.000 & 0.000 \\
\hline 37 & 0.7649 & 1.6255 & 2.2634 & 0.000 & 0.000 & 37 & 1.1691 & 1.9997 & 1.9179 & 0.000 & 0.025 \\
\hline 38 & 6.9190 & 7.5011 & 7.6202 & 0.000 & 0.000 & 38 & 0.6325 & 1.4049 & 1.4912 & 0.000 & 0.000 \\
\hline 39 & 0.7003 & 1.6669 & 1.5692 & 0.000 & 0.000 & 39 & 6.3694 & 6.9348 & 7.1142 & 0.000 & 0.000 \\
\hline 40 & 0.6376 & 1.7894 & 1.7345 & 0.000 & 0.000 & 40 & 0.8068 & $\begin{array}{l}1.7517 \\
1.750\end{array}$ & 1.8853 & 0.000 & 0.000 \\
\hline 41 & 0.4881 & 1.5140 & 1.4145 & 0.000 & 0.000 & 41 & 0.6713 & 1.7760 & 1.7862 & 0.000 & 0.000 \\
\hline 42 & 0.1121 & 0.7600 & 0.9913 & 0.000 & 0.000 & 42 & 0.6771 & 1.5720 & 1.6655 & 0.000 & 0.000 \\
\hline 43 & 0.0000 & 0.1470 & 1.0476 & 0.000 & 0.000 & 43 & 0.1498 & 0.8387 & 0.9971 & 0.000 & 0.000 \\
\hline 44 & 1.9433 & 2.9003 & 2.8520 & 0.000 & 0.000 & 44 & 0.0000 & 0.1417 & 1.0702 & 0.000 & 0.000 \\
\hline 45 & 0.0000 & 0.0000 & 1.2354 & 0.000 & 2.869 & 45 & 0.5598 & 1.2920 & 1.7453 & 0.000 & 0.000 \\
\hline & & & & & & 46 & 0.0000 & 0.0000 & 0.0000 & 0.000 & 0.000 \\
\hline Total & & & & 1611.245 & 1650.375 & & & & & 1651.52 & 1510. \\
\hline
\end{tabular}

Notes: Direct capital coefficients $(2,8)$ and total capital requirements $(3,4,9,10)$ are in millions of USD per millions of USD of final demand. Total capital coefficients in $(3,9)$ are the result of multiplication of the US direct capital coefficients by the US Leontief inverse, and those in $(4,10)$ are the result of the multiplication of the US direct capital requirements by China's Leontief inverse for corresponding years. Direct and indirect capital requirements (millions of USD) per millions of USD of exports $(5,11)$ are derived by multiplication of total capital requirements $(3,9)$ by corresponding increase in exports. Similarly total capital requirements per millions of imports $(6,12)$ are the result of multiplication of total capital coefficients $(4,10)$ by corresponding increase in imports. Total increase in exports and imports is one billions USD. 


\section{Table A1. Industry Classification after Aggregation using the US and China's 1997 Input-Output Tables}

Industry Description

\begin{tabular}{|c|c|}
\hline 1 & Crop Production \\
\hline 2 & Animal Production \\
\hline 3 & Forestry and Logging \\
\hline 4 & Fishing, Hunting and Other \\
\hline & Agricutural Products \\
\hline 5 & Crude Petroleum and Natural Gas \\
\hline 6 & Coal \\
\hline 7 & Metals and Non-metallic Mining \\
\hline 8 & Electricity \\
\hline 9 & Other Utilities \\
\hline 10 & Construction \\
\hline 11 & Food Manufacturing \\
\hline 12 & Beverage Manufacturing \\
\hline 13 & Tobacco Products \\
\hline 14 & Textiles and Textile Product Mills \\
\hline 15 & Apparel and Leather Manufacturing \\
\hline 16 & Wood and Wood Products \\
\hline 17 & Paper, Printing and Paper Products \\
\hline 18 & Petroleum and Coal Products Manufacturing \\
\hline 19 & Basic Chemical Products \\
\hline 20 & Plastic, Rubber and Fibers Products \\
\hline 21 & Firtilizers and Pesticides \\
\hline 22 & Medical and Pharmaceutical Products \\
\hline 23 & Other Chemicals \\
\hline 24 & $\begin{array}{l}\text { Cement and Other Non-metallic Mineral } \\
\text { Products }\end{array}$ \\
\hline 25 & Iron and Steel \\
\hline 26 & Nonferrous and Other Ferrous Metals \\
\hline 27 & Metal Products \\
\hline 28 & Boiler, Engines, Tank, Turbine and Container \\
\hline 29 & Metalworking Machinery \\
\hline 30 & $\begin{array}{l}\text { Agricultural and Other Non-electrical } \\
\text { Machinery }\end{array}$ \\
\hline 31 & Electronic and Communication Equipment \\
\hline 32 & Electrical Machinery \\
\hline 33 & Aircraft and Other Transport Equipment \\
\hline 34 & Other Manufacturing \\
\hline 35 & Wholesale and Retail Trade \\
\hline 36 & Air and Other Transport Services \\
\hline 37 & Communication \\
\hline 38 & Finance and Insurance \\
\hline 39 & Real estate and Resident Services \\
\hline 40 & Education, Health and Social Services \\
\hline 41 & Accommodation and Food Services \\
\hline 42 & Arts, Entertainment and Recreation \\
\hline 43 & R\&D, Professional and Technical Services \\
\hline 44 & Public Administration \\
\hline 45 & Other Services \\
\hline 46 & Scrap, used and secondhand goods \\
\hline
\end{tabular}

Industry numbers from the US 1997

Benchmark Input-Output Accounts

1110

1120

1140,1150

2110

2121

$2122,2123,2130$

2211

2212,2213

2301, 2302, 2303

3110

3121

3122

3130,3140

3150,3160

3210

$3221,3222,3230$

3240

3251

3252,3260

3253

3254

$3255,3256,3259$

3270

331A

$331 \mathrm{~B}, 3315,3321$

$3322,3323,332 \mathrm{~A}, 332 \mathrm{~B}$

3324, 3336

3335

3331, 3332 ,

$3333,3334,3339$

$3341,334 \mathrm{~A}$

$3344,3345,3346$

3351, 3352, 3353, 3359

3361, 336A, 3364, 336B

3370, 3391, 3399

4200, 4A00

4810, 4820, 4830, 4840, 4850, 4860, 48A0, 4920, 4930

5111, 5112, 5120, 5131,

5132, 5133, 5141, 5142

52A0, 5230, 5240, 5250

5310, S008, 5321,

532A, 5324, 5330

$6100,6210,6220,6230,6240$

7210,7220

$71 \mathrm{~A} 0,7130$

5411, 5412, 5413, 5414,

5415, 5416, 5417, 5418, 5419 S001, S002, S005

5500, 5613, 5615, 561A, 5620, 8111,

811A, 8120, 813A, 813B, 8140, S007
Industry numbers from the China's 1997 Input-Output Table

\author{
001 \\ 003 \\ 002,013 \\ 004, 005 \\ 007,008 \\ 006 \\ 009, 010, 011, 012 \\ 086 \\ 087, 088, 089 \\ 090 \\ $014,015,016,017,018$ \\ 019,020 \\ 021 \\ 022, 023, 024, 025, 026, 027 \\ 028,029 \\ 030,031 \\ 032,033 \\ 036, 037 \\ 041 \\ 045, 046, 047 \\ 039,040 \\ 044 \\ $038,042,043$ \\ 048, 049, 050, \\ $051,052,053,054$ \\ 055, 056, 057, 058 \\ 059,060 \\ 061 \\ 062 \\ 063 \\ 064, 065, 066
}

076, 077, 078, 079

073, 074, 075

067, 068, 069,

$070,071,072$

080, 081, 082, 083,

$084,034,035$

100

091, 092, 093, 094, 095,096,

097, 102, 103, 104, 105

098, 099

106,107

108,110

$109,114,115,117,118$

101,111

$113,116,119$

$120,121,122$

124

112,123

085 
Table A2. Industry Classification after Aggregation using the US and China's 1992 Input-Output Tables

\begin{tabular}{|c|c|c|c|}
\hline & Industry Description & $\begin{array}{l}\text { Industry numbers from the } \\
\text { US } 1992 \text { Benchmark Input } \\
\text { Output Accounts }\end{array}$ & $\begin{array}{l}\text { Industry numbers from the } \\
\text { China's } 1992 \text { Input-Output Table }\end{array}$ \\
\hline 1 & Crop production & 02 & 1,2 \\
\hline 2 & Animal production & 01 & 4 \\
\hline 3 & Forestry and logging & 03 & 3,15 \\
\hline 4 & $\begin{array}{l}\text { Fishing, Hunting and Other } \\
\text { Agricutural Products }\end{array}$ & 04 & 5,6 \\
\hline 5 & Crude Petroleum and Natural Gas & 08 & 9,10 \\
\hline 6 & Coal & 07 & 7,8 \\
\hline 7 & Metals and Non-metallic Mining & $05+06,09+10$ & $11,12,13,14$ \\
\hline 8 & Electricity & $68 \mathrm{~A}$ & 40 \\
\hline 9 & Other Utilities & $68 \mathrm{~B}, 68 \mathrm{C}$ & 16 , \\
\hline 10 & Construction & 11,12 & 91 \\
\hline 11 & Food and Beverage Manufacturing & 14 & $\begin{array}{c}17,18,19,20 \\
21,22,23,24,26\end{array}$ \\
\hline 12 & Tobacco Products & 15 & 25 \\
\hline 13 & Textiles and Textile Product Mills & $16,17,19$ & $27,28,29,30,31,32$ \\
\hline 14 & Apparel and Leather Manufacturing & $18,33,34$ & 33,34 \\
\hline 15 & Wood and Wood Products & $20+21,22+23$ & 35,36 \\
\hline 16 & Paper, Printing and Paper Products & $24,25,26 \mathrm{~A}, 26 \mathrm{~B}$ & 37,38 \\
\hline 17 & Petroleum and Coal Products Manufacturing & 31 & $41,42,43$ \\
\hline 18 & Basic Chemical Products & $27 \mathrm{~A}$ & 44 \\
\hline 19 & Plastic, Rubber and Fibers Products & 28,32 & $52,53,54,55,56$ \\
\hline 20 & Firtilizers and Pesticides & $27 \mathrm{~B}$ & 45,46 \\
\hline 21 & Medical and Pharmaceutical Products & $29 \mathrm{~A}$ & 51 \\
\hline 22 & Other Chemicals & $29 \mathrm{~B}, 30$ & $47,48,49,50$ \\
\hline 23 & Cement and Other Non-metallic Mineral Products & 35,36 & $57,58,59,60,61,62,63$ \\
\hline 24 & Iron and Steel & 37 & 64 \\
\hline 25 & Nonferrous and Other Ferrous Metals & 38 & 65 \\
\hline 26 & Metal Products & $13,41,42$ & 66,67 \\
\hline 27 & Boiler, Engines, Tank, Turbine and Container & 39,43 & 68 \\
\hline 28 & Metalworking Machinery & 47 & 69 \\
\hline 29 & Agricultural and Other Non-electrical Machinery & $\begin{array}{c}40,44+45,46 \\
48,49,50,52\end{array}$ & $70,71,72,73,74$ \\
\hline 30 & Electronic and Communication Equipment & $51,56,57$ & $83,84,85$ \\
\hline 31 & Electrical Machinery & $53,54,55,58$ & $80,81,82$ \\
\hline 32 & Aircraft and Other Transport Equipment & $59 \mathrm{~A}, 59 \mathrm{~B}, 60,61$ & $75,76,77,78,79$ \\
\hline 33 & Other Manufacturing & $62,63,64$ & $39,86,87,88,89$ \\
\hline 34 & Wholesale and Retail Trade & $69 \mathrm{~A}, 69 \mathrm{~B}$ & 99,100 \\
\hline 35 & Air and Other Transport Services & $65 \mathrm{~A}, 65 \mathrm{~B}, 65 \mathrm{C}, 65 \mathrm{D}, 65 \mathrm{E}$ & $\begin{array}{l}92,93,94,95,96 \\
102,103,104,105\end{array}$ \\
\hline 36 & Communication & 66,67 & 97 \\
\hline 37 & Finance and Insurance & $70 \mathrm{~A}, 70 \mathrm{~B}$ & 116,117 \\
\hline 38 & Real estate and Resident Services & $71 \mathrm{~A}, 71 \mathrm{~B}$ & 106,107 \\
\hline 39 & Education, Health and Social Services & 77A, 77B & $108,109,111,112$ \\
\hline 40 & Accommodation and Food Services & $72 \mathrm{~A}, 74$ & 101 \\
\hline 41 & Arts, Entertainment and Recreation & 76 & 110,113 \\
\hline 42 & R\&D, Professional and Technical Services & 73A, 73B,73C, 73D & 114,115 \\
\hline 43 & Public Administration & $78,79,82$ & 118 \\
\hline 44 & Other Services & $72 \mathrm{~B}, 75,84,85$ & 98 \\
\hline 45 & Scrap, used and secondhand goods & 81 & 90 \\
\hline
\end{tabular}


Table A3. The US emissions from one billions of USD of extra exports and imports, 1992

\begin{tabular}{|c|c|c|c|c|c|c|c|c|c|c|c|c|c|c|c|c|c|c|c|}
\hline \multirow{3}{*}{$\begin{array}{l}\text { Com- } \\
\text { modity } \\
\text { (1) }\end{array}$} & \multicolumn{4}{|c|}{ Trade of the US } & \multicolumn{5}{|c|}{$\mathrm{CO}_{2}$ emissions from the US trade } & \multicolumn{5}{|c|}{$\mathrm{SO}_{2}$ emissions from the US trade } & \multicolumn{5}{|c|}{$\mathrm{NO}_{\mathrm{x}}$ emissions from the US trade } \\
\hline & \multicolumn{2}{|c|}{ with the ROW } & \multicolumn{2}{|c|}{ with China } & \multirow[b]{2}{*}{ Mult. } & \multicolumn{2}{|c|}{ with the ROW } & \multicolumn{2}{|c|}{ with China } & \multirow[b]{2}{*}{ Mult. } & \multicolumn{2}{|c|}{ with the ROW } & \multicolumn{2}{|c|}{ with China } & \multirow[b]{2}{*}{ Mult. } & \multicolumn{2}{|c|}{ with the ROW } & with & China \\
\hline & $\begin{array}{l}\text { Export } \\
\text { (2) }\end{array}$ & $\begin{array}{c}\text { Import } \\
\text { (3) }\end{array}$ & $\begin{array}{c}\text { Export } \\
\text { (4) }\end{array}$ & $\begin{array}{c}\text { Import } \\
(5) \\
\end{array}$ & & $\begin{array}{c}\text { EP } \\
(7)= \\
(6) \times(2)\end{array}$ & $\begin{array}{c}\text { IP } \\
(8)= \\
(6) \times(3)\end{array}$ & $\begin{array}{c}\text { EP } \\
(9)= \\
(6) \times(4)\end{array}$ & $\begin{array}{c}\text { IP } \\
(10)= \\
(6) \times(5)\end{array}$ & & $\begin{array}{c}\mathrm{EP} \\
(12)= \\
(11) \times(2)\end{array}$ & $\begin{array}{c}\text { IP } \\
(13)= \\
(11) \times(3)\end{array}$ & $\begin{array}{c}\text { EP } \\
(14)= \\
(11) \times(4)\end{array}$ & $\begin{array}{c}\mathrm{IP} \\
(15)= \\
(11) \times(5)\end{array}$ & & $\begin{array}{c}\text { EP } \\
(17)= \\
(16) \times(2)\end{array}$ & $\begin{array}{c}\text { IP } \\
(18)= \\
(16) \times(3)\end{array}$ & $\begin{array}{c}\text { EP } \\
(19)= \\
(16) \times(4)\end{array}$ & $\begin{array}{c}\text { IP } \\
(20)= \\
(16) \times(5)\end{array}$ \\
\hline 1 & 55.39 & 14.92 & 67.29 & 2.58 & 0.78 & 43.25 & 11.65 & 52.54 & 2.01 & 7.72 & 427.69 & 115.18 & 519.53 & 19.90 & 3.02 & 167.42 & 45.09 & 203.37 & 7.79 \\
\hline 2 & 2.15 & 3.75 & 1.48 & 1.18 & 0.68 & 1.47 & 2.56 & 1.02 & 0.81 & 6.12 & 13.19 & 22.95 & 9.09 & 7.23 & 5.02 & 10.81 & 18.80 & 7.45 & 5.92 \\
\hline 3 & 5.64 & 1.92 & 17.59 & 0.53 & 0.74 & 4.20 & 1.43 & 13.09 & 0.39 & 7.55 & 42.57 & 14.48 & 132.83 & 3.99 & 2.18 & 12.27 & 4.17 & 38.28 & 1.15 \\
\hline 4 & 7.36 & 9.30 & 2.87 & 16.60 & 0.43 & 3.14 & 3.96 & 1.23 & 7.08 & 4.14 & 30.46 & 38.49 & 11.90 & 68.72 & 1.93 & 14.18 & 17.92 & 5.54 & 31.99 \\
\hline 5 & 1.72 & 84.23 & 0.01 & 16.60 & 5.60 & 9.64 & 471.32 & 0.05 & 92.87 & 58.65 & 101.06 & 4939.72 & 0.53 & 973.38 & 9.45 & 16.28 & 795.55 & 0.09 & 156.76 \\
\hline 6 & 9.86 & 0.25 & 0.66 & 0.00 & 5.51 & 54.30 & 1.38 & 3.64 & 0.01 & 20.45 & 201.72 & 5.11 & 13.53 & 0.03 & 146.51 & 1444.92 & 36.60 & 96.94 & 0.18 \\
\hline 7 & 5.43 & 3.99 & 4.26 & 1.79 & 1.33 & 7.21 & 5.30 & 5.66 & 2.38 & 10.57 & 57.39 & 42.17 & 45.06 & 18.95 & 14.55 & 79.04 & 58.08 & 62.06 & 26.10 \\
\hline 8 & 0.00 & 0.00 & 0.00 & 0.00 & 4.46 & 0.00 & 0.00 & 0.00 & 0.00 & 17.54 & 0.00 & 0.00 & 0.00 & 0.00 & 115.17 & 0.00 & 0.00 & 0.00 & 0.00 \\
\hline 9 & 0.00 & 0.00 & 0.00 & 0.00 & 10.43 & 0.00 & 0.00 & 0.00 & 0.00 & 110.37 & 0.00 & 0.00 & 0.00 & 0.00 & 13.75 & 0.00 & 0.00 & 0.00 & 0.00 \\
\hline 10 & 0.00 & 0.00 & 0.00 & 0.00 & 0.48 & 0.00 & 0.00 & 0.00 & 0.00 & 4.42 & 0.00 & 0.00 & 0.00 & 0.00 & 3.00 & 0.00 & 0.00 & 0.00 & 0.00 \\
\hline 11 & 44.95 & 32.42 & 4.91 & 8.47 & 0.55 & 24.66 & 17.79 & 2.69 & 4.65 & 4.77 & 214.62 & 154.80 & 23.43 & 40.45 & 4.52 & 203.12 & 146.50 & 22.18 & 38.29 \\
\hline 12 & 10.51 & 0.71 & 1.48 & 0.26 & 0.20 & 2.06 & 0.14 & 0.29 & 0.05 & 1.61 & 16.95 & 1.14 & 2.38 & 0.42 & 1.95 & 20.50 & 1.38 & 2.88 & 0.51 \\
\hline 13 & 11.68 & 15.04 & 7.27 & 43.24 & 0.60 & 6.97 & 8.98 & 4.34 & 25.82 & 4.89 & 57.07 & 73.49 & 35.53 & 211.30 & 6.06 & 70.73 & 91.08 & 44.04 & 261.90 \\
\hline 14 & 15.37 & 86.19 & 2.08 & 381.87 & 0.39 & 6.06 & 33.99 & 0.82 & 150.61 & 3.27 & 50.24 & 281.71 & 6.81 & 1248.10 & 3.85 & 59.22 & 332.09 & 8.03 & 1471.27 \\
\hline 15 & 10.63 & 12.78 & 1.06 & 9.08 & 0.47 & 5.02 & 6.03 & 0.50 & 4.29 & 4.07 & 43.28 & 51.99 & 4.31 & 36.94 & 4.04 & 42.98 & 51.63 & 4.28 & 36.69 \\
\hline 16 & 32.40 & 24.39 & 21.60 & 8.88 & 0.53 & 17.19 & 12.94 & 11.46 & 4.71 & 4.28 & 138.72 & 104.41 & 92.47 & 38.02 & 5.61 & 181.75 & 136.79 & 121.15 & 49.81 \\
\hline 17 & 13.92 & 21.29 & 26.56 & 1.70 & 15.47 & 215.31 & 329.36 & 410.86 & 26.26 & 163.49 & 2275.29 & 3480.49 & 4341.79 & 277.51 & 21.17 & 294.63 & 450.70 & 562.23 & 35.94 \\
\hline 18 & 40.53 & 23.17 & 42.57 & 9.83 & 2.25 & 91.34 & 52.22 & 95.94 & 22.15 & 21.87 & 886.24 & 506.66 & 930.85 & 214.94 & 10.26 & 415.75 & 237.69 & 436.68 & 100.84 \\
\hline 19 & 38.87 & 22.52 & 37.34 & 25.98 & 0.84 & 32.58 & 18.87 & 31.29 & 21.77 & 7.43 & 288.83 & 167.33 & 277.43 & 193.02 & 6.40 & 248.83 & 144.15 & 239.00 & 166.29 \\
\hline 20 & 8.43 & 3.02 & 87.04 & 0.12 & 2.13 & 17.93 & 6.42 & 185.17 & 0.25 & 20.81 & 175.41 & 62.81 & 1811.56 & 2.44 & 9.06 & 76.33 & 27.33 & 788.35 & 1.06 \\
\hline 21 & 16.05 & 11.85 & 4.32 & 3.63 & 0.30 & 4.79 & 3.54 & 1.29 & 1.08 & 2.56 & 41.04 & 30.31 & 11.04 & 9.27 & 2.61 & 41.84 & 30.90 & 11.25 & 9.45 \\
\hline 22 & $\begin{array}{l}18.34 \\
\end{array}$ & 9.83 & 5.29 & 4.48 & 0.70 & 12.78 & 6.85 & 3.69 & 3.13 & 6.56 & 120.32 & 64.52 & $\begin{array}{l}11.04 \\
34.69\end{array}$ & 29.42 & 3.92 & 71.79 & 38.49 & $\begin{array}{l}20.70 \\
20\end{array}$ & 17.56 \\
\hline 23 & 9.10 & 11.81 & 5.23 & 15.28 & 1.15 & 10.44 & 13.56 & 6.01 & 17.54 & 8.48 & 77.18 & 100.19 & 44.39 & 129.59 & 15.01 & 136.53 & $\begin{array}{l}177.24 \\
\end{array}$ & 78.53 & 229.24 \\
\hline 24 & $\begin{array}{l}.10 \\
7.95\end{array}$ & $\begin{array}{l}11.01 \\
18.67\end{array}$ & $\begin{array}{l}9.25 \\
9.51\end{array}$ & $\begin{array}{l}1.98 \\
1.99\end{array}$ & $\begin{array}{l}1.133 \\
1.73\end{array}$ & $\begin{array}{l}10.44 \\
13.77\end{array}$ & $\begin{array}{l}32.30 \\
32.34\end{array}$ & $\begin{array}{l}.0 .01 \\
16.48\end{array}$ & 3.45 & & 77.37 & 181.80 & 92.60 & 19.37 & $\begin{array}{l}1.01 \\
33.93\end{array}$ & $\begin{array}{l}269.65 \\
269.5\end{array}$ & 633.56 & 322.73 & 67.52 \\
\hline 25 & 23.30 & 22 & 30 & 4. & 0.77 & 1 & 1 & 20.69 & 3.41 & 5 & 139.68 & 13 & 160.64 & 26 & 9.03 & 21 & 21 & 241.90 & 39.91 \\
\hline 26 & 2 & & & 27.78 & 0.56 & 13.94 & 12. & 5.00 & 15.46 & & 105.12 & 9 & 9 & 116.61 & 6.96 & 1 & 10 & 62.53 & 193.48 \\
\hline 27 & 18.46 & 10.04 & 15.47 & 1.96 & 0.61 & 11.25 & 6.12 & 9. & 1.19 & 4.39 & 81.06 & 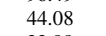 & 67.94 & 8. & 8.37 & 154 & 84 & 129.51 & 16.39 \\
\hline 28 & 7.55 & 7.33 & 15.68 & 1.31 & 0.42 & 3.16 & 3.07 & 6.56 & 0.55 & 3.14 & 23.66 & 22.99 & 49.16 & 4. & 5.3 & 40. & 38.97 & 83.35 & 6.97 \\
\hline 29 & 100.41 & 55.06 & 95.84 & 19.80 & 0.47 & 47.49 & 26.04 & 45.33 & 9.36 & 3.49 & 350.01 & 191.93 & 334.09 & 69.01 & 6.2 & 624.33 & 342.35 & 595.93 & 123.09 \\
\hline 30 & 183.13 & 177.08 & 125.83 & 106.01 & 0.23 & 41.75 & 40.37 & 28.69 & 24.17 & 1.79 & 328.31 & 317.46 & 225.58 & 190.05 & 2. & 473 & 457.58 & 325.15 & 273.93 \\
\hline 31 & 32.52 & 32.47 & 14.91 & 66.98 & 0.44 & 14.19 & 14.1 & 6.50 & 29.22 & 3.49 & 113 & 113 & 52.07 & 234.00 & 4.71 & 153 & 152.93 & 70.20 & 315.46 \\
\hline 32 & 192.53 & 191.58 & 316.57 & 8.90 & 0.40 & 77.13 & 76.75 & 126.82 & 3.56 & 3.19 & 614.04 & 611.01 & 1009.63 & 28.37 & 4.40 & 846.19 & 842.03 & 1391.35 & 39.10 \\
\hline 33 & 37.10 & 62.25 & 10.57 & 206.45 & 0.29 & 10.76 & 18.05 & 3.06 & 59.85 & 2.30 & 85.39 & 143.28 & 24.33 & 475.17 & 3.20 & 118.79 & 199.33 & 33.85 & 661.03 \\
\hline 34 & 0.00 & 0.00 & 0.00 & 0.00 & 0.27 & 0.00 & 0.00 & 0.00 & 0.00 & 2.25 & 0.00 & 0.00 & 0.00 & 0.00 & 2.53 & 0.00 & 0.00 & 0.00 & 0.00 \\
\hline 35 & 0.00 & 0.00 & 0.00 & 0.00 & 1.13 & 0.00 & 0.00 & 0.00 & 0.00 & 11.53 & 0.00 & 0.00 & 0.00 & 0.00 & 2.86 & 0.00 & 0.00 & 0.00 & 0.00 \\
\hline 36 & 0.00 & 0.00 & 0.00 & 0.00 & 0.15 & 0.00 & 0.00 & 0.00 & 0.00 & 1.23 & 0.00 & 0.00 & 0.00 & 0.00 & 1.36 & 0.00 & 0.00 & 0.00 & 0.00 \\
\hline 37 & 0.00 & 0.00 & 0.00 & 0.00 & 0.15 & 0.00 & 0.00 & 0.00 & 0.00 & 1.29 & 0.00 & 0.00 & 0. & 0.00 & 1.19 & 0.00 & 0.00 & 0.00 & 0.00 \\
\hline 38 & 0.00 & 0.00 & 0.00 & 0.00 & 0.14 & 0.00 & 0.00 & 0.00 & 0.00 & 1.17 & 0.00 & 0.00 & 0.8 & 0. & 1.20 & 0.0 & 0.00 & 0.00 & 0.00 \\
\hline 39 & 0.00 & 0.00 & 0.00 & 0.00 & 0.24 & 0.00 & 0.00 & 0.00 & 0.00 & 2.08 & 0.00 & 0.0 & 0.8 & 0. & 1.95 & 0.0 & 0.00 & 0.00 & 0.00 \\
\hline 40 & 0.00 & 0.00 & 0.00 & 0.0 & 0.45 & 0.00 & 0.00 & 0.00 & 0.00 & 3.71 & 0.00 & 0.0 & 0. & 0. & 4.53 & 0.0 & 0.00 & 0.00 & 0.00 \\
\hline 41 & 0.00 & 0.00 & 0.00 & 0.0 & 0.26 & 0.00 & 0.00 & 0.00 & 0.00 & 2.12 & 0.00 & 0.0 & 0. & 0 & 2.81 & 0.0 & 0.00 & 0.00 & 0.00 \\
\hline 42 & 0.00 & 0.00 & 0.00 & 0.0 & 0.17 & 0.00 & 0.0 & 0.00 & 0.00 & 1.48 & 0.00 & 0.0 & 0. & 0. & 1.38 & 0.00 & 0.00 & 0.00 & 0.00 \\
\hline 43 & 0.00 & 0.00 & 0.00 & 0.0 & 0.28 & 0.00 & 0.00 & 0.00 & 0. & 2.06 & 0.00 & 0.0 & 0. & 0. & $\begin{array}{l}3.60 \\
3.63\end{array}$ & 0.00 & 0.00 & 0.00 & 0.00 \\
\hline 44 & 0.00 & 0.00 & 0.0 & 0.8 & 0.38 & 0.00 & 0.0 & 0.0 & 0. & 3.40 & 0. & 0. & 0. & 0.00 & 2.62 & 0.00 & 0.00 & 0.00 & 0.00 \\
\hline 45 & 13.68 & 6.32 & 18.94 & 2.32 & 0.00 & 0.00 & 0.00 & 0.00 & 0.00 & 0.00 & 0.00 & 0.00 & 0.00 & 0.00 & 0.00 & 0.00 & 0.00 & 0.00 & 0.00 \\
\hline Total & 1000.00 & 1000.00 & 1000.00 & 1000.00 & & 821.76 & 1255.61 & 1100.13 & 538.08 & & 7177.53 & 12117.37 & 10402.93 & 4695.42 & & 6673.66 & 5959.27 & 6009.54 & 4385.59 \\
\hline
\end{tabular}


Table A4. The China's emissions from one billions of RMB of extra exports and imports, 1992

\begin{tabular}{|c|c|c|c|c|c|c|c|c|c|c|c|c|c|c|c|c|c|c|c|}
\hline \multirow{3}{*}{$\begin{array}{l}\text { Com- } \\
\text { modity } \\
\text { (1) }\end{array}$} & \multicolumn{4}{|c|}{ Trade of China } & \multicolumn{5}{|c|}{$\mathrm{CO}_{2}$ emissions from China's trade } & \multicolumn{5}{|c|}{$\mathrm{SO}_{2}$ emissions from China's trade } & \multicolumn{5}{|c|}{$\mathrm{NO}_{\mathrm{x}}$ emissions from China's trade } \\
\hline & \multicolumn{2}{|c|}{ with the ROW } & \multicolumn{2}{|c|}{ with the US } & \multirow[b]{2}{*}{$\begin{array}{l}\text { Mult. } \\
\text { (6) }\end{array}$} & \multicolumn{2}{|c|}{ with the ROW } & \multicolumn{2}{|c|}{ with the US } & \multirow[b]{2}{*}{ Mult. } & \multicolumn{2}{|c|}{ with the ROW } & \multicolumn{2}{|c|}{ with the US } & \multirow[b]{2}{*}{$\begin{array}{l}\text { Mult. } \\
\text { (16) }\end{array}$} & \multicolumn{2}{|c|}{ with the ROW } & with & e US \\
\hline & $\begin{array}{c}\text { Export } \\
\text { (2) }\end{array}$ & $\begin{array}{c}\text { Import } \\
\text { (3) }\end{array}$ & $\begin{array}{c}\text { Export } \\
\text { (4) }\end{array}$ & $\begin{array}{c}\text { Import } \\
(5)\end{array}$ & & $\begin{array}{c}\text { EP } \\
(7)= \\
(6) \times(2)\end{array}$ & $\begin{array}{c}\text { IP } \\
(8)= \\
(6) \times(3)\end{array}$ & $\begin{array}{c}E P \\
(9)= \\
(6) \times(4)\end{array}$ & $\begin{array}{c}\text { IP } \\
(10)= \\
(6) \times(5)\end{array}$ & & $\begin{array}{c}\mathrm{EP} \\
(12)= \\
(11) \times(2)\end{array}$ & $\begin{array}{c}\text { IP } \\
(13)= \\
(11) \times(3)\end{array}$ & $\begin{array}{c}\mathrm{EP} \\
(14)= \\
(11) \times(4)\end{array}$ & $\begin{array}{c}\mathrm{IP} \\
(15)= \\
(11) \times(5)\end{array}$ & & $\begin{array}{c}\text { EP } \\
(17)= \\
(16) \times(2)\end{array}$ & $\begin{array}{c}\text { IP } \\
(18)= \\
(16) \times(3)\end{array}$ & $\begin{array}{c}\text { EP } \\
(19)= \\
(16) \times(4)\end{array}$ & $\begin{array}{c}\text { IP } \\
(20)= \\
(16) \times(5)\end{array}$ \\
\hline & 31.94 & 23.92 & 2.58 & 67.29 & 0.23 & 7.35 & 5.50 & 0.59 & 15.48 & 1.35 & 42.96 & 32.17 & 3.47 & 90.50 & & 137.71 & 103.12 & 11.11 & 290.13 \\
\hline 2 & 9.58 & 6.32 & 1.18 & 1.48 & 0.17 & 1.66 & 1.10 & 0.21 & 0.26 & 0.92 & 8.77 & 5.78 & 1.08 & 1.36 & 3.62 & 34.71 & 22.89 & 4.28 & 5.38 \\
\hline 3 & 1.43 & 8.45 & 0.53 & $\begin{array}{l}1.48 \\
17.59\end{array}$ & 0.15 & 0.21 & 1.27 & 0.08 & 2.65 & 0.88 & 1.26 & 7.43 & 0.46 & 15.48 & 2.83 & 4.04 & 23.86 & $\begin{array}{l}4.48 \\
1.49\end{array}$ & $\begin{array}{r}3.50 \\
49.69\end{array}$ \\
\hline 4 & 4.30 & 0.86 & 16.60 & 2.87 & 0.21 & 0.90 & 0.18 & 3.46 & 0.60 & 1.35 & 5.83 & 1.17 & 22.48 & 3.89 & 3.41 & 14.69 & 2.95 & 56.66 & 9.81 \\
\hline 5 & 9.36 & 18.35 & 16.60 & 0.01 & 0.45 & 4.24 & 8.31 & 7.52 & 0.00 & 3.01 & 28.13 & 55.17 & 49.89 & 0.03 & 7.18 & 67.22 & 131.81 & 119.21 & 0.07 \\
\hline 6 & 7.93 & 0.46 & 0.00 & 0.66 & 1.05 & 8.29 & 0.48 & 0.00 & 0.69 & 4.36 & 34.61 & 2.01 & 0.01 & 2.89 & 26.04 & 206.51 & 12.00 & 0.03 & 17.23 \\
\hline 7 & 6.46 & 12.65 & 1.79 & 4.26 & 0.74 & 4.78 & 9.36 & 1.33 & 3.16 & 3.72 & 24.06 & 47.08 & 6.67 & 15.87 & 16.11 & 104.15 & 203.79 & 28.89 & 68.71 \\
\hline 8 & 0.05 & 2.99 & 0.00 & 0.00 & 2.95 & 0.16 & 8.84 & 0.00 & 0.00 & 12.64 & 0.69 & 37.86 & 0.00 & 0.00 & 72.42 & 3.98 & 216.86 & 0.00 & 0.00 \\
\hline 9 & 0.00 & 0.00 & 0.00 & 0.00 & 0.87 & 0.00 & 0.00 & 0.00 & 0.00 & 3.91 & 0.00 & 0.00 & 0.00 & 0.00 & 20.77 & 0.00 & 0.00 & 0.00 & 0.00 \\
\hline 10 & 0.00 & 0.00 & 0.00 & 0.00 & 0.56 & 0.00 & 0.00 & 0.00 & 0.00 & 2.91 & 0.00 & 0.00 & 0.00 & 0.00 & 11.74 & 0.00 & 0.00 & 0.00 & 0.00 \\
\hline 11 & 56.33 & 21.63 & 8.47 & 4.91 & 0.35 & 19.58 & 7.52 & 2.95 & 1.71 & 1.81 & 102.09 & 39.20 & 15.35 & 8.89 & 7.33 & 412.96 & $\begin{array}{l}0.00 \\
158.59\end{array}$ & 62.11 & 35.98 \\
\hline 12 & 3.68 & 2.42 & 0.26 & 1.48 & 0.15 & 0.55 & 0.36 & 0.04 & 0.22 & 0.82 & 3.01 & 1.98 & 0.21 & 1.21 & 3.06 & 11.25 & 7.39 & 0.79 & 4.51 \\
\hline 13 & 151.16 & 88.03 & 43.24 & 7.27 & 0.37 & 56.38 & 32.84 & 16.13 & 2.71 & 1.90 & 286.77 & 167.00 & 82.02 & 13.79 & 8.04 & 1215.20 & 707.68 & 347.57 & 58.45 \\
\hline 14 & 172.00 & 23.23 & 381.87 & 2.08 & 0.30 & 51.84 & 7.00 & 115.10 & 0.63 & 1.63 & 281.07 & 37.95 & 624.01 & 3.40 & 6.13 & 1053.56 & 142.27 & 2339.07 & 12.76 \\
\hline 15 & 20.93 & 11.17 & 9.08 & 1.06 & 0.55 & 11.55 & 6.17 & 5.01 & 0.59 & 2.84 & 59.48 & 31.75 & 25.80 & 3.01 & 11.77 & 246.40 & 131.50 & 106.85 & 12.48 \\
\hline 16 & 10.11 & 24.05 & 8.88 & 21.60 & 0.48 & 4.83 & 11.49 & 4.24 & 10.32 & 2.41 & 24.34 & 57.91 & 21.38 & 52.00 & 10.39 & 105.01 & 249.84 & 92.23 & 224.35 \\
\hline 17 & 10.04 & 16.32 & 1.70 & 26.56 & 4.53 & 45.48 & 73.95 & 7.69 & 120.36 & 39.33 & 394.66 & 641.63 & 66.75 & 1044.34 & 37.76 & 378.98 & 616.13 & 64.10 & 1002.83 \\
\hline 18 & 11.81 & 4.11 & 9.83 & 42.57 & 1.11 & 13.10 & 4.56 & 10.90 & 47.22 & 5.98 & 70.58 & 24.55 & 58.73 & 254.35 & 22.69 & 268.03 & 93.21 & 223.02 & 965.85 \\
\hline $\begin{array}{l}19 \\
19\end{array}$ & 37.95 & 31.04 & 25.98 & 37.34 & 0.47 & 17.90 & 14.64 & 12.26 & 17.62 & 2.91 & 110.60 & 90.47 & 75.72 & 108.84 & 8.27 & 313.95 & 256.81 & 214.95 & 308.94 \\
\hline 20 & 1.15 & 34.67 & 0.12 & 87.04 & 1.46 & 1.68 & 50.48 & 0.17 & 126.75 & 8.09 & 9.33 & 280.32 & 0.95 & 703.84 & 28.88 & 33.33 & 1001.34 & 3.38 & 2514.25 \\
\hline 21 & 8.17 & 3.47 & 3.63 & 4.32 & 0.43 & 3.47 & 1.48 & 1.54 & 1.83 & 2.22 & 18.15 & 7.72 & 8.06 & 9.59 & 8.94 & 73.03 & 31.06 & 32.43 & 38.59 \\
\hline $\begin{array}{l}21 \\
22\end{array}$ & $\begin{array}{l}0.17 \\
29.78\end{array}$ & $\begin{array}{l}.3 .41 \\
78.47\end{array}$ & $\begin{array}{l}4.03 \\
4.48\end{array}$ & $\begin{array}{l}4.52 \\
5.29\end{array}$ & $\begin{array}{l}0.45 \\
0.83\end{array}$ & 24.67 & 65.00 & $\begin{array}{l}3.54 \\
3.71\end{array}$ & $\begin{array}{l}1.03 \\
4.38\end{array}$ & 5.72 & $\begin{array}{l}1.13 \\
170.37\end{array}$ & 448.96 & 25.65 & 30.25 & 12.30 & 366.38 & 965.48 & 55.17 & 65.05 \\
\hline 23 & 27.73 & 8.37 & $\begin{array}{l}15.40 \\
15.28\end{array}$ & 5.23 & $\begin{array}{l}0.03 \\
1.08\end{array}$ & 29.87 & 9.02 & 16.46 & 5.64 & 5.09 & 141.23 & 42.63 & 77.82 & 26.66 & 24.65 & 683.33 & 206.26 & 376.50 & 128.98 \\
\hline 24 & $\begin{array}{l}14.80 \\
1.75\end{array}$ & $\begin{array}{l}.3 .31 \\
49.77\end{array}$ & $\begin{array}{l}15.28 \\
1.99\end{array}$ & $\begin{array}{l}5.25 \\
9.51\end{array}$ & $\begin{array}{l}1.08 \\
1.22\end{array}$ & $\begin{array}{l}29.81 \\
18.06\end{array}$ & $\begin{array}{l}.902 \\
60.76\end{array}$ & $\begin{array}{l}10.40 \\
2.43\end{array}$ & $\begin{array}{r}.04 \\
11.61\end{array}$ & $\begin{array}{l}5.09 \\
5.64\end{array}$ & 83.40 & $\begin{array}{l}4.03 \\
280.51\end{array}$ & $\begin{array}{l}11.22 \\
11.21\end{array}$ & $\begin{array}{l}20.00 \\
53.60\end{array}$ & $\begin{array}{l}28.03 \\
28.43\end{array}$ & $\begin{array}{l}480.67 \\
420.57\end{array}$ & $\begin{array}{l}200.20 \\
1414.98\end{array}$ & 56.57 & $\begin{array}{l}128.98 \\
270.39\end{array}$ \\
\hline 25 & $\begin{array}{l}14.00 \\
11.89\end{array}$ & 31.25 & 4.42 & $\begin{array}{l}.31 \\
26.80\end{array}$ & $\begin{array}{l}1.22 \\
0.73\end{array}$ & $\begin{array}{l}80.00 \\
8.69\end{array}$ & 22.85 & 3.23 & $\begin{array}{l}11.01 \\
19.59\end{array}$ & $\begin{array}{l}3.04 \\
3.89\end{array}$ & $\begin{array}{l}0.40 \\
46.28\end{array}$ & 121.68 & $\begin{array}{r}11.21 \\
17.21\end{array}$ & $\begin{array}{l}104.00 \\
104.33\end{array}$ & $\begin{array}{l}20.43 \\
15.12\end{array}$ & 179.69 & $\begin{array}{l}1414.90 \\
472.45\end{array}$ & 66.83 & 405.11 \\
\hline 26 & $\begin{array}{l}11.89 \\
28.81\end{array}$ & $\begin{array}{l}51.25 \\
10.02\end{array}$ & $\begin{array}{l}.4 .42 \\
27.78\end{array}$ & $\begin{array}{l}20.80 \\
8.98\end{array}$ & $\begin{array}{l}0.13 \\
0.67\end{array}$ & $\begin{array}{l}.09 \\
19.32\end{array}$ & $\begin{array}{l}22.85 \\
6.72\end{array}$ & $\begin{array}{l}3.23 \\
18.64\end{array}$ & $\begin{array}{l}19.39 \\
6.02\end{array}$ & $\begin{array}{l}3.89 \\
3.32\end{array}$ & $\begin{array}{l}46.28 \\
95.66\end{array}$ & 33.27 & $\begin{array}{l}11.21 \\
92.25\end{array}$ & $\begin{array}{l}204.33 \\
29.81\end{array}$ & $\begin{array}{l}13.12 \\
14.80\end{array}$ & $\begin{array}{r}179.69 \\
426.28\end{array}$ & $\begin{array}{l}712.45 \\
148.27\end{array}$ & $\begin{array}{r}\text { 6. } \\
411.03 \\
\end{array}$ & $\begin{array}{l}4052.11 \\
13287\end{array}$ \\
\hline $\begin{array}{l}26 \\
27\end{array}$ & $\begin{array}{l}28.81 \\
2.82\end{array}$ & $\begin{array}{l}10.02 \\
12.80\end{array}$ & 1.96 & $\begin{array}{l}8.98 \\
15.47\end{array}$ & $\begin{array}{l}0.51 \\
0.51\end{array}$ & $\begin{array}{l}19.32 \\
1.43\end{array}$ & $\begin{array}{l}\text {. } \\
6.51\end{array}$ & $\begin{array}{l}18.04 \\
1.00\end{array}$ & $\begin{array}{l}\text {.0. } \\
7.87\end{array}$ & $\begin{array}{l}3.32 \\
2.60\end{array}$ & $\begin{array}{l}95.60 \\
7.32\end{array}$ & $\begin{array}{l}33.27 \\
33.24\end{array}$ & $\begin{array}{l}22.25 \\
5.08\end{array}$ & $\begin{array}{l}2.81 \\
40.17\end{array}$ & $\begin{array}{l}14.80 \\
10.93\end{array}$ & $\begin{array}{l}\begin{array}{r}420.28 \\
30.84\end{array} \\
3\end{array}$ & $\begin{array}{l}148.27 \\
140.00\end{array}$ & $\begin{array}{l}111.09 \\
21.42\end{array}$ & $\begin{array}{l}132.87 \\
169.20\end{array}$ \\
\hline 28 & $\begin{array}{l}0.82 \\
0.60\end{array}$ & 12.11 & $\begin{array}{l}1.96 \\
1.31\end{array}$ & $\begin{array}{l}15.47 \\
15.68\end{array}$ & $\begin{array}{l}0.51 \\
0.44\end{array}$ & $\begin{array}{l}1.43 \\
0.26\end{array}$ & $\begin{array}{l}0.51 \\
5.27\end{array}$ & $\begin{array}{l}1.00 \\
0.57\end{array}$ & $\begin{array}{l}.8 .81 \\
6.83\end{array}$ & $\begin{array}{l}2.00 \\
2.29\end{array}$ & $\begin{array}{l}1.32 \\
1.38\end{array}$ & $\begin{array}{l}37.24 \\
27.73\end{array}$ & $\begin{array}{l}3.08 \\
3.00\end{array}$ & $\begin{array}{l}40.17 \\
35.90\end{array}$ & $\begin{array}{l}10.93 \\
9.11\end{array}$ & $\begin{array}{l}50.84 \\
5.50\end{array}$ & $\begin{array}{l}140.00 \\
110.30\end{array}$ & $\begin{array}{l}2.42 \\
11.93\end{array}$ & $\begin{array}{l}169.20 \\
142.79\end{array}$ \\
\hline 29 & 80.73 & 177.56 & 19.80 & 95.84 & 0.51 & 40.91 & 89.99 & 10.03 & 48.57 & 2.63 & 212.50 & 467.38 & 52.11 & 252.28 & 10.72 & 865.65 & 1903.98 & 212.27 & 1027.73 \\
\hline 30 & 61.00 & 78.30 & 106.01 & 125.83 & 0.31 & 18.94 & 24.30 & 32.90 & 39.06 & 1.74 & 105.96 & $\begin{array}{l}136.00 \\
0\end{array}$ & 184.12 & 218.55 & 6.11 & 372.73 & 478.41 & 647.71 & 768.81 \\
\hline 31 & 44.78 & 43.15 & 66.98 & 14.91 & 0.45 & 20.35 & 19.61 & 30.44 & 6.77 & 2.43 & 108.62 & 104.68 & 162.49 & 36.16 & $\begin{array}{l}0.11 \\
9.38\end{array}$ & 419.86 & 404.62 & 628.09 & 139.77 \\
\hline 32 & 17.16 & 79.37 & 8.90 & 316.57 & 0.39 & 6.66 & 30.80 & 3.45 & 122.83 & 2.08 & 35.71 & 165.20 & 18.52 & 658.87 & 7.97 & $\begin{array}{l}136.00 \\
136.72\end{array}$ & 632.39 & 70.88 & 2522.20 \\
\hline 33 & 61.61 & 21.88 & 206.45 & 10.57 & 0.40 & 24.92 & 8.85 & 83.51 & 4.28 & 2.19 & 134.92 & 47.92 & 452.13 & 23.15 & 8.23 & 507.16 & 180.14 & 1699.55 & 87.02 \\
\hline 34 & 0.00 & 56.65 & 0.00 & 0.00 & 0.37 & 0.00 & 21.20 & 0.00 & 0.00 & 2.28 & 0.00 & 129.43 & 0.00 & 0.00 & 6.66 & 0.00 & 377.53 & 0.00 & 0.00 \\
\hline 35 & 33.70 & 0.00 & 0.00 & 0.00 & 0.80 & 27.10 & 0.00 & 0.00 & 0.00 & 5.82 & 196.02 & 0.00 & 0.00 & 0.00 & 10.98 & 369.90 & 0.00 & 0.00 & 0.00 \\
\hline 36 & 2.18 & 0.00 & 0.00 & 0.00 & 0.23 & 0.50 & 0.00 & 0.00 & 0.00 & 1.25 & 2.72 & 0.00 & 0.00 & 0.00 & 4.65 & 10.14 & 0.00 & 0.00 & 0.00 \\
\hline 37 & 1.79 & 0.00 & 0.00 & 0.00 & 0.29 & 0.53 & 0.00 & 0.00 & 0.00 & 1.60 & 2.87 & 0.00 & 0.00 & 0.00 & 5.94 & 10.67 & 0.00 & 0.00 & 0.00 \\
\hline 38 & 0.62 & 0.00 & 0.00 & 0.00 & 0.46 & 0.28 & 0.00 & 0.00 & 0.00 & 2.66 & 1.66 & 0.00 & 0.00 & 0.00 & 8.53 & 5.31 & 0.00 & 0.00 & 0.00 \\
\hline 39 & 12.34 & 0.00 & 0.00 & 0.00 & 0.36 & 4.43 & 0.00 & 0.00 & 0.00 & 1.84 & 22.77 & 0.00 & 0.00 & 0.00 & 7.66 & 94.53 & 0.00 & 0.00 & 0.00 \\
\hline 40 & 0.00 & 0.00 & 0.00 & 0.00 & 0.28 & 0.00 & 0.00 & 0.00 & 0.00 & 1.62 & 0.00 & 0.00 & 0.00 & 0.00 & 5.42 & 0.00 & 0.00 & 0.00 & 0.00 \\
\hline 41 & 0.48 & 0.00 & 0.00 & 0.00 & 0.30 & 0.14 & 0.00 & 0.00 & 0.00 & 1.59 & 0.76 & 0.00 & 0.00 & 0.00 & 6.37 & 3.03 & 0.00 & 0.00 & 0.00 \\
\hline 42 & 0.57 & 0.04 & 0.00 & 0.00 & 0.32 & 0.18 & 0.01 & 0.00 & 0.00 & 1.81 & 1.03 & 0.07 & 0.00 & 0.00 & 6.25 & 3.55 & 0.24 & 0.00 & 0.00 \\
\hline 43 & 0.00 & 0.00 & 0.00 & 0.00 & $\begin{array}{l}0.52 \\
0.40\end{array}$ & $\begin{array}{l}0.18 \\
0.00\end{array}$ & 0.00 & 0.00 & 0.00 & $\begin{array}{l}1.01 \\
2.30\end{array}$ & 0.00 & 0.00 & 0.00 & 0.00 & $\begin{array}{l}7.69 \\
7.69\end{array}$ & 0.00 & $\begin{array}{l}0.24 \\
0.00\end{array}$ & 0.00 & 0.00 \\
\hline 44 & 12.23 & 0.00 & 0.00 & 0.00 & $\begin{array}{l}0.40 \\
0.21\end{array}$ & 2.54 & 0.00 & 0.00 & 0.00 & 1.19 & 14.51 & 0.00 & 0.00 & 0.00 & 4.00 & 48.97 & 0.00 & 0.00 & 0.00 \\
\hline 45 & $\begin{array}{l}12.25 \\
0.00\end{array}$ & $\begin{array}{l}6.00 \\
6.12\end{array}$ & $\begin{array}{l}.000 \\
2.32\end{array}$ & $\begin{array}{l}0.00 \\
18.94\end{array}$ & $\begin{array}{l}0.71 \\
0.74\end{array}$ & $\begin{array}{l}2.54 \\
0.00\end{array}$ & $\begin{array}{l}.000 \\
4.53\end{array}$ & $\begin{array}{l}.00 \\
1.72\end{array}$ & $\begin{array}{l}0.00 \\
14.00\end{array}$ & $\begin{array}{l}1.19 \\
4.15\end{array}$ & $\begin{array}{l}14.01 \\
0.00\end{array}$ & $\begin{array}{l}0.00 \\
25.44\end{array}$ & $\begin{array}{l}9.00 \\
9.65\end{array}$ & $\begin{array}{l}0.00 \\
78.66\end{array}$ & $\begin{array}{l}4.00 \\
14.49\end{array}$ & $\begin{array}{r}8.971 \\
0.00\end{array}$ & 88.74 & $\begin{array}{l}0.00 \\
33.66\end{array}$ & $\begin{array}{l}0.00 \\
274.42\end{array}$ \\
\hline Total & 1000.00 & 1000.00 & 1000.00 & 1000.00 & & 503.79 & 620.97 & 397.31 & 650.24 & & 2892.10 & 3633.30 & 2174.31 & 3921.70 & & 9645.61 & 11636.88 & 7999.84 & 11754.34 \\
\hline
\end{tabular}


Individual researchers, as well as the on-line and printed versions of the CERGE-EI Working Papers (including their dissemination) were supported from the following institutional grants:

- Center of Advanced Political Economy Research [Centrum pro pokročilá politicko-ekonomická studia], No. LC542, (2005-2009),

- Economic Aspects of EU and EMU Entry [Ekonomické aspekty vstupu do Evropské unie a Evropské měnové unie], No. AVOZ70850503, (2005-2010);

- Economic Impact of European Integration on the Czech Republic [Ekonomické dopady evropské integrace na ČR], No. MSM0021620846, (2005-2011);

Specific research support and/or other grants the researchers/publications benefited from are acknowledged at the beginning of the Paper.

(c) Umed Temurshoev, 2006

All rights reserved. No part of this publication may be reproduced, stored in a retrieval system or transmitted in any form or by any means, electronic, mechanical or photocopying, recording, or otherwise without the prior permission of the publisher.

Published by

Charles University in Prague, Center for Economic Research and Graduate Education (CERGE) and

Economics Institute (EI), Academy of Sciences of the Czech Republic

CERGE-El, Politických vězňů 7, 11121 Prague 1, tel.: +420 224005 153, Czech Republic.

Printed by CERGE-EI, Prague

Subscription: CERGE-EI homepage: http://www.cerge-ei.cz

Editors: Directors of CERGE and EI

Managing editors: Deputy Directors for Research of CERGE and EI

ISSN 1211-3298

ISBN 80-7343-087-8 (Univerzita Karlova v Praze, CERGE)

ISBN 80-7344-076-8 (Národohospodářský ústav AV ČR, Praha) 
CERGE-EI

P.O.BOX 882

Politických vězňů 7

11121 Praha 1

Czech Republic http://www.cerge-ei.cz 